$10 / 95950$
8 SANDIA REPORT

SAND95-8250 •

Unlimited Release

Printed July 1995

\title{
Coal Char Fragmentation During Pulverized Coal Combustion
}

\author{
L. L. Baxter
}

Prepared by

Sandia National Laboratories

Albuquerque, New Mexico 87185 and Livermore, California 94551

for the United States Department of Energy

under Contract DE-AC04-94AL85000

Approved for public release; distribution is unlimited. 
Issued by Sandia National Laboratories, operated for the United States Department of Energy by Sandia Corporation.

NOTICE: This report was prepared as an account of work sponsored by an agency of the United States Government. Neither the United States Government nor any agency thereof, nor any of their employees, nor any of the contractors, subcontractors, or their employees, makes any warranty, express or implied, or assumes any legal liability or responsibility for the accuracy, completeness, or usefulness of any information, apparatus, product, or process disclosed, or represents that its use would not infringe privately owned rights. Reference herein to any specific commercial product, process, or service by trade name, trademark, manufacturer, or otherwise, does not necessarily constitute or imply its endorsement, recommendation, or favoring by the United States Government, any agency thereof or any of their contractors or subconractors. The views and opinions expressed herein do not necessarily state or reflect those of the United States Government, any agency thereof or any of their contractors or subcontractors.

This report has been reproduced from the best available copy.

Available to DOE and DOE contractors from:

Office of Scientific and Technical Information

P. O. Box 62

Oak Ridge, TN 37831

Prices available from (615) 576-8401, FTS 626-8401

Available to the public from:

National Technical Information Service

U.S. Department of Commerce

5285 Port Royal Rd.

Springfield, VA 22161 


\section{DISCLAIMER}

Portions of this document may be illegible in electronic image products. Images are produced from the best available original document. 
UC-1409

SAND95-8250

Unlimited Distribution

Printed July 1995

\title{
COAL AND CHAR FRAGMENTATION DURING PULVERIZED COAL COMBUSTION
}

\author{
Milestone Report
}

Larry L. Baxter

Combustion Research Facility

Sandia National Laboratories

Livermore, CA 94551-0969

\begin{abstract}
A series of investigations of coal and char fragmentation during pulverized coal combustion is reported for a suite of coals ranging in rank from lignite to low-volatile (lv) bituminous coal under combustion conditions similar to those found in commercial-scale boilers. Experimental measurements are described that utilize identical particle sizing characteristics to determine initial and final size distributions. Mechanistic interpretation of the data suggest that coal fragmentation is an insignificant event and that char fragmentation is controlled by char structure. Chars forming cenospheres fragment more extensively than solid chars. Among the chars that fragment, large particles produce more fine material than small particles. In all cases, coal and char fragmentation are seen to be sufficiently minor as to be relatively insignificant factors influencing fly ash size distribution, particle loading, and char burnout.
\end{abstract}

This work was supported by the U.S. Department of Energy, Office of Fossil Energy, Pittsburgh Energy Technology Center, Advanced Research and Technology Development Program. 


\section{Introduction}

Char fragmentation and flyash formation during pulverized-coal combustion impact important aspects of boiler operation including radiative heat transfer, fouling and slagging propensities, and particulate removal efficiency. Flyash that escapes particle cleanup systems constitutes a significant environmental and health hazard and is the focus of substantial legislation and regulation [Wark and Warner, 1981]. These practical, environmental, health, and legal considerations have motivated a number of theoretical and experimental studies of flyash formation.

Reported mechanisms of flyash formation include (1) vaporization and recondensation of volatile components of coal ash [Flagan, 1978; Flagan and Taylor, 1980; Neville, et al., 1980; Neville and Sarofim, 1985; Quann, et al., 1982; Quann, et al., 1990; Quann and Sarofim, 1982; Quann and Sarofim, 1986], (2) fragmentation of ash due to inorganic reaction [Baxter and Mitchell, 1992; Raask, 1984; Raask, 1985], (3) convective transport of ash during rapid organic reaction [Allen and VanderSande, 1984; Baxter, et al., 1994 (to appear)], (4) structural disintegration of chars [Flagan and Sarofim, 1984], (5) shedding of ash material from the surface of chars during combustion [Allen and VanderSande, 1984; Quann, et al., 1982; Quann and Sarofim, 1982], and (6) coalescence of ash within a char particle [Allen and VanderSande, 1984; Baxter, 1992; Quann and Sarofim, 1982].The term fragmentation, as used in this paper, encompasses all mechanisms that produce more than a single ash particle from a char particle and could involve any or all of the above processes.

Several mechanistic details of fragmentation are available in theoretical papers. Statistical studies ranging from number balances [Dunn-Rankin and Kerstein, 1987; Dunn-Rankin and Kerstein, 1988] to percolation models [Kang, et al., 1988; Kang, et al., 1990; Kerstein and Edwards, 1987] describe the transient development of char particle size distributions, often for a series of assumed scenarios of fragmentation. These models vary widely in their level of detail, although none describes all aspects of fragmentation and parameters used in the models do not always lend themselves to experimental measurement. While progress in this area continues, there exist no complete descriptions of fragmentation in the available literature.

Experimental techniques for studying fragmentation include both solidsampling and laserbased, in situ techniques. Typical solid-sampling studies involve size classification of flyash by a cascade of impactors. Feed material and equipment used in these studies range from mechanically classified samples of coal entrained in laminar flow facilities [Quann and Sarofim, 1982] to utility grind coal sampled from boiler ducts [Holve, 1986]. In situ techniques reported in the past [Wibberley and Wall, 1986] have also been used in laminar flow facilities. Results from various experiments appear discrepant when examined superficially. For example, the reported number of flyash particles generated per char particle varies from near one [Holve, 1986; Sarofim, et al., 1977; Wibberley and Wall, 1986] to several tens of thousands [Quann and Sarofim, 1982; Quann and Sarofim, 1986]. As will be illustrated, these discrepancies may be more superficial than actual. None of these investigations used the same analysis technique to characterize both the feed material and the flyash under combustion conditions representative of commercial boilers.

Specific objectives of this investigation are to (1) devise a fragmentation model that is sufficiently complete to analyze data collected from systems using utility grind coal as a feedstock, (2) measure experimentally the initial and final particle size distributions using the same in situ diagnostic and under conditions comparable to commercial scale operation, and (3) combine the theory and experiment to determine the extent of char fragmentation. 
One of the unique aspects of these investigations is the use of the same in situ sizing technique to determine both char and fly ash particle sizes. Experiments are conducted in the Multifuel Combustor (MFC) using utility-grind, pulverized coal in an environment simulating that of a utility-scale boiler. Size distributions are measured immediately after coal devolatilization and at the end of char combustion (greater than $99 \%$ daf burnout as determined from tracer analysis of solid samples).

The extent of char fragmentation, as indicated by the number of fly ash particles formed per char particle, is found to depend on (in order of importance): (1) char structure, (2) initial char particle size, (3) ash content, and (4) mineral grain size distribution. The first three dependencies are clearly indicated by existing data. The fourth is postulated pending further investigation of mineral grain size distributions in these coal samples.

The analysis of the data collected from the MFC is similar to a previously published model of char fragmentation [Baxter, 1992]. This analysis is briefly reviewed here. The experimental design is also briefly reviewed. The bulk of the discussion centers on the results and their implications.

\section{Theoretical Analysis}

The fragmentation model described below relates the initial char (not coal) feedstock and final fly ash size distributions. The model is written in terms that are convenient for laboratory analyses. That is, the char particles have physical properties that can vary as a function of size but, at a given size, are described by a single-valued function. Particle-toparticle variations in physical properties at a given size are neglected. Also, transient developments in particle size distributions, as discussed by many of the previously cited authors, are neglected. Size distributions of the initial char and final fly ash can be related, in general, through a particle number balance.

$$
\int_{d_{a 1}}^{d_{a}} n_{a}^{\prime}(x) d x=\int_{d_{c}=0}^{d_{c}=\infty} \int_{d_{a 1}}^{d_{a}} g(x \mid y) d x n_{c}^{\prime}(y) d y
$$

The functions $n_{a}^{\prime}$ and $n_{c}^{\prime}$ represent particle concentration density functions for fly ash and char, respectively, with typical units of particles $/\left(\mathrm{m}^{3} \mu \mathrm{m}\right)$. Dummy variables $x$ and $y$ are used in the integrands to represent fly ash $\left(d_{a}\right)$ and char $\left(d_{c}\right)$ particle diameters, respectively. Integration of $n^{\prime}$ with respect to particle diameter represents the cumulative concentration of particles with sizes between the limits of integration. Thus, the integral on the left represents the total concentration of fly ash particles with diameters larger than $d_{a 1}$ and smaller than $d_{a}$.

The function $g(x \mid y)$ is a conditional fly ash particle size distribution (psd); it indicates the ultimate size distribution of fly ash particles formed from a char particle with initial size $y$. This represents the only portion of the above equation that is not determined experimentally in this investigation.

Several published theoretical and experimental results suggest general forms of the function. One example [Quann and Sarofim, 1986] provides data from which $g(x \mid y)$ can be 
determined for one char particle size. In that study, coal particles were mechanically sieved to a $140 \mu \mathrm{m}$ nominal diameter and combusted at a particle temperature of about $2000 \mathrm{~K}$ in a $20 \% \mathrm{O}_{2}$ environment. The number of fly ash particles generated was deduced as a function of fly ash particle size.

The function $g(x \mid y)$ for this literature data [Quann and Sarofim, 1986] can be generated by differentiating the cumulative size distribution with respect to particle size. This is illustrated in Figure 1. The linearity of the data when plotted in this way suggests that the the data follow a power-law distribution, i.e.,

$$
g(x \mid y)=\left\{\begin{array}{cc}
a(y) x^{b}, & \text { for } x_{1}(y) \leq x \leq x_{2}(y) \\
0 & \text { otherwise }
\end{array}\right.
$$

where $x_{1}$ and $x_{2}$ represent the diameters of the smallest and largest fly ash particle generated, respectively. This conditional psd describes a power-law size distribution between the limits $x_{1}$ and $x_{2}$ for fly ash particles generated from each char particle of size $y$. Note that this functional form can only describe the results from an ensemble of initial char particles with size $y$. The functional form of $g$ for a single char particle is series of Dirac delta functions.

Values for $a$ and $b$ of 3260 and -3.21 , respectively, fit the literature data [Quann and Sarofim, 1986] with a coefficient of determination [Canavos, 1984] $\left(\mathrm{r}^{2}\right)$ greater than 0.99 (in logarithmic coordinates with $x$ expressed in microns). The original data of Quann and Sarofim have been recast in number density form, and this correlation is compared with these recast data in Figure 1. The authors state that the smallest particles (those smaller than about $0.6 \mu \mathrm{m}$ ) are generated by vaporization-recondensation mechanisms, whereas the larger particles are believed to be generated by surface drop shedding or disintegration of char structures. If the data at sizes smaller than $0.6 \mu \mathrm{m}$ are eliminated, values for $a$ and $b$ of 2370 and -2.95 , respectively, fit the remaining data, also with a coefficient of determination greater than 0.99 . Therefore, the functional form for $g(x \mid y)$ given by Eq. 2 represents at least this set of data regardless of the mechanism of fragmentation and the value of $b$ used in the conditional psd can be assumed to be approximately -3 .

Results of a percolation model of char fragmentation [Dunn-Rankin and Kerstein, 1988] provide further theoretical motivation for this functional form of this conditional pdf. This formulation has been used in other theoretical studies of the transient evolution of char particle size distributions [Kerstein and Edwards, 1987].

A mass balance on the fly ash determines the function $a(y)$, as follows:

$$
m_{a}(y)=\int_{0}^{\infty} \frac{\pi}{6} \rho_{a} x^{3} g(x \mid y) d x=\frac{\pi}{6} \rho_{a} a(y) \Delta x(y)=\omega_{a}(y) m_{c}=\omega_{a}(y) \frac{\pi}{6} \rho_{c} y^{3}(3)
$$

where $\rho$ represents density, $\omega$ represents ash mass fraction, and $\Delta x$ represents $x_{2}-x_{1}$. Note that the density of the initial char particle $\left(\rho_{c}\right)$ represents the density of the total particle, not just the organic portion. Also, the density of the final ash particle and the ash mass fraction 
in the char particle ( $\rho_{a}$ and $\omega_{a}$, respectively) represent values of $a s h$, as opposed to the mineral matter from which the ash is formed. It follows from Eq. 3 that,

$$
a(y)=\frac{\omega_{a}(y) \rho_{c} y^{3}}{\rho_{a} \Delta x(y)}
$$

For convenience in determining the upper and lower bounds of $g$, a parametric function $f(y)$ is designated the fragmentation factor and is defined as follows:

$$
f(y) \equiv \frac{\left(\omega_{a} \rho_{c} / \rho_{a}\right)^{1 / 3} y}{x_{2}}
$$

The numerator represents the size of the fly ash particle that obtains when all of the ash in a char particle coalesces, i.e., no fragmentation occurs. The function $f$ equals the ratio of this hypothetical size to the size of the largest fragment actually generated from a char particle $\left(x_{2}\right)$; $f$ increases with an increase in the extent of fragmentation. In the limit of no fragmentation, $f$ is unity, independent of either initial char particle size $(y)$ or char size

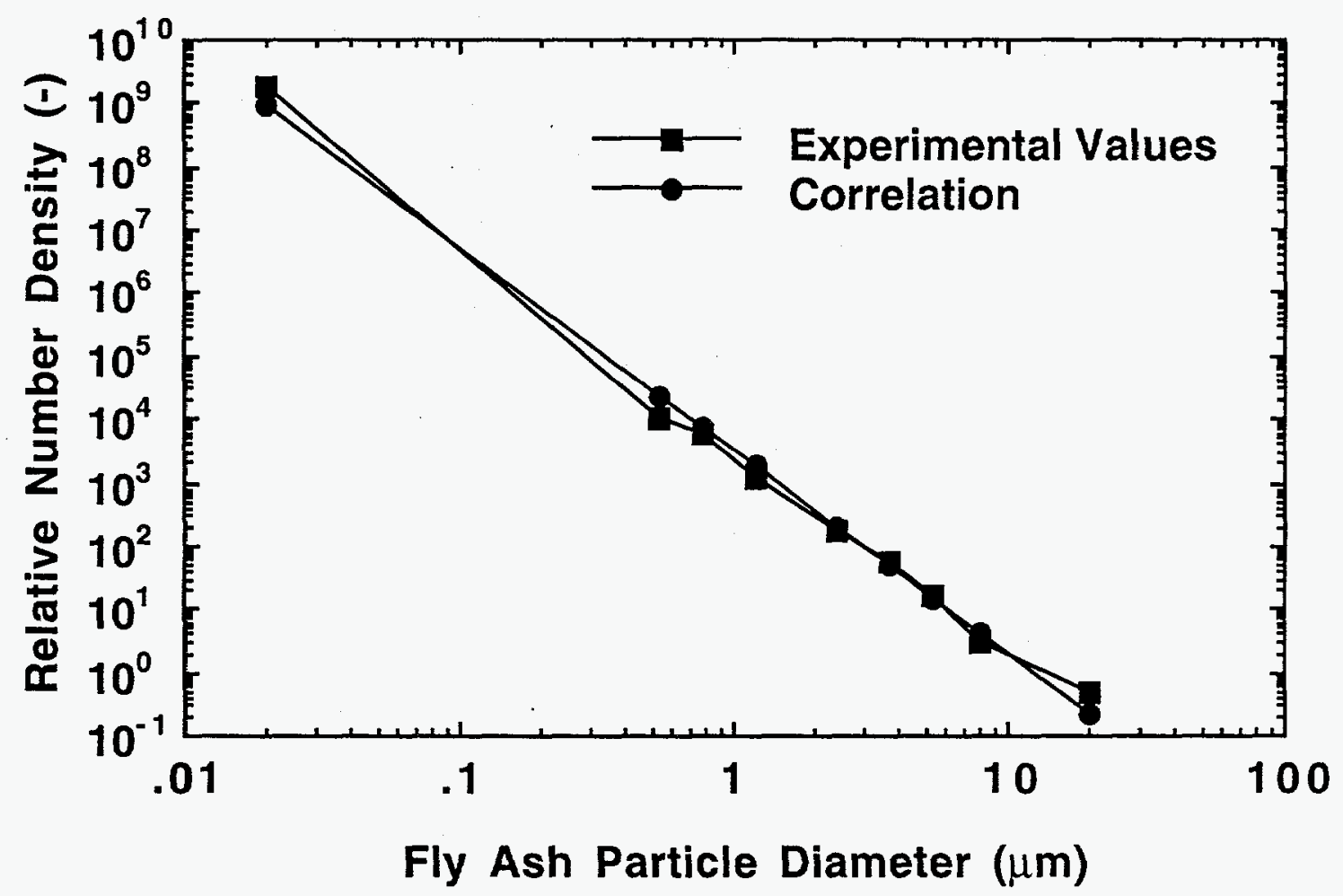

Figure 1. Power law function $g(x \mid y)$ correlated with the power-law size distribution. Data are from the literature [Quann and Sarofim, 1986]. 
dependencies in either $\rho$ or $\omega$. (This statement may appear to contradict the explicit dependence of $f$ on $y$ indicated in Eq. 5. However, in the case of no fragmentation, this explicit dependence cancels with the implied dependence of $x_{2}$ and of the physical properties on $y$.) In general, $f$ is expected to be greater than or equal to 1 . The parameter $f$ indicates the extent of fragmentation in that it increases as the extent of fragmentation increases. If char were to produce a monodispersion of fly ash particles as a consequence of fragmentation, the total number of fragments produced would be equal to $f^{3}$.

A second function $s(y)$, designated the fragment size ratio, is defined as

$$
s(y) \equiv \frac{x_{1}(y)}{x_{2}(y)}
$$

and represents the mode of fragmentation in the sense that $s$ decreases as the range of fragment sizes produced from a char particle increases. If there is no fragmentation, both $f$ and $s$ are unity. As $s$ decreases from unity toward zero, the range of sizes of fragments produced from a single char particle increases.

Equation 2 can be written in terms of the parameters $f$ and $s$ as

$$
g(x \mid y)=\left\{\begin{array}{cc}
\frac{\omega_{a} \rho_{c} y^{3}}{\rho_{c} \Delta x} x^{-3} \text { for } & x_{1}(y) \leq x \leq x_{2}(y) \\
0 & \text { otherwise }
\end{array}\right.
$$

yielding

$$
\begin{gathered}
\int_{d_{a 1}}^{d_{a}} g(x \mid y) d x=\frac{f^{3}}{2}\left(\frac{1-s^{2}}{s^{2}-s^{3}}\right)+\min \left\{\frac{f^{3}}{2(1-s)}\left[\left(\frac{x_{2}}{\min \left(x_{2}, d_{a 1}\right)}\right)^{2}-\left(\frac{1}{s}\right)^{2}\right], 0\right\}+ \\
\min \left\{\frac{f^{3}}{2(1-s)}\left[1-\left(\frac{x_{2}}{\max \left(x_{1}, d_{a}\right)}\right)^{2}\right], 0\right\}
\end{gathered}
$$

where $s, f$ and $x_{2}$ depend on $y$. The second term on the right side is negative for all $y$ where $d_{a 1}>x_{1}$ and the third term is negative for $d_{a}<x_{2}$. Otherwise, both terms are zero. If all particle sizes are included in the integration $\left(d_{a 1}=0\right.$ and $d_{a}$ larger than the largest char or fly ash particle in the stream), the only nonzero term on the right side of the equation is the first term, which represents the ratio of the total numbers of fly ash and char particles.

In general, both $f$ and $s$ depend on initial char particle size $y$. However, the qualitative relationship between initial char and fly ash particle size distributions is conveniently illustrated by assuming that $f, s$ and the ratio $\left(\omega_{a} \rho_{c}\right) / \rho_{a}$ are independent of initial char particle size and can be treated with average values. This means the char particles are homogeneous, or size-invariant, with respect to both their physical properties and their 
In general, both $f$ and $s$ depend on initial char particle size $y$. However, the qualitative relationship between initial char and fly ash particle size distributions is conveniently illustrated by assuming that $f, s$ and the ratio $\left(\omega_{a} \rho_{c}\right) / \rho_{a}$ are independent of initial char particle size and can be treated with average values. This means the char particles are homogeneous, or size-invariant, with respect to both their physical properties and their fragmentation properties and that the behavior of particles in a given size range can be represented by statistical averages of properties. Under these assumptions,

$$
x_{2}=\left(\frac{\omega_{a} \rho_{c}}{\rho_{a}}\right)^{1 / 3} \frac{y}{f} \equiv p y
$$

and

$$
x_{1}=s x_{2}=p s y
$$

where $p$ is independent of $y$ and typically has a value of order 0.5 or less. This allows the integral of the conditional psd to be expressed analytically in terms of $y$ only. If all ash particles are included in the integration $\left(d_{a 1}=0\right)$, the relationship between char and fly ash concentration distributions can be written as

$$
\int_{0}^{d_{a}} n_{a}^{\prime}(x) d x=\int_{0}^{d_{a} /(p s)} n_{c}^{\prime}(y) \frac{f^{3}}{2}\left(\frac{1-s^{2}}{s^{2}-s^{3}}\right) d y+\int_{d_{a} / p}^{d_{a} /(\rho s)} n_{c}^{\prime}(y) \frac{f^{3}}{2(1-s)}\left[1-\left(\frac{p y}{d^{2}}\right)^{2}\right] d y
$$

A linear transformation of this equation relates directly to the experimentally measured cumulative particle size distributions reported later. This transformed expression is

$$
K_{a}(d) \equiv \int_{d}^{\infty} n_{a}^{\prime}(x) d x=\int_{0}^{\infty} n_{a}^{\prime}(x) d x-\int_{0}^{d} n_{a}^{\prime}(x) d x
$$

where the integral from 0 to $\infty$ is a constant (independent of $d_{a}$ ). A similar expression defines the function $K_{c}$ for the char particles.

$$
K_{c}(d) \equiv \int_{d}^{\infty} n_{c}^{\prime}(x) d x=\int_{0}^{\infty} n_{c}^{\prime}(x) d x-\int_{0}^{d} n_{c}^{\prime}(x) d x
$$


Limiting forms of Eq.1, other than Eq. 11, are useful to consider. If the initial char particles are monodisperse ( $n_{c}^{\prime}$ is a Dircac delta function), the integral on the left represents the total number of fly ash particles produced per char particle. Assuming Eq. 2 as the appropriate description for $g$, the total number of fly ash particles generated per char particle becomes

$$
g=\frac{f^{3}}{2}\left(\frac{1+s}{s^{2}}\right)
$$

Eq. 14 indicates the dependence of the number of fly ash particles on the parameters $f$ and $s$. For a given value of $f$, the number of fly ash particles increases dramatically as $s$ decreases (recall that $s$ is always less than or equal to 1 ). Similarly, as $f$ increases for a given value of $s$, the total number of fly ash particles increases as $f^{3}$.

The valid range of the functions $f$ and $s$ illustrate that this theoretical approach is applicable only to ensembles of particles, not to individual particles. For example, when the ash in an individual particle coalesces to form a single fly ash particle $(f=1)$, there is only one size fly ash particle produced $(s=1)$. However, only a fraction of the particles in an ensemble of nominally identical char particles may behave this way. Therefore, $f$ can assume a value of unity for the ensemble without limiting the range of values $s$ can assume. In the application of this theory in this work, the only theoretical limitations on these two parameters are that $f \geq 1$ and $s \leq 1$. The functions are independent of each other.

\section{Experimental Conditions}

The Multifuel Combustor (MFC) (Fig. 2) and a Particle Counter Sizer Velocimeter (PCSV) are the primary experimental facility and diagnostic, respectively, used in this work. The MFC provides careful control of gas temperature and composition in a long-residence-time facility. The MFC was operated at a firing rate of $0.07 \mathrm{MBtu} / \mathrm{hr}$ with overall oxygen concentrations varying from 5 to 3 mole $\%$ during char oxidation, conditions similar to commercial-scale boiler operation. Particle residence time is varied by moving the location of the coal injection lance to various ports along the length of the combustor.

The PCSV performs in situ measurements of particle frequency (count), size and speed at the base of the combustor. The PCSV is based on near-forward light scattering from laser beams focused at the center of the reactor flow. Two laser beams are used, one for large particles $(>3 \mu \mathrm{m})$ and the second for small particles. The measurements are based on individual particles passing through an approximately ellipsoidal diagnostic volume with a major axis of about $1 \mathrm{~mm}$ and minor axes of approximately $300 \mu \mathrm{m}$ for one beam and 50 $\mu \mathrm{m}$ for the second. The diagnostic is discussed more fully in the literature [Holve and Self, 1979a; Holve and Self, 1979b; Holve, et al., 1981].

The accuracy of the instrument is verified by passing monosized standards through the diagnostic volume and comparing the measured particle sizes with the known actual sizes. Standards used included glass beads entrained in air and transparent discs etched in an opaque reticule. The standards varied from 0.6 to $60 \mu \mathrm{m}$ and indicate that the PCSV reports particle sizes within one size bin or $0.1 \mu \mathrm{m}$ of the correct size, whichever is larger. 


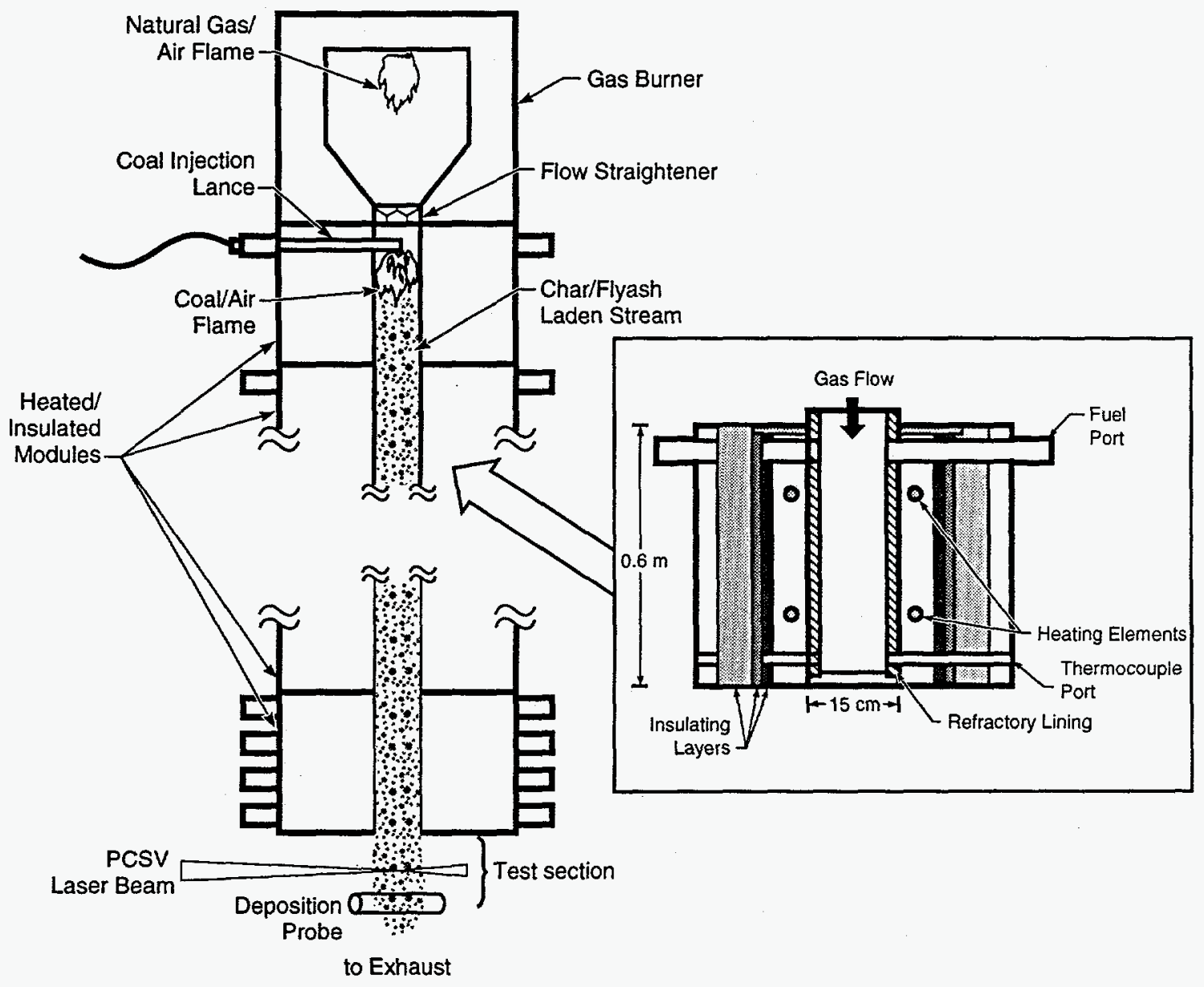

Figure 2. Schematic diagram of the Sandia Multifuel Combustor. The laser beam from the PCSV particle sizing system is illustrated in the test section of the combustor.

The precision of the data is determined by repeating measurements of coal and fly ash in the MFC under nominally identical conditions and computing coefficients of variation from the results. At least five, and as many as twelve, replicate experiments were performed for each coal at each sampling height. The coefficient of variation thus determined includes experimental uncertainty as well as actual fluctuations due, for example, to turbulent fluctuations and variations in coal feed rates. The impact of such fluctuations on the data can be minimized by computing the total mass flowrate from the measured particle concentrations and normalizing all the results to this value. Confidence intervals presented below are based on these measured coefficients of variation and standard statistical techniques.

The upper and lower detection limits of the PCSV are determined in these experiments by the points at which the agreement among the repeated tests becomes poor, as indicated by 
the statistical confidence intervals. The lower limit is $0.4-0.7 \mu \mathrm{m}$ and is controlled primarily by signal-to-noise levels in the detector. The upper limit is controlled by sampling statistics in this experiment. Approximately 160,000 individual particles were sampled per measurement, and each measurement was repeated 5 to 12 times. Under these conditions, the upper detection limit is about $100 \mu \mathrm{m}$.

Reasonably complete analyses of all the coals used in these experiments are included in the appendix. The data in the appendix include all of the coals used in the program to date. There are several samples of coal with the same name. These are distinguished by numbers, for example, Illinois \#6 (2) is a different coal sample than Illinois \#6 (1).

The nominal conditions under which these experiments were conducted are summarized in Table 1. Under these experimental conditions, the particles form a dilute phase in the gas, with the total particle volume fraction far less than one percent of the overall gas volume. Consequentially, the probability of particle-particle collisions producing agglomerated fly ash is vanishingly small.

\section{Coals and Coal Properties}

Table 2 summarizes the properties of the coals whose fragmentation rates were studied. The coals span a range of rank from lignite to low-volatile bituminous and a range of ash concentrations from 2.8 to $52 \%$, with an average value of sligthly greater than $10 \%$. Representatives from essentially every commercially significant coal-producing region of the country are included among the coals studied. More complete analyses of the coals are provided in Appendix A. These analyses include: (1) moisture content; (2) proximate analysis; (3) ultimate analysis; (4) ash chemistry; (5) ash fusion temperatures under reducing and oxidizing environments; (6) sulfur forms; (7) particle size distributions determined by sieves; (8) particle size distributions determined by Malvern optical analyses, (9) chlorine content (for coals containing appreciable chlorine), and (10) heating value. In all cases, the data are averages of several replicated measurements.

\section{Table 1}

\section{Typical Local Gas and Particle Properties in the MFC at the Initial Char and the Fly Ash Measurement Locations}

$\begin{array}{lcc}\text { Property } & \text { Initial Char } & \text { Fly Ash } \\ \text { Gas temperature }\left({ }^{\circ} \mathrm{C}\right) & 1100 & 900 \\ \text { Oxygen mole fraction } & 0.06 & 0.04 \\ \text { Particle residence time } \tau(\mathrm{s}) & 0.2 & 2.1 \\ \text { Particle burnout (daf) } & 0.65 & 0.99+ \\ \text { Particle temperature }\left({ }^{\circ} \mathrm{C}\right) & 1250 & 900\end{array}$

Fragmentation data for all of the coals are available. There is a great deal of similarity and consistency among the data for similar coals. Representative results illustrating trends with initial particle size, ash loading, coal type, and char structure are presented here. In the discussion below, we focus upon the important trends observed in these collections of data. 
Table 2

Characteristics of utility-grind coals studied during this investigation.

\begin{tabular}{|c|c|c|c|c|c|}
\hline Coal & $\begin{array}{c}\text { Fixed } \\
\text { Carbon } \\
{[-]}\end{array}$ & $\begin{array}{c}\text { arr Value } \\
\text { Volatile } \\
\text { Matter } \\
{[-]}\end{array}$ & $\begin{array}{l}\text { Heating } \\
\text { Value } \\
\text { Btu/lb }\end{array}$ & $\begin{array}{l}\text { Ash } \dagger \\
{[-]}\end{array}$ & Rank \\
\hline Pocahantas \#3 (1) & 85.8 & 14.2 & 15712 & 7.1 & lv Bituminous \\
\hline Upper Freeport $¥$ & 71.45 & 28.55 & 15342 & 21.66 & mv Bituminous \\
\hline Mingo Logan & 64.18 & 35.82 & 15141 & 9.34 & hv A Bituminous \\
\hline Pittsburgh-Seam & 59.01 & 40.99 & 15154 & 8.40 & hv A Bituminous \\
\hline Illinois \#6 (3) & 57.32 & 42.68 & 15023 & 5.62 & hv A Bituminous \\
\hline Pittsburgh \#8 (2) & 61.51 & 38.49 & 14843 & 6.55 & hv A Bituminous \\
\hline Massey Sprouce & 62.85 & 37.15 & 14786 & 8.33 & hv A Bituminous \\
\hline Eastern Kentucky & 59.76 & 40.24 & 14724 & 10.15 & hv A Bituminous \\
\hline Pittsburgh \#8 (1) & 56.44 & 43.56 & 14695 & 10.68 & hv A Bituminous \\
\hline Utah Blind Canyon & 51.92 & 48.08 & 14276 & 10.40 & hv A Bituminous \\
\hline Kentucky \#11 & 57.38 & 42.62 & 13269 & 22.21 & hv B Bituminous \\
\hline Illinois \#6 (2) & 56.34 & 43.66 & 13083 & 12.33 & hv B Bituminous \\
\hline SOAP§ & 57.6 & 42.4 & 12900 & 2.8 & hv C Bituminous \\
\hline Kentucky \#9¥ & 57.15 & 42.85 & 12791 & 14.64 & hv C Bituminous \\
\hline Hanna Basin & 57.59 & 42.41 & 12053 & 11.05 & hv C Bituminous \\
\hline Illinois \#6 $(1)^{¥}$ & 55.68 & 44.32 & 11997 & 10.13 & hv C Bituminous \\
\hline Roland-Seam & 52.85 & 47.15 & 11494 & 6.29 & Subbituminous A \\
\hline Decker & 53.92 & 46.08 & 10726 & 5.11 & Subbituminous A \\
\hline Black Thunder & 42.27 & 57.73 & 10675 & 6.46 & Subbituminous A \\
\hline Belle Ayr & 49.02 & 50.98 & 10130 & 6.04 & Subbituminous $\mathrm{B}$ \\
\hline Wyodak & 51.79 & 48.21 & 10059 & 6.22 & Subbituminous B \\
\hline Antelope & 54.53 & 45.47 & 9918 & 5.51 & Subbituminous B \\
\hline Eagle Butte $¥$ & 51.68 & 48.32 & 9286 & 6.40 & Subbituminous C \\
\hline Beulah Lignite $¥$ & 51.28 & 48.72 & 8202 & 13.86 & Lignite A \\
\hline Texas Lignite $¥$ & 39.98 & 60.02 & 7513 & 51.96 & Lignite A \\
\hline \multicolumn{6}{|c|}{ Blends } \\
\hline Eastern Blend & 67.77 & 32.23 & 15312 & $\overline{8.67}$ & hv A Bituminous \\
\hline Pitt. \#8/Decker & 61.3 & 38.7 & 13599 & 6.96 & hv B Bituminous \\
\hline NIPSCO Belnd (1) & 54.3 & 45.7 & 12786 & 7.71 & hv C Bituminous \\
\hline NIPSCO Blend (2) & 53.26 & 46.74 & 12742 & 7.80 & hv C Bituminous \\
\hline Roland/Mlinois \#6 & 54.3 & 45.7 & 12467 & 8.97 & hv C Bituminous \\
\hline Eagle Butte/Ken. \#9 & 51.3 & 48.7 & 10592 & 9.39 & Subbituminous A \\
\hline \multicolumn{6}{|c|}{$\begin{array}{l}\text { Fixed carbon and volatile matter are on dry, mineral-free (as opposed to ash- } \\
\text { free) basis. Heating value is on a moist, mineral-free basis. } \\
\text { Ash is on a dry basis. } \\
\$ \text { Spherical Oil Agglomeration Product derived from an Illinois \#6 coal. } \\
\text { Coals obtained from PSIT as part of the original suite used in their mineral } \\
\text { investigations. }\end{array}$} \\
\hline
\end{tabular}




\section{Experimental Results and Discussion}

\section{Coal Fragmentation}

Coal fragmentation (as opposed to char fragmentation) could be effected by rapid mass loss during devolatilization. The extent of coal fragmenation was analyzed in this study by comparing coal particle size probability density functions with those for char particles after devolatilization. Figure 3 illustrates cummulative particle size distribution (pdf) data for the Kentucky \#9 coal. Data of these type are often presented in a histogram format. All data in this report are persented on a pdf basis. The difference can be quite large. The historgram format presents the fraction of the total data contained within some range, for example, the mass fraction of particles with sizes between two limits. The value of the ordinate is usually dimensionless, because the mass fraction is dimensionless, and changes with changes in the range of the data.

\section{Char Fragmentation}

Data derived from many coals are presented below. The discussion will first contrast a typical swelling coal (Pittsburgh \#8) and a non-swelling coal (Roland coal). Results from the remainder of the coals will be presented in the context of the results from these two coals and will be shown to be consistent in their interpretation.

Cumulative size distributions for char and fly ash particles generated from the Pittsburgh \#8 (2) coal are illustrated in of Fig. 3a. The mean value of the several measured distributions is indicated together with $95 \%$ confidence intervals. The coefficients of variation (standard deviation divided by mean) used in computing the confidence intervals are illustrated as a function of particle size in Fig. 3b. These experimentally determined coefficients of variation are largest at small particle sizes. Light scattering intensity is lowest for small particles and is most influenced by experimental error (detector noise, beam steering, etc.), giving rise to higher coefficients of variation.

The data illustrated in Fig. 3 are representative of all of the coals studied. Only the final results of the fragmentation analysis will be presented for the remainder of the coals studied.

The confidence intervals are largest for the submicron-sized char particles. These, however, are of little consequence to the analysis since they form fly ash particles too small to reliably detect with this technique. Over the range of char and fly ash particle sizes of interest in this study, the size distributions are determined within approximately \pm 20 relative percent accuracy. The confidence intervals are much smaller over most of the range of interest.

Using these data, the fragmentation factor $f$ is computed according to the equations indicated in the preceding discussion. The only quantity not determined from the measurements is $s$. Figure 4a illustrates the computed value of $f$ for an assumed value of $s$ of unity. This is equivalent to assuming that equal-sized fly ash particles form from a char particle of a given initial size. While this assumption is probably not realistic, it is convenient for engineering models (such as ADLVIC) that incorporate fragmentation behavior. 

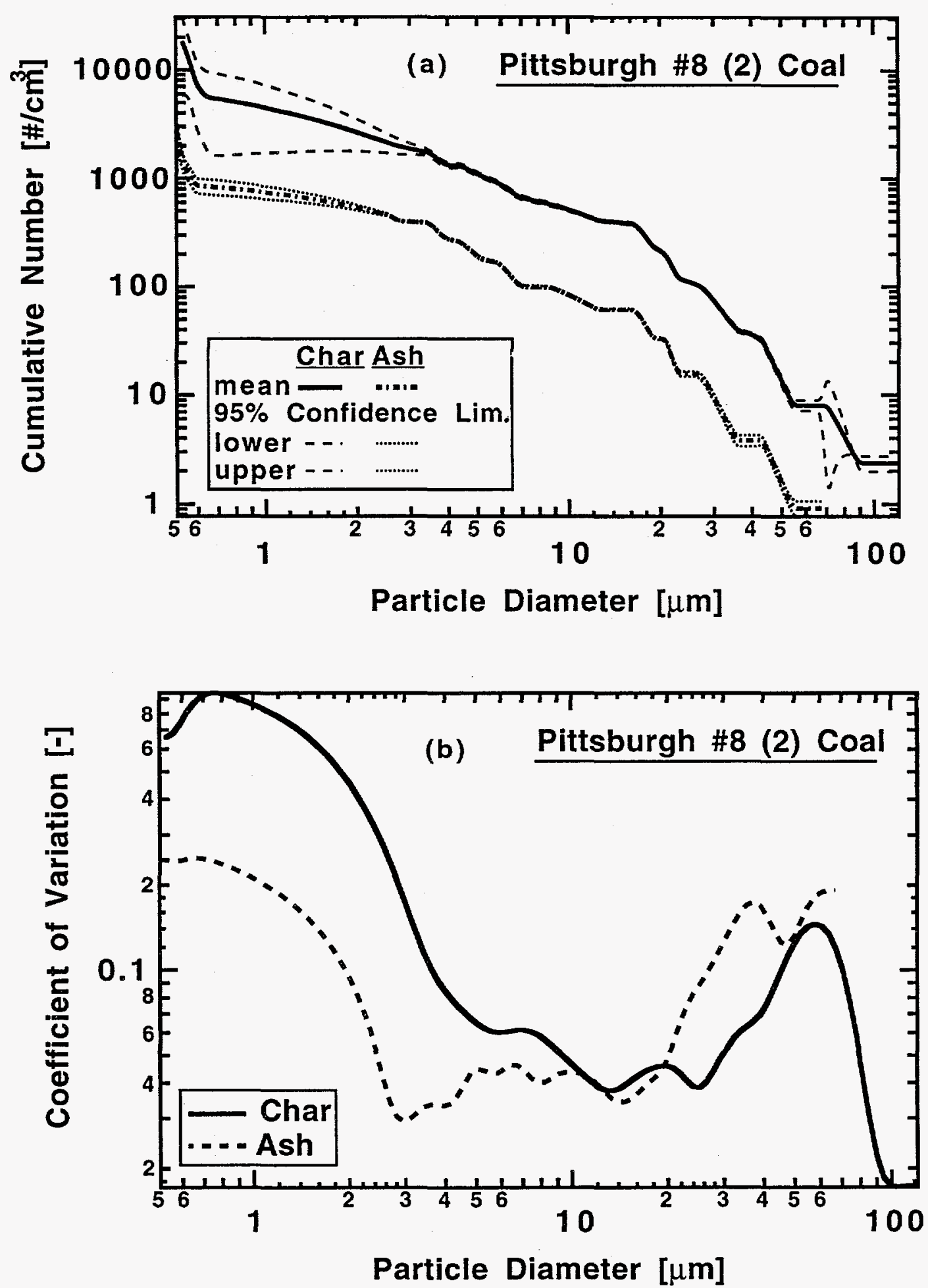

Figure 3. Cumulative particle size distributions and statistics for char and fly ash generated from the Pittsburgh \#8 (2) hv A bituminous coal. 
As illustrated in Fig. 4a, the value of the fragmentation factor exceeds unity only for initial char particle sizes larger than about $20 \mu \mathrm{m}$. The size of fragments generated by the fragmentation of these large particles is indicated by the second abscissa at the top of the figure. Fly ash particles generated through fragmentation are concentrated in the $10 \mu \mathrm{m}$ size range.

The fragmentation factor should range from 1 to larger values, as can be seen from its definition (Eq. 5). The experimental measurements indicate a fragmentation factor as low as 0.7 in some regions of char and fly ash sizes. This is probably associated with variations in the char density and ash mass fraction and the fly ash density as a function of particle size. Reliable information concerning the particle size variation of these physical properties is not available for this coal. Therefore, the properties were assumed to be equal to their average values at all particle sizes. Considering that the fragmentation factor is derived entirely from experimental data, this small deviation of the experimental value below its theoretical limit is viewed as only a minor concern in these results.

Results from similar measurements and analyses for a Roland-seam coal are illustrated in Fig. 5. The ordinates of the two panels in Fig. 5 are scaled the same as those in Fig. 4 to allow a direct comparison. The lower-rank Roland coal is seen to fragment less extensively than the Pittsburgh \#8 bituminous coal. This is consistent with our previous results and with the postulate that fragmentation is strongly influenced by char structure [Baxter, 1992]. Coals that form chars that are cenospheres or 'mesospheres' (have very large voids) are more likely to fragment because they have inherently unstable structures as they burn out. Such is the case with high volatile bituminous coals. Chars that do not form cenospheres, such as the Roland coal, are stable as the char particles burn out. The fragmentation data reflect the stability of the char structure in that there are few fragments formed per original char particle.

The comparison of the Pittsburgh \#8 and Roland coals is representative of all of the coals we have tested. Data for additional coals and coal blends are illustrated in Figures 6 through 10. These data are consistent with earlier observations, i.e., the extent of fragmentation generally increases with increasing char particle size, is greater for chars that form cenospheres than for more dense chars, and decreases with increasing ash loading. While these general characteristics are consistent among all of the data, some details of the data that need further explanation.

Data for the Utah Blind Canyon coal, which is borderline between hv A and hv B bituminous, indicate little fragmentation at any particle size, much the same as the Roland and other subbituminous coals and lignites examined. When compared to the other bituminous coals, the behavior of the Blind Canyon coal appears anomalous. This is only an apparent anomaly, as can be verified by a more detailed investigation of the chemistry of the Utah Blind Canyon coal.

Figure 11 indicates the detailed chemical structure of coals from many of the same seams used in this experiments, including the Blind Canyon coal. These data are taken from published NMR spectroscopy results [Solum, et al., 1989], for coals obtained from the Argonne premium coal bank, not the samples of the coals tested here. The Blind Canyon coal in the Argonne coal bank is chemically more similar to the lower-rank subbituminous coals and lignite than it is to even to the hv B bituminous samples. There are no samples of hv $\mathrm{C}$ available for comparison with these data. We postulate this chemical difference is the reason for the different fragmentation behavior. Coal rank is based solely on heating value and moisture content for these coals (as determined by ASTM D388-36) and is only a crude indicator of the actual chemical structure of the raw coal. 
Fly Ash Diameter [ $\mu \mathrm{m}]$
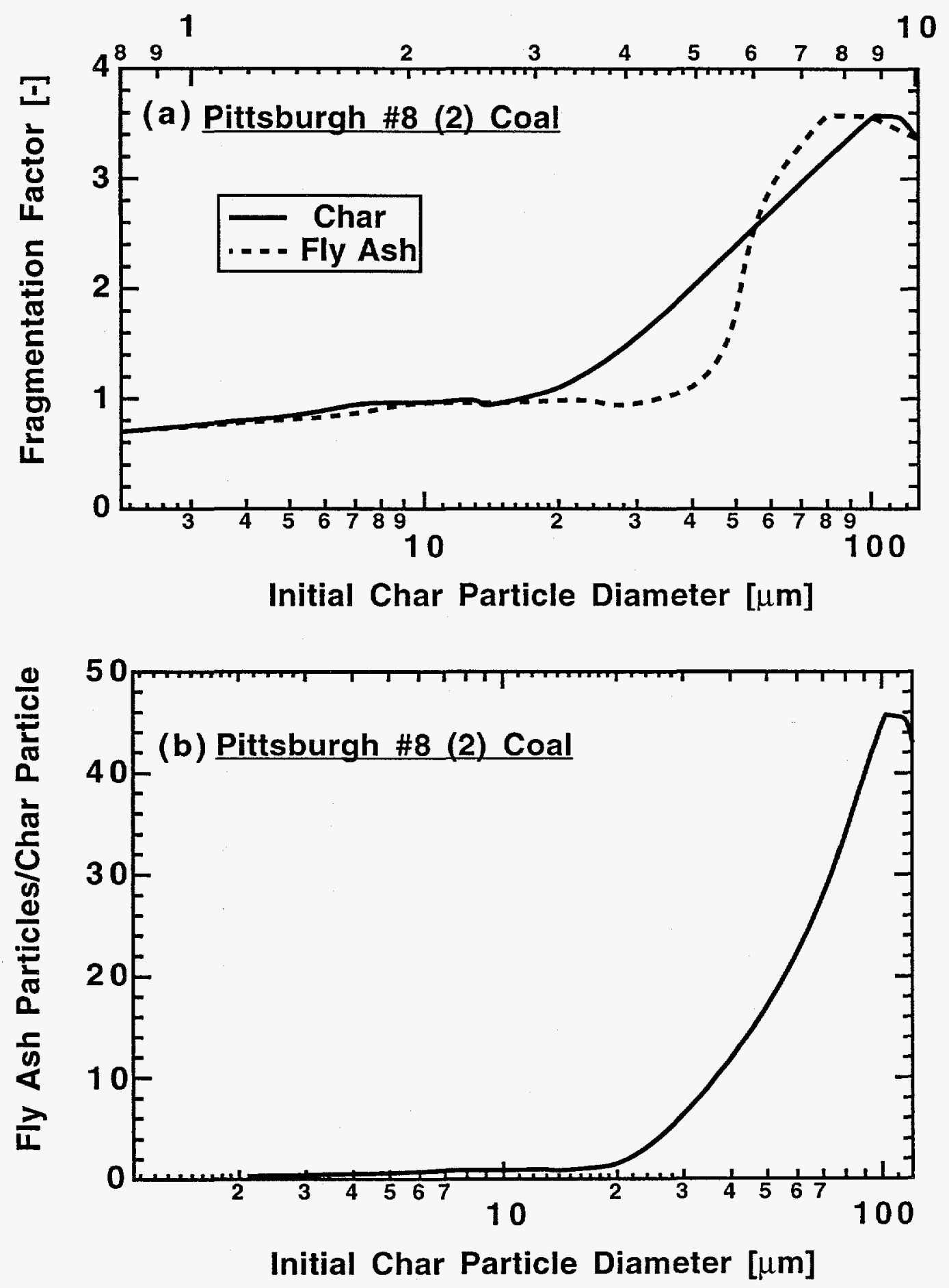

Figure 4. Variation of the fragmentation factor with initial char particle size and fly ash size (a) and the number of fly ash particles formed per char particle as a function of initial char particle size (b) for the Pittsburgh \#8 hv A bituminous coal. 
Fly Ash Diameter $[\mu \mathrm{m}]$
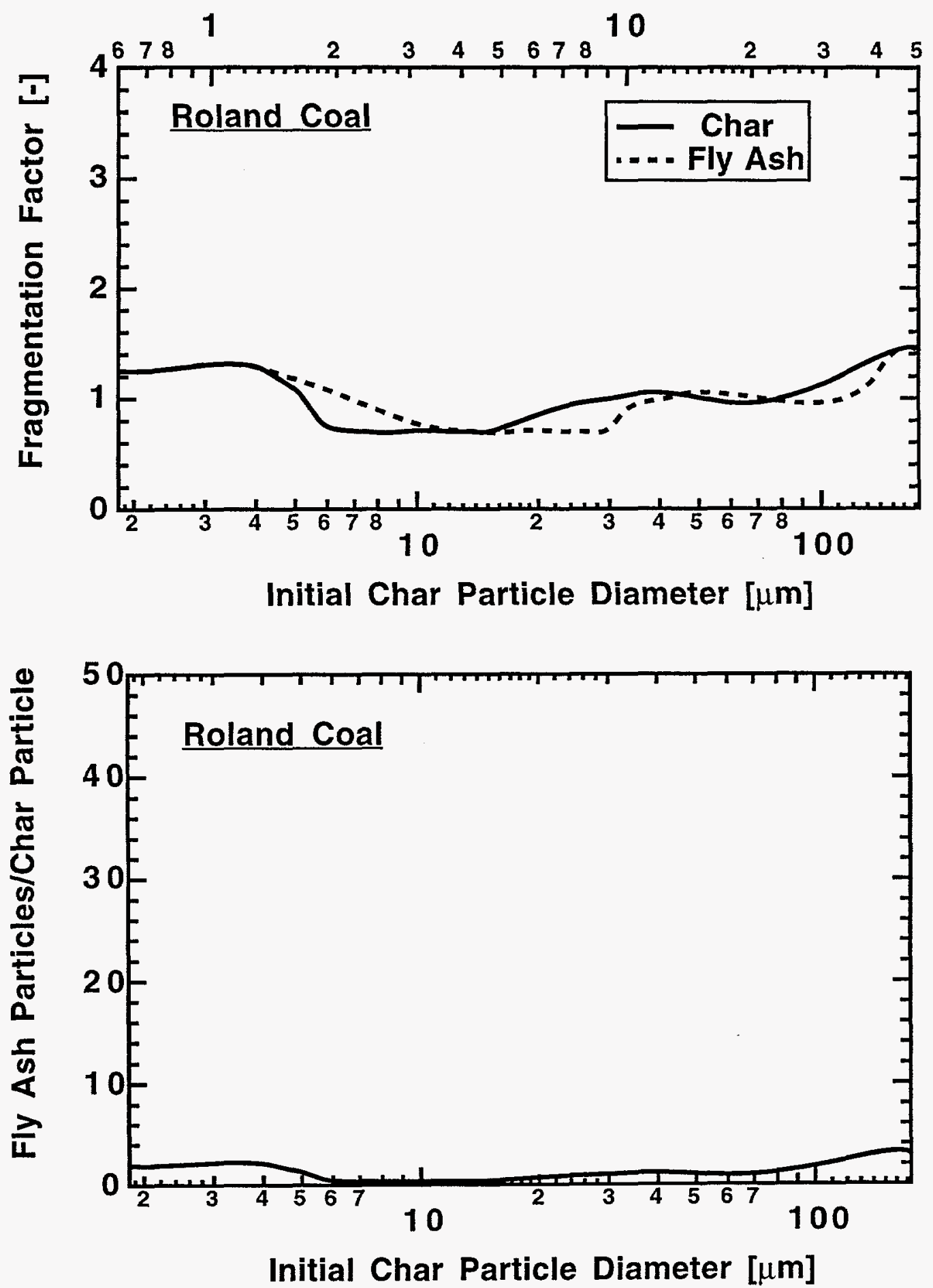

Figure 5. Variation of the fragmentation factor as a function of initial char and final fly ash particles sizes (a) and of the number of fly ash particles produced per char particle as a function of initial char particle size (b) for a Roland-seam subbituminous coal. 
Fly Ash Diameter [um]
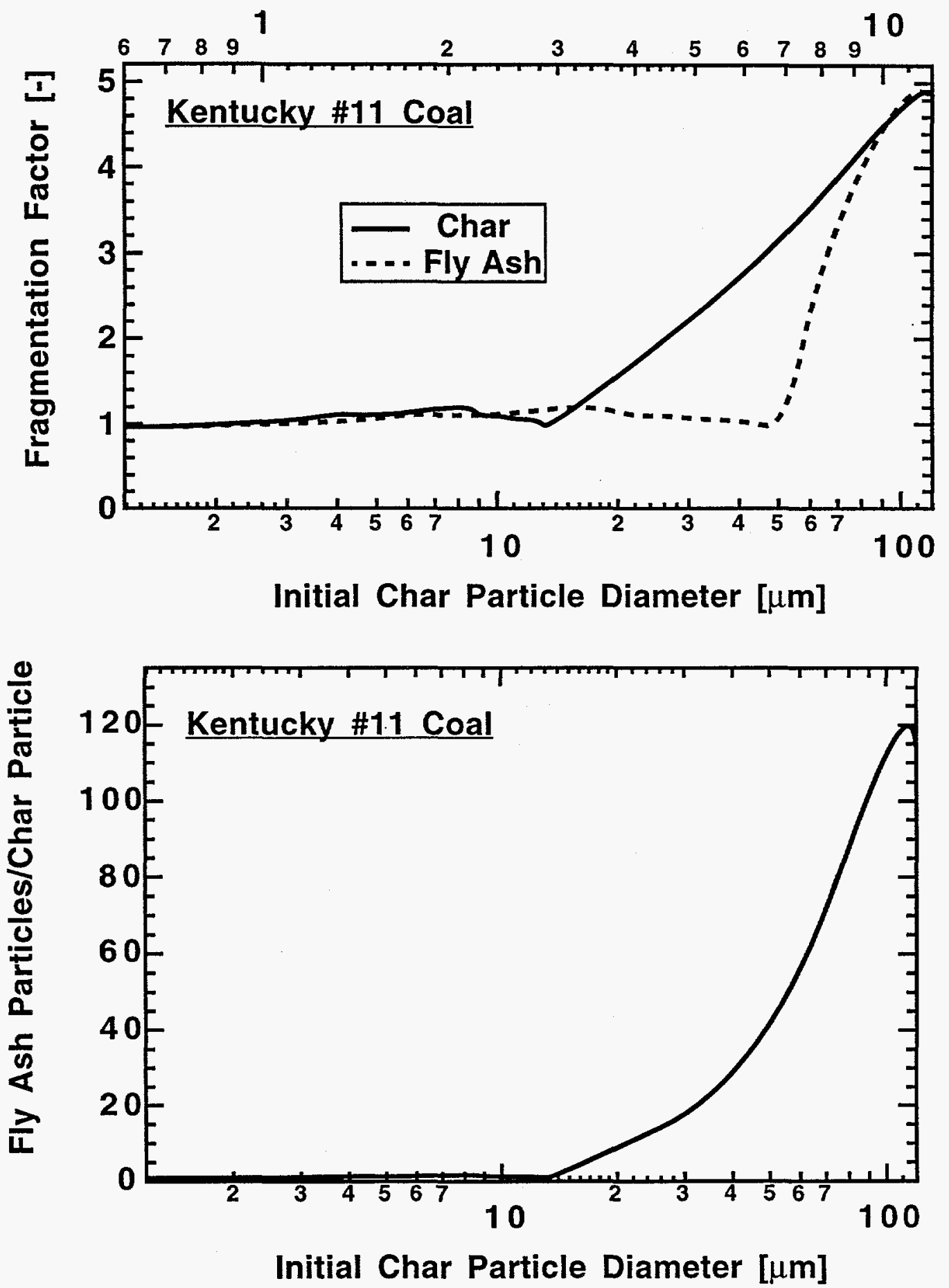

Figure 6. Variation of the fragmentation factor as a function of initial char and final fly ash particle sizes (a) and of the number of fly ash particles produced per char particle as a function of initial char particle size (b) for a Kentucky \#11 hv B bituminous coal. 


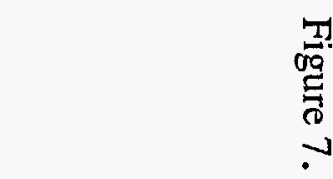

Fly Ash Particles/Char Particle

Fragmentation Factor [-]

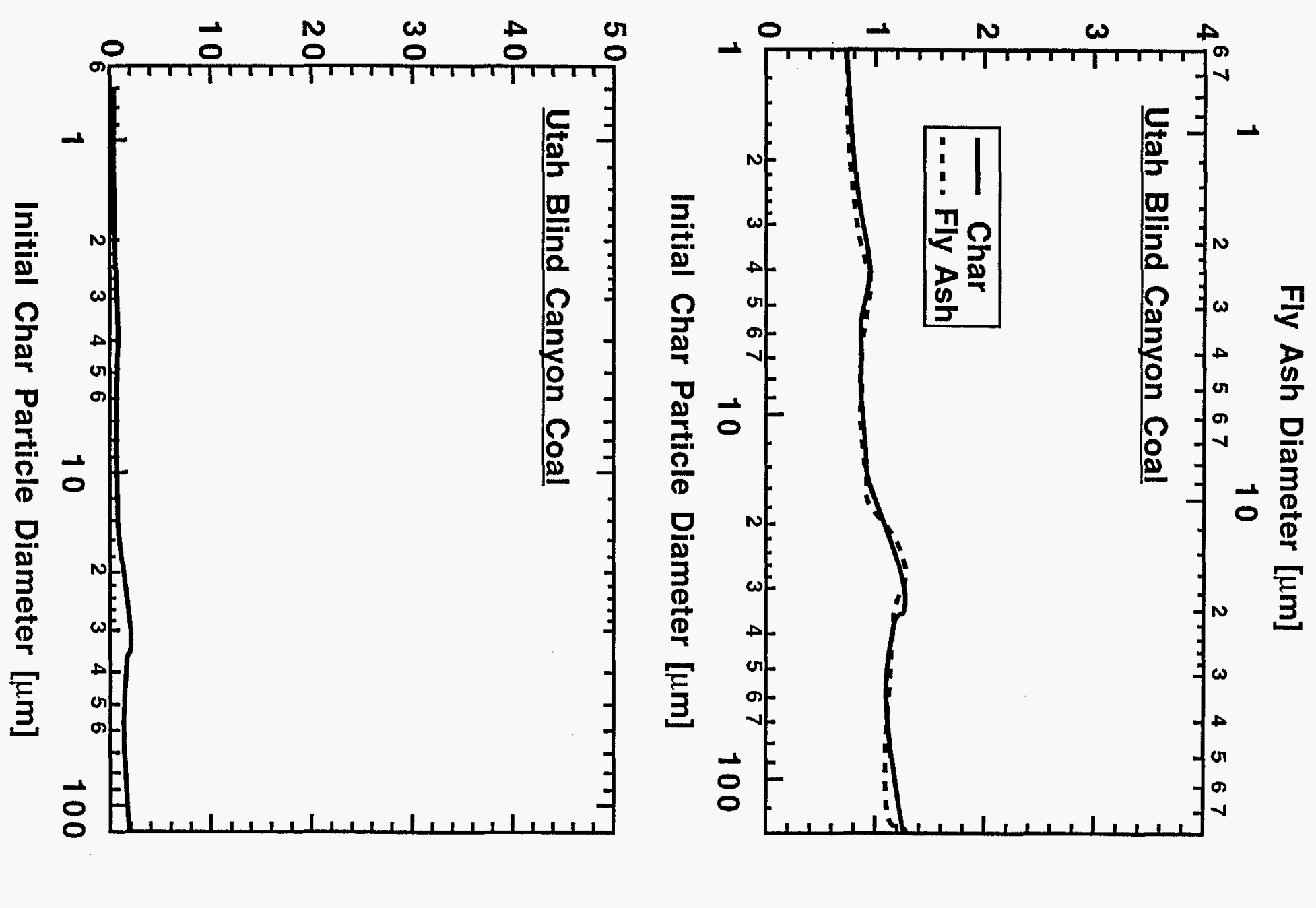


Fly Ash Diameter $[\mu \mathrm{m}]$
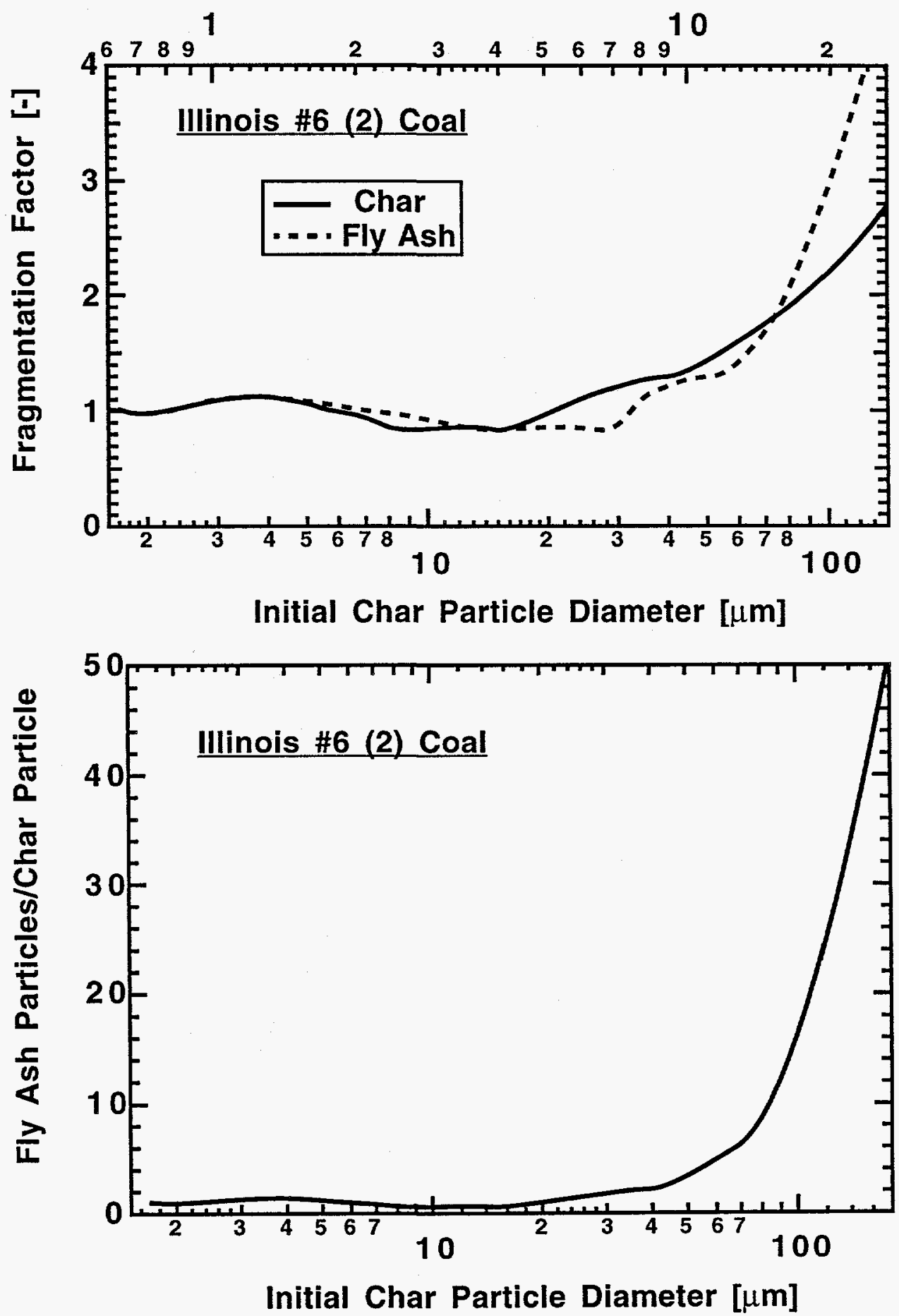

Figure 8. Variation of the fragmentation factor as a function of initial char and final fly ash particle sizes (a) and of the number of fly ash particles produced per char particle as a function of initial char particle size (b) for the Illinois \#6 (2) hv B bituminous coal. 
Fly Ash Diameter $[\mu \mathrm{m}]$
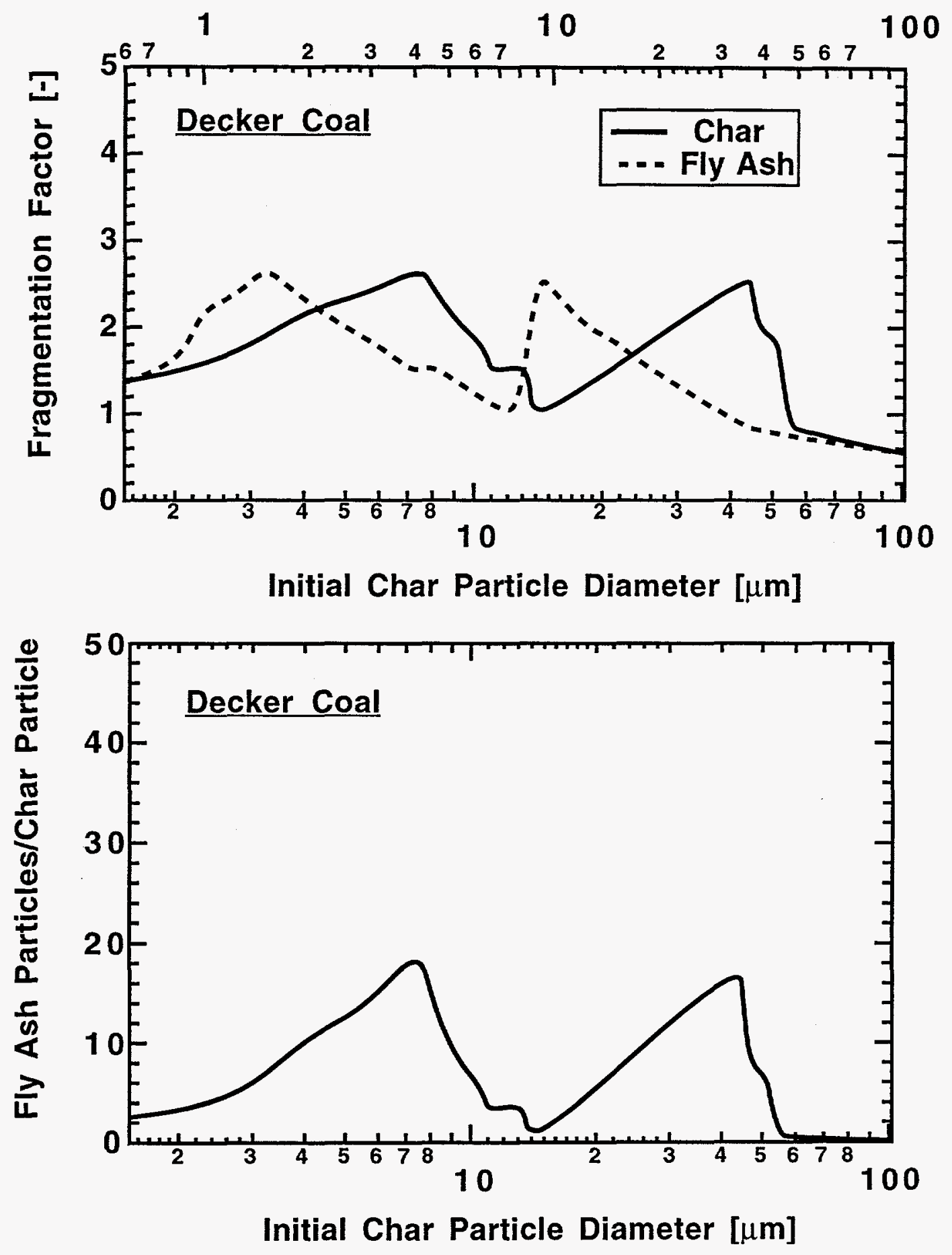

Figure 9. Variation of the fragmentation factor as a function of initial char and final fly ash particle sizes (a) and of the number of fly ash particles produced per char particle as a function of initial char particle size (b) for a Decker subbituminous A coal. 
Fly Ash Diameter $[\mu \mathrm{m}]$
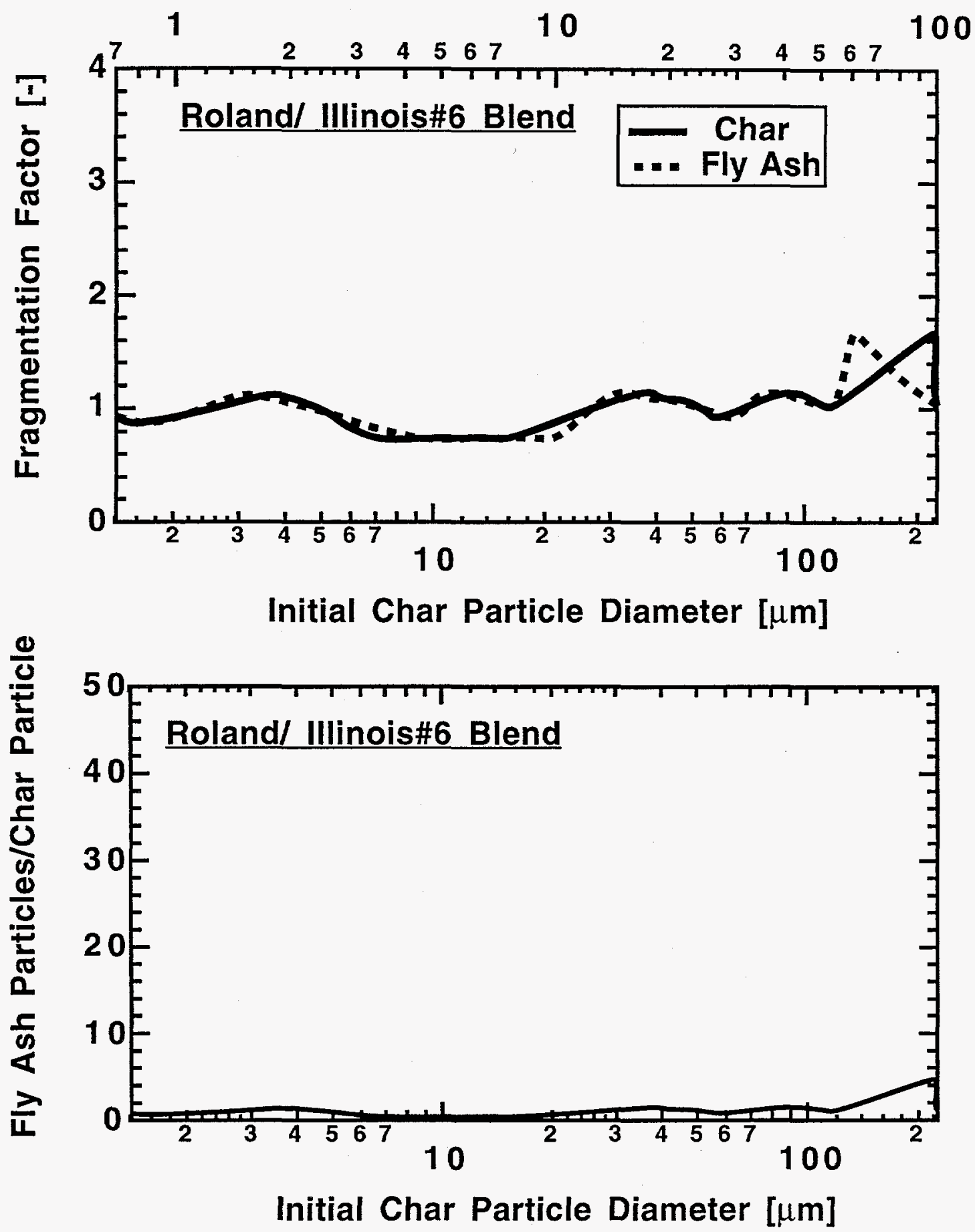

Figure 10. Variation of the fragmentation factor as a function of initial char and final fly ash particle sizes (a) and of the number of fly ash particles produced per char particle as a function of initial char particle size (b) for a blend of $70 \%$ Roland and $30 \%$ Illinois \# 6 (2) coals. 


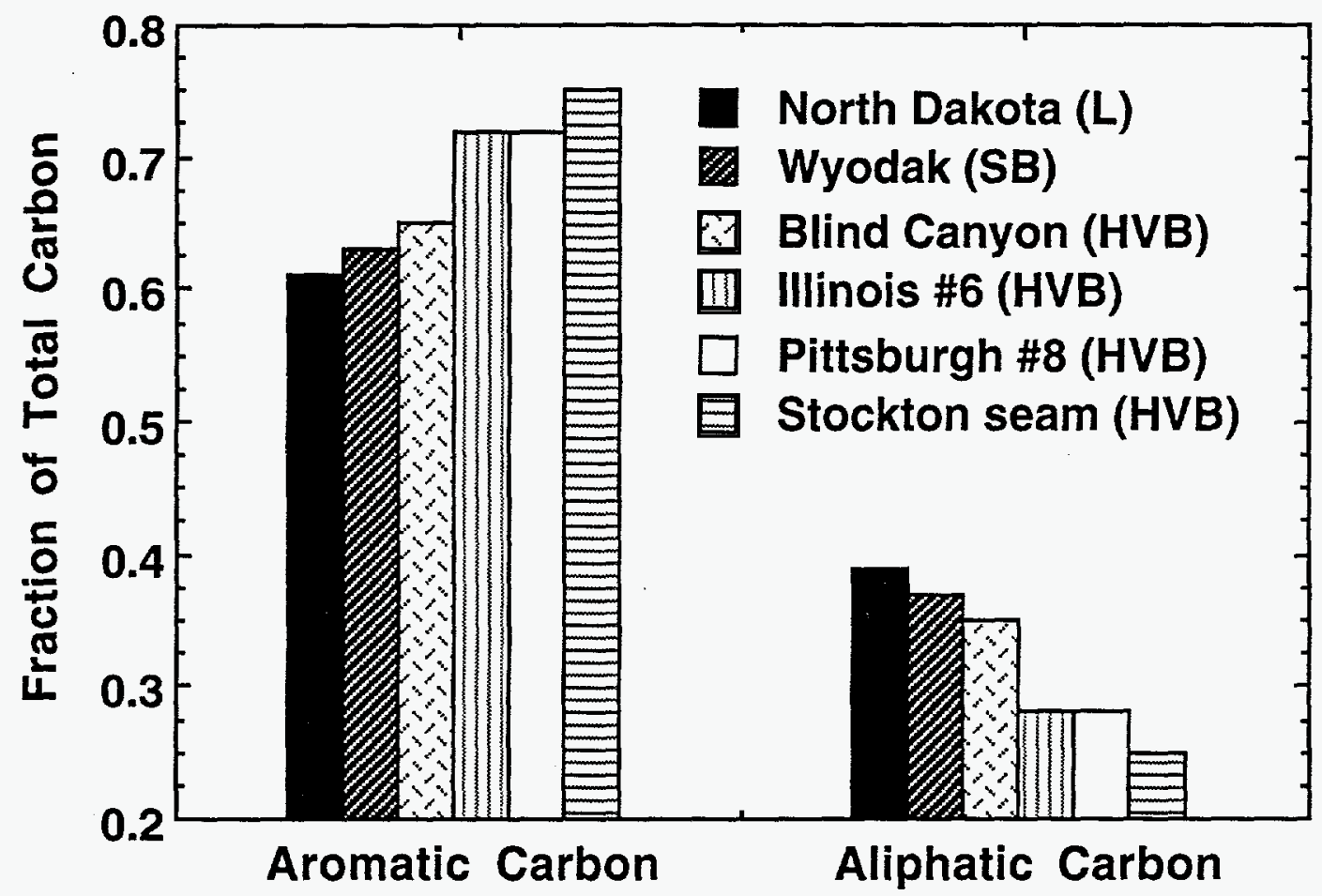

Figure 11. Comparison of the chemical composition of Argonne coal bank samples [Solum, et al., 1989] contrasting the Blind Canyon coal with coals similar to several used in these experiments.

The influence of ash loading on fragmentation behavior is minor. This can be seen by comparing results for the Kentucky \#9 coal with the Illinois \#6 (1) coal shown in Fig. 12 and Fig. 13. With reference to Table 2 and the appendix, these two coals are seen to be similar in most respects, with the exception that the Kentucky \#9 coal has roughly 50\% higher ash content than the Illinois \#6 (1) coal. Comparison of the similar data for the Kentucky \#9 and Illinois \#6 (1) coals with the data for the Beulah lignite (Figs. 12 and 13) clearly underscores the dominant importance of coal rank on fragmentation behavior.

\section{Conclusions}

The fragmentation data investigated thus far show consistent trends in that: (1) large char particles produce far more fly ash particles than small char particles; (2) the extent of fragmentation tends to increase with increasing coal rank through hv bituminous; (3) the extent of fragmentation tends to decrease with increasing ash loading; and (4) in all cases studied thus far, the total increase in the number of particles greater than $0.6 \mu \mathrm{m}$ in diameter by char fragmentation is less than a factor of two.

These general trends have been established for a significant number of coals over a broad range of rank, ash loading, and particle size. Our results indicate substantial agreement among experimental results previously thought to be in disagreement. 


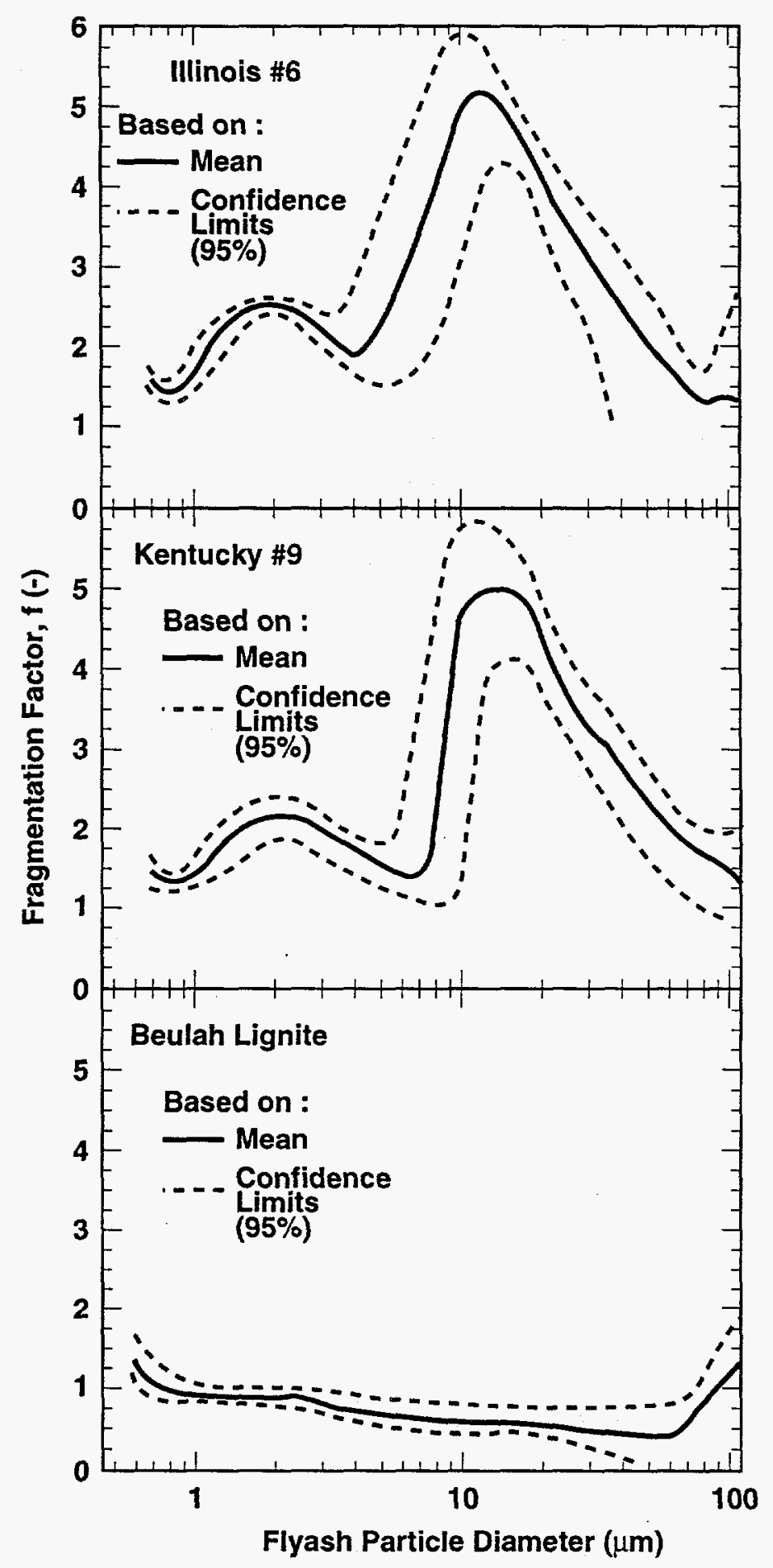

Figure 12. Variation of the fragmentation factor as a function of fly ash particle size for the Illinois \#6 (1) hv C bituminous coal, the Kentucky \#9 hv $\mathrm{C}$ bituminous coal, and the Beulah lignite. 


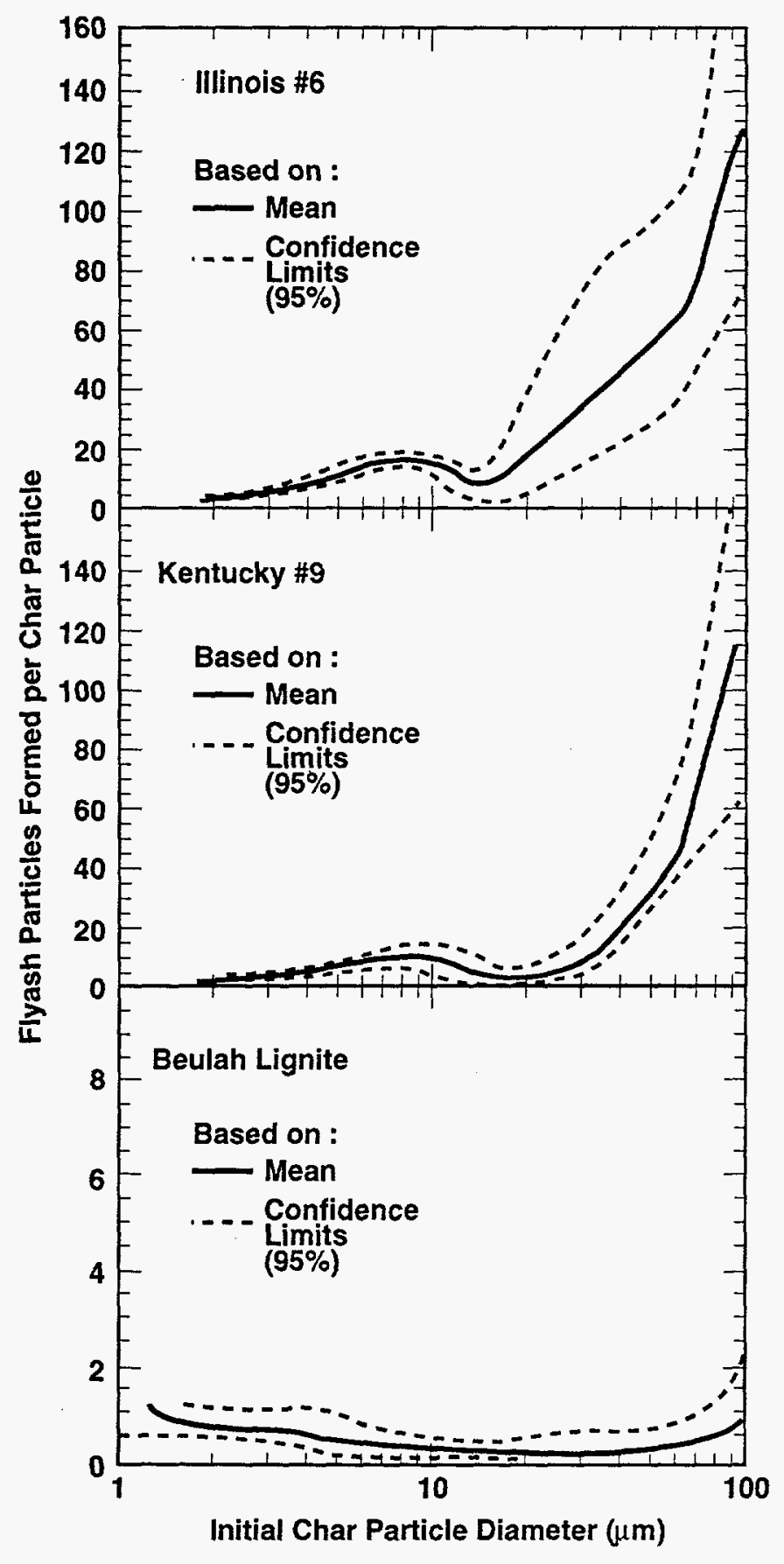

Figure 13. Variation of the number of fly ash particles produced per char particle as a function of initial char particle size for the Illinois \#6 (1) hv $\mathrm{C}$ bituminous coal, the Kentucky \#9 hv C bituminous coal, and the Beulah lignite. 
In particular, the dependence of char fragmentation on char particle size had not previously been recognized when comparing results from different systems. The implications of this particle-size dependence reconcile, in part, seemingly discrepant results previously reported in the literature. This is discussed in more detail elsewhere [Baxter, 1992]. Furthermore, the current study clearly indicates that, for typical coals in typical combustion environments, the extent of fragmentation experienced at all char particle sizes is relatively minor.

Finally, based upon our extensive data sets for a broad range of coals, a mechanistic description has been developed that predicts the trends observed in the data. However, significant additional work needs to be performed to establish quantitative relationships between fly ash chemistry and the size distributions of both the char particles and the mineral grains within the char particles.

\section{Practical Implications}

Combination of the coal and char data indicate that fragmentation under typical pulverizedcoal-fired conditions of particle size and oxygen concentrations: (1) is most significant for cenosphere-forming coals, (2) decreases slightly with increased ash loading, and (3) is relatively insignificant in all cases. These results have direct application to .

\section{Acknowledgments}

This work was performed under the management of Don Hardesty, whose guidance and continued interest in the work are gratefully acknowledged. The operation of the CCL and CDL laboratories during the early portions of this project was under the direction of Reginald Mitchell and Thomas Fletcher, respectively. The contributions of Nancy Yang and Don Nissen in obtaining SEM and EDS data for these samples are gratefully acknowledged. The contributions of Scott Ferko and Bill Kent in obtaining samples from the CCL and CDL are also gratefully acknowledged. A number of students, faculty, industrial visitors, contractors, Sandians, and other visitors helped in collecting data from the MFC. These include Gian Sclippa (TAD Technical Services), Alan Salmi (Sandia), Eric Harwood (UC Davis), Galen Richards (BYU), Joseph Wong (Cornell), Steve Giles (HS), Judy Lankford (HS), Howard Davis (Yale), Ed Muzio (Cornell), Robert Douglas (CONSOL), and Stan Harding (REI). The technical discussions and reviews of Robert Hurt, Judy Wornat, and Kevin Davis are also appreciated. Most of the fuel analyses on which this paper is based were performed by CONSOL Inc. as an in-kind contribution to this research.

\section{References}

Allen, R. M., and VanderSande, J. B. (1984). "Analysis of Sub-micron Mineral Matter in Coal via Scanning Transmission Electron Microscopy." Fuel, 63, 24-29.

Baxter, L. L. (1992). "Char Fragmentation and Fly Ash Formation During Pulverized Coal Combustion." Combustion and Flame, 90, 174-184.

Baxter, L. L., and Mitchell, R. E. (1992). "The Release of Iron During the Combustion of Illinois No. 6 Coal." Combustion and Flame, 88, 1-14. 
Baxter, L. L., Mitchell, R. E., and Fletcher, T. H. (1994 (to appear)). "Release of Inorganic Material During Coal Devolatilization." Combustion and Flame, to appear.

Canavos, G. C. (1984). Applied probability and statistical methods. Boston: Little, Brown and Company.

Dunn-Rankin, D., and Kerstein, A. R. (1987). "Numerical Simulation of Particle Size Distribution Evolution during Pulverized Coal Combusiton." Combustion and Flame, 69, 193-209.

Dunn-Rankin, D., and Kerstein, A. R. (1988). "Influence of Ash on Particle Size Distribution Evolution During Coal Combusiton." Combustion and Flame, 74, 207 218.

Flagan, R. C. (1978). "Submicron Particles from Coal Combustion,". In Seventeenth Symposium (International) on Combustion,, (pp. 97-104). University of Leeds, Leeds, England: The Combustion Institute.

Flagan, R. C., and Sarofim, A. F. (1984). "Comments to Article by W. T. Reid." Progress in Energy and Combustion Science, 10, 159-163.

Flagan, R. C., and Taylor, D. D. (1980). "Laboratory Studies of Submicron Particles from Coal Combustion". In Eighteenth Symposium (International) on Combustion, (pp. $1227-$ 1237). Waterloo, Canada: The Combustion Institute.

Holve, D., and Self, S. (1979a). "Optical particle sizing for in situ measurements: Part 1." Applied Optics, 18(10), 1632-1645.

Holve, D., and Self, S. A. (1979b). "Optical particle sizing for in situ measruements Part 2." Applied Optics, 18(10), 1646-1652.

Holve, D. J. (1986). "In Situ Measurements of Flyash Formation from Pulverized Coal." Combustion Science and Technology, 44, 269-288.

Holve, D. J., Tichenor, D., Wang, J. D. F., and Hardesty, D. R. (1981). "Design Criteria and recent developments of optical single particle counters for fossil fuel systems." Optical Engineering, 20(4), 529-539.

Kang, S.-G., Helble, J. J., Sarofim, A. F., and Beér, J. M. (1988). "Time-resolved Evolution of Fly Ash During Pulverized Coal Combustion". In Twenty-Second Symposium (International) on Combustion, (pp. 231-238). University of Washington, Seattle, WA: The Combustion Institute.

Kang, S.-G., Kerstein, A. R., Helble, J. J., and Sarofim, A. F. (1990). "Simulation of Residual Ash Formation During Pulverized Coal Combustion: Bimodal Ash Particle Size Distribution." Aeerosol Science and Technology, 13, 401-412.

Kerstein, A. R., and Edwards, B. F. (1987). "Percolation Model for Simulation of Char Oxidation and Fragmentation Time-Histories." Chemical Engineering Science, 42(7), 1629-1634.

Neville, M., Quann, R. J., Haynes, B. S., and Sarofim, A. F. (1980). "Vaporization and Condensation of Mineral Matter During Pulverized Coal Combustion". In The Eighteenth 
Symposium (International) on Combustion, (pp. 1267-1274). University of Waterloo, Waterloo, Canada: The Combustion Institute.

Neville, M., and Sarofim, A. F. (1985). "The Fate of Sodium During Pulverized Coal Combustion." Fuel, 64, 384-390.

Quann, R. J., Neville, M., Janghorbani, M., Mims, C. A., and Sarofim, A. F. (1982). "Mineral Matter and Trace-Element Vaporization in a Laboratory-Pulverized Coal Combustion System." Environmental Science and Technology, 16, 776-781.

Quann, R. J., Neville, M., and Sarofim, A. F. (1990). "A Laboratory Study of the Effect of Coal Selection on the Amount and Composition of Combustion Generated Submicron Particles." Combustion Science and Technology, 74, 245-265.

Quann, R. J., and Sarofim, A. F. (1982). "Vaporization of Refractory Oxides During Pulverized Coal Combustion". In Nineteenth Symposium (International) on Combustion, (pp. 1429-1440). The Combustion Institute.

Quann, R. J., and Sarofim, A. F. (1986). "A scanning electron microscopy study of the transformations of organically bound metals during lignite combustion." Fuel, 65, 40-46.

Raask, E. (1984). "Creation, capture and coalescence of coal species in coal flames." Journal of the Insitute of Energy, 57, 231.

Raask, E. (1985). Mineral Impurities in Coal Combustion. Washington: Hemisphere Publishing Corporation.

Sarofim, A. F., Howard, J. B., and Padia, A. S. (1977). "The Physical Transformation of the Mineral Matter in Pulverized Coal Under Simulated Combustion Conditions." Combustion Science and Technology, 16, 187-204.

Solum, M. S., Pugmire, R. J., and Grant, D. M. (1989). "13C Solid-State NMR of Argonne Premium Coals." Energy \& Fuels, 3, 187-193.

Wark, K., and Warner, C. F. (1981). Air Pollution (Second Edition ed.). New York: Harper \& Rwo.

Wibberley, L. J., and Wall, T. F. (1986). "An Investigation of Factors Affecting the Physical Characteristics of Flyash Formed in a Laboratory Scale Combustor." Combustion Science and Technology, 48, 177-190. 


\title{
APPENDIX A
}

\author{
Summaries of Analyses on Utility-Grind Samples of Coal
}

The following tables summarize the most commonly measured characteristics of the suite of utilitygrind coals tested in the multifuel combustor during this project. Included among the data are the results of moisture, proximate, ultimate, ash, ash chemistry, heating value, forms of sulfur, oxidizing and reducing fusion temperature, and particle size distribution analyses. The tables summarize average results for an often large number of samples. Not all analyses were performed on all samples. For example, proximate and ultimate analyses were not performed on the samples of coals used in chemical fractionation tests. This leads to occasional small discrepancies in, for example, the sum of the oxides and the total ash content, even when undetermined ash is included in the sum of oxides.

Additional characterizations of many of the coals have been performed. These include sizeresolved characterizations of the fraction of eastern and western coal in the blends, chemical fractionation results for about two thirds of the coals, and a variety of SEM-based and other individual-sample-based analyses. These additional analyses are available in published reports from this project but are not summarized here.

Blank entries indicate that no data are available. The most common examples include chlorine in ash (usually not measured), acid soluble alkali (available for small fraction of the coals), and one set of the Malvern size distribution data. The Malvern size data are reported in one of two alternative sets of ranges. Data from both ranges are rarely available. These Malvern data are for the pulverized, raw coal samples and they too have been averaged with several replicate measurements. 
Table A.1

Summary of utility-grind coals studied during this investigation.

\begin{tabular}{|c|c|c|c|c|c|}
\hline Coal & $\begin{array}{c}\text { Fixed } \\
\text { Carbon } \\
{[-]} \\
\end{array}$ & $\begin{array}{c}\text { Parr Values } \\
\text { Volatile } \\
\text { Matter } \\
{[-]} \\
\end{array}$ & $\begin{array}{l}\text { Heating } \\
\text { Value } \\
\text { Btu/lb }\end{array}$ & $\begin{array}{c}\text { Ash } \dagger \\
{[-]}\end{array}$ & Rank \\
\hline Pocahantas \#3 (1) & 81.2 & 18.8 & 15750 & 4.5 & lv Bituminous \\
\hline Upper Freeport ${ }^{\ddagger}$ & 71.45 & 28.55 & 15342 & 21.30 & mv Bituminous \\
\hline Mingo Logan & 64.18 & 35.82 & 15141 & 9.34 & hv A Bituminous \\
\hline Pittsburgh \#8 (3) & 59.01 & 40.99 & 15154 & 9.01 & hv A Bituminous \\
\hline Illinois \#6 (3) & 57.32 & 42.68 & 15023 & 5.62 & hv A Bituminous \\
\hline Pittsburgh \#8 (2) & 61.51 & 38.49 & 14843 & 6.62 & hv A Bituminous \\
\hline Massey Sprouce & 62.85 & 37.15 & 14786 & 8.33 & hv A Bituminous \\
\hline Eastern Kentucky & 59.76 & 40.24 & 14724 & 10.15 & hv A Bituminous \\
\hline Pittsburgh \#8 (1) & 56.44 & 43.56 & 14695 & 10.68 & hv A Bituminous \\
\hline Utah Blind Canyon & 51.92 & 48.08 & 14276 & 10.16 & hv A Bituminous \\
\hline Kentucky \#1 $1^{¥}$ & 57.38 & 42.62 & 13269 & 22.15 & hv B Bituminous \\
\hline Illinois \#6 (2) & 56.34 & 43.66 & 13083 & 12.21 & hv B Bituminous \\
\hline SOAP\$ & 57.6 & 42.4 & 12900 & 3.99 & hv C Bituminous \\
\hline Kentucky \#刑 & 57.15 & 42.85 & 12791 & 15.64 & hv C Bituminous \\
\hline Hanna Basin & 57.59 & 42.41 & 12053 & 9.99 & hv C Bituminous \\
\hline Illinois \#6 $(1)^{¥}$ & 55.68 & 44.32 & 11997 & 10.24 & hv C Bituminous \\
\hline Roland-Seam & 52.85 & 47.15 & 11494 & 6.16 & Subbituminous A \\
\hline Decker & 53.92 & 46.08 & 10726 & 5.12 & Subbituminous A \\
\hline Black Thunder & 42.27 & 57.73 & 10675 & 6.46 & Subbituminous A \\
\hline Belle Ayr & 49.02 & 50.98 & 10130 & 6.04 & Subbituminous B \\
\hline Wyodak & 51.79 & 48.21 & 10059 & 6.18 & Subbituminous B \\
\hline Antelope & 54.53 & 45.47 & 9918 & 5.51 & Subbituminous B \\
\hline Eagle Butte & 51.68 & 48.32 & 9286 & 6.37 & Subbituminous C \\
\hline Beulah Lignite & 51.28 & 48.72 & 8202 & 13.69 & Lignite A \\
\hline \multirow[t]{2}{*}{ Texas Lignite $¥$} & 39.98 & 60.02 & 7513 & 52.18 & Lignite A \\
\hline & & Blends & & & \\
\hline Eastern Blend & 67.77 & 32.23 & 15312 & 8.67 & hv A Bituminous \\
\hline Pitt. \#8/Decker & 61.3 & 38.7 & 13599 & 6.26 & hv B Bituminous \\
\hline NIPSCO Belnd (1) & 54.3 & 45.7 & 12786 & 7.80 & hv C Bituminous \\
\hline NIPSCO Blend (2) & 53.26 & 46.74 & 12742 & 7.71 & hv C Bituminous \\
\hline Roland/7linois \#6 & 54.3 & 45.7 & 12467 & 9.29 & hv C Bituminous \\
\hline Eagle Butte/Ken. \#9 & 51.3 & 48.7 & 10592 & 8.91 & Subbituminous A \\
\hline \multirow{2}{*}{\multicolumn{6}{|c|}{$\begin{array}{l}\text { * Fixed carbon and volatile matter are on dry, mineral-free (as opposed to ash-free) } \\
\text { basis. Heating value is on a moist. mineral-free basis. }\end{array}$}} \\
\hline & & & & & \\
\hline \multicolumn{6}{|c|}{$\dagger$ Ash is on a dry basis. } \\
\hline $\begin{array}{l}¥ \text { Coals obtained frc } \\
\text { investigations. }\end{array}$ & 10 & ro & 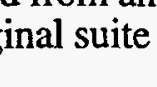 & & l \\
\hline
\end{tabular}


Table A.2 Properties of the Pocahantas \#3 coal.

Pocahantas \#3

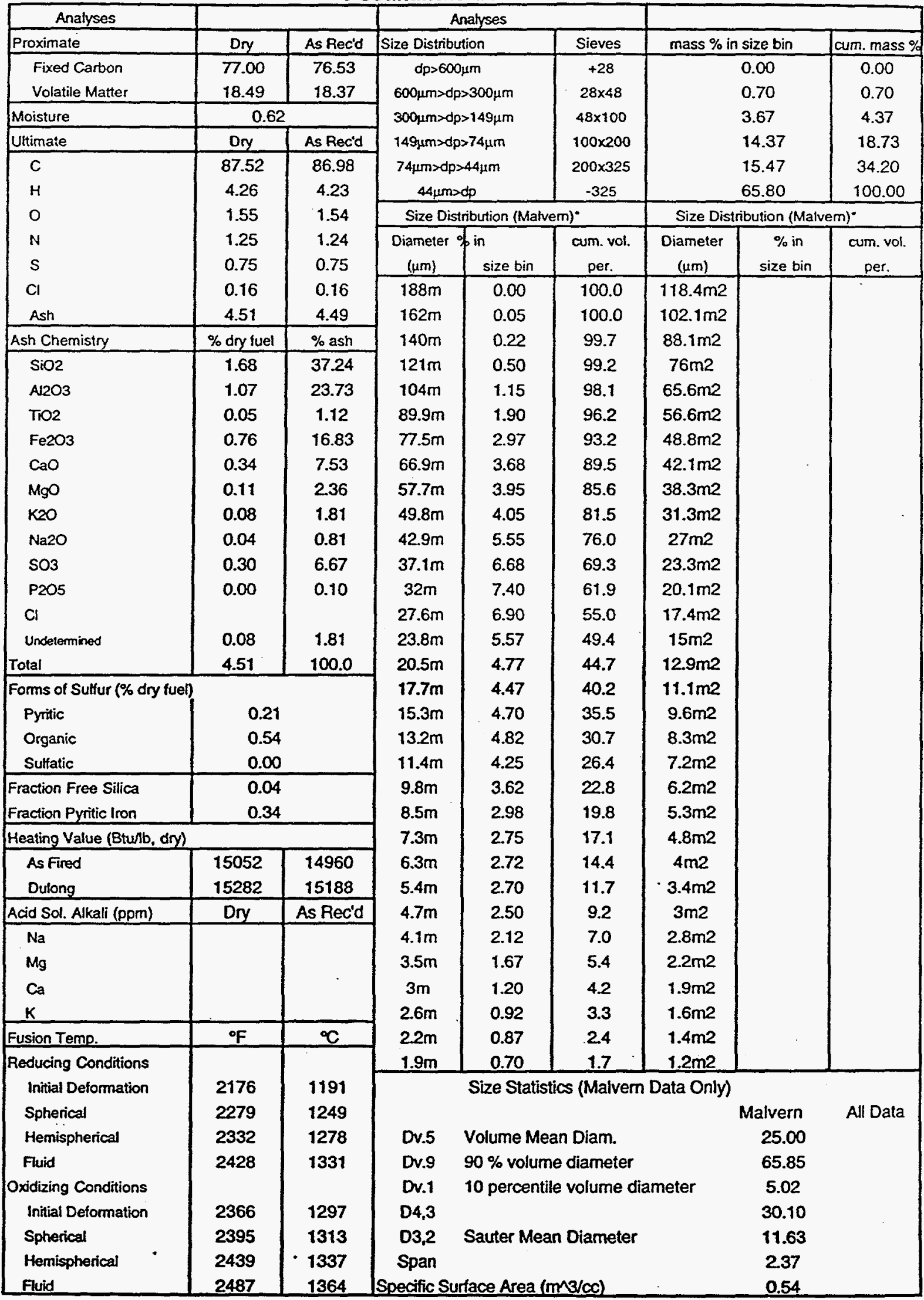

These Malvem data are for the 325 mesh size fractions. 
Table A.3 Summary of Properties of the Upper Freeport Coal.

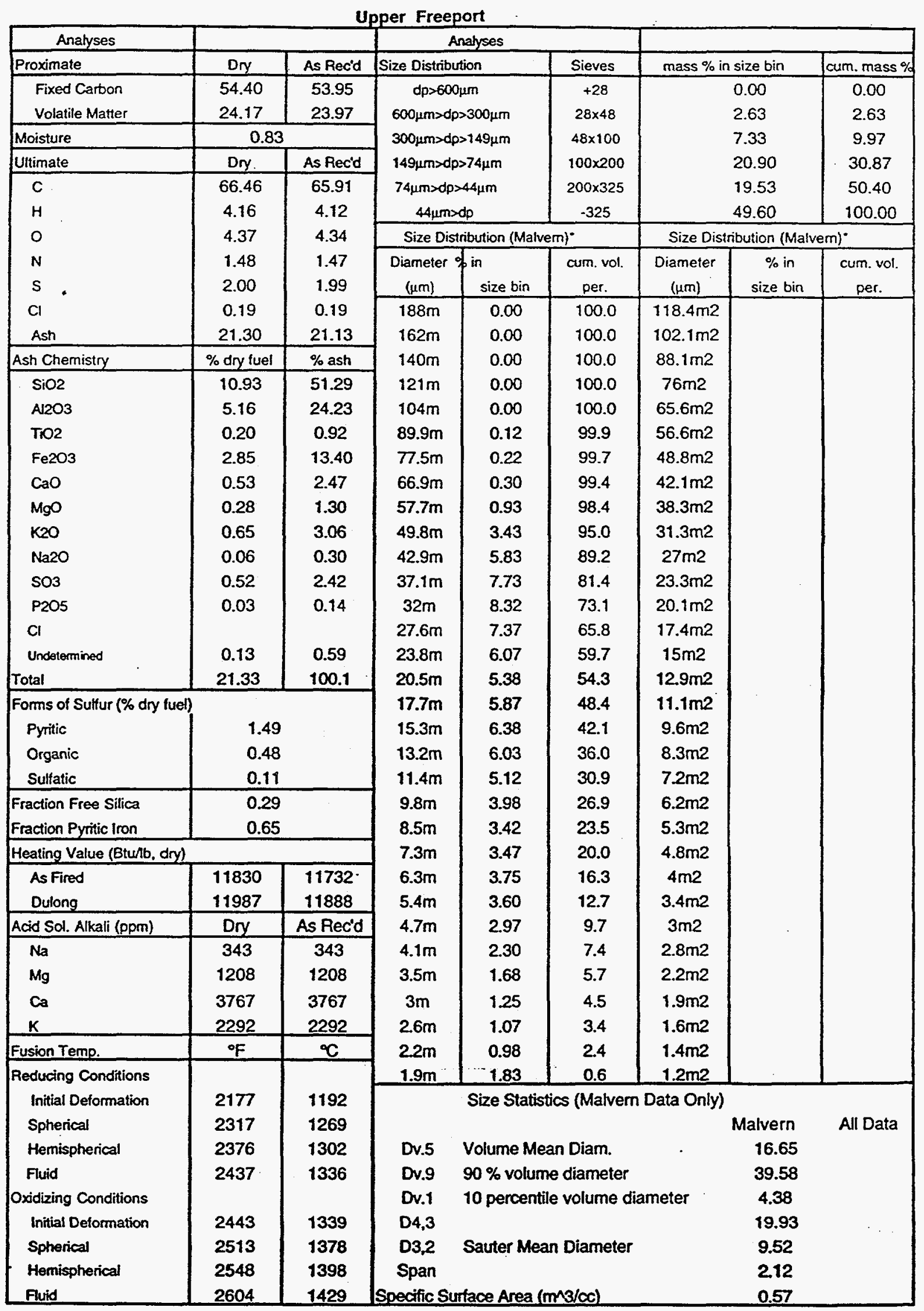

These Matvem data are for the -325 mesh size fractions. 
Table A.4 Summary of Properties of the Mingo Logan Coal.

Mingo Logan

\begin{tabular}{|c|c|c|c|c|c|c|c|c|}
\hline Analyses & & & \multicolumn{3}{|c|}{ Analyses } & & & \\
\hline Proximate & Dry & As Rec'd & Size Distribe & stion & Sieves & \multicolumn{2}{|c|}{ mass \% in size bin } & cum.mass \% \\
\hline Fixed Carbon & 57.53 & 56.70 & \multirow{3}{*}{\multicolumn{2}{|c|}{$\begin{array}{c}d p>600 \mu m \\
600 \mu m>d p>300 \mu m \\
300 \mu m>d p>149 \mu m\end{array}$}} & +28 & & 0.00 & 0.00 \\
\hline Volatile Matter & 33.13 & 32.65 & & & $28 \times 48$ & & 0.40 & 0.40 \\
\hline Moisture & \multicolumn{2}{|c|}{1.44} & & & $48 \times 100$ & & 4.75 & 5.15 \\
\hline Uttimate & Dry & As Rec'd & \multicolumn{2}{|c|}{$149 \mu m>0 p>74 \mu m$} & $100 \times 200$ & & 17.65 & 22.80 \\
\hline C & 78.14 & 77.01 & \multicolumn{2}{|c|}{$74 \mu \mathrm{m}>\mathrm{dp}>\triangle 4 \mu \mathrm{m}$} & $200 \times 325$ & & 19.10 & 41.90 \\
\hline$H$ & 4.94 & 4.87 & \multicolumn{2}{|c|}{$44 \mu m \geq d p$} & -325 & & 58.10 & 100.00 \\
\hline 0 & 5.28 & 5.20 & \multicolumn{3}{|c|}{ Size Distribution (Malvern) } & \multicolumn{3}{|c|}{ Size Distribution (Malvem) } \\
\hline$N$ & 1.29 & 1.27 & \multirow{5}{*}{$\begin{array}{c}\text { Diameter } \\
(\mu \mathrm{m}) \\
188 \mathrm{~m} \\
162 \mathrm{~m} \\
140 \mathrm{~m}\end{array}$} & \multirow{2}{*}{$\int_{\text {size bin }}$} & cum. vol. & \multirow{2}{*}{$\begin{array}{c}\text { Diameter } \\
(\mu \mathrm{m}) \\
\end{array}$} & \multirow{2}{*}{$\begin{array}{c}\begin{array}{c}\% \text { in } \\
\text { size bin }\end{array} \\
\end{array}$} & \multirow{2}{*}{$\begin{array}{c}\text { cum. vol. } \\
\text { per. }\end{array}$} \\
\hline $\mathbf{s}$ & 0.87 & 0.85 & & & per. & & & \\
\hline $\mathrm{Cl}$ & 0.15 & 0.15 & & 0.00 & 100.0 & $118.4 \mathrm{~m} 2$ & & \\
\hline Ash & 9.34 & 9.21 & & 0.00 & 100.0 & $102.1 \mathrm{~m} 2$ & & \\
\hline Ash Chemistry & $\%$ dry fuel & $\%$ ash & & 0.00 & 100.0 & $88.1 \mathrm{~m} 2$ & & \\
\hline $\mathrm{SiO} 2$ & 5.14 & 55.07 & $121 \mathrm{~m}$ & 0.00 & 100.0 & $76 \mathrm{~m} 2$ & & \\
\hline $\mathrm{A} 2 \mathrm{O} 3$ & 2.80 & 29.96 & $104 m$ & 0.00 & 100.0 & $65.6 \mathrm{~m} 2$ & & \\
\hline TrO2 & 0.13 & 1.41 & $89.9 m$ & 0.00 & 100.0 & $56.6 \mathrm{~m} 2$ & & \\
\hline $\mathrm{Fe} 2 \mathrm{O} 3$ & 0.60 & 6.38 & $77.5 \mathrm{~m}$ & 0.08 & 99.9 & $48.8 \mathrm{~m} 2$ & & \\
\hline $\mathrm{CaO}$ & 0.10 & 1.07 & $66.9 m$ & 1.13 & 98.8 & $42.1 \mathrm{~m} 2$ & & \\
\hline $\mathrm{MgO}$ & 0.10 & 1.02 & $57.7 m$ & 3.25 & 95.6 & $38.3 \mathrm{~m} 2$ & & \\
\hline $\mathrm{K} 2 \mathrm{O}$ & 0.27 & 2.91 & $49.8 m$ & 5.65 & 89.9 & $31.3 \mathrm{~m} 2$ & & \\
\hline $\mathrm{Na} 2 \mathrm{O}$ & 0.05 & 0.49 & $42.9 m$ & 7.50 & 82.4 & $27 \mathrm{~m} 2$ & & \\
\hline $\mathrm{SO} 3$ & 0.11 & 1.22 & $37.1 \mathrm{~m}$ & 8.95 & 73.5 & $23.3 \mathrm{~m} 2$ & & \\
\hline P2O5 & 0.01 & 0.09 & $32 m$ & 8.60 & 64.9 & $20.1 \mathrm{~m} 2$ & & \\
\hline $\mathrm{Cl}$ & & & $27.6 m$ & 6.95 & 57.9 & $17.4 \mathrm{~m} 2$ & & \\
\hline Undetermined & 0.04 & 0.39 & $23.8 \mathrm{~m}$ & 5.83 & 52.1 & $15 \mathrm{~m} 2$ & & \\
\hline Total & 9.34 & 100.0 & $20.5 m$ & 5.38 & 46.7 & $12.9 \mathrm{~m} 2$ & & \\
\hline \multicolumn{3}{|c|}{ Forms of Sulfur (\% dry fuel) } & $17.7 \mathrm{~m}$ & 5.78 & 40.9 & $11.1 \mathrm{~m} 2$ & & \\
\hline Pyritic & \multicolumn{2}{|c|}{0.23} & $15.3 \mathrm{~m}$ & 5.93 & 35.0 & $9.6 \mathrm{~m} 2$ & & \\
\hline Organic & \multicolumn{2}{|c|}{0.64} & $13.2 \mathrm{~m}$ & 5.05 & 29.9 & $8.3 \mathrm{~m} 2$ & & \\
\hline Sulfatic & \multicolumn{2}{|c|}{0.00} & $11.4 \mathrm{~m}$ & 4.10 & 25.8 & $7.2 \mathrm{~m} 2$ & & \\
\hline Fraction Free Silica & \multicolumn{2}{|c|}{$\begin{array}{l}0.18 \\
0.48\end{array}$} & $9.8 \mathrm{~m}$ & 3.23 & 22.6 & $6.2 \mathrm{~m} 2$ & & \\
\hline Fraction Pyritic Iron & 0.48 & & $8.5 \mathrm{~m}$ & 3.00 & 19.6 & $5.3 \mathrm{~m} 2$ & & \\
\hline Heating Value (Btunb, & & & $7.3 m$ & 3.10 & 16.5 & $4.8 \mathrm{~m} 2$ & & \\
\hline As Fined & 13805 & 13607 & $6.3 m$ & 3.25 & 13.3 & $4 m 2$ & & \\
\hline Dulong & 14054 & 13852 & $5.4 \mathrm{~m}$ & 2.90 & 10.4 & $3.4 \mathrm{~m} 2$ & & \\
\hline Add Sol. Alkali (pom) & Dry & As Rec'd & $4.7 m$ & 2.33 & 8.0 & $3 m 2$ & & \\
\hline $\mathrm{Na}$ & & . & $4.1 \mathrm{~m}$ & 1.80 & 6.2 & $2.8 \mathrm{~m} 2$ & & \\
\hline $\mathrm{Mg}$ & & & $3.5 m$ & 1.30 & 4.9 & $2.2 \mathrm{~m} 2$ & & \\
\hline $\mathrm{Ca}$ & & & $3 m$ & 1.05 & 3.9 & $1.9 \mathrm{~m} 2$ & $\cdot$ & \\
\hline$K$ & & & $2.6 \mathrm{~m}$ & 0.98 & 2.9 & $1.6 \mathrm{~m} 2$ & & \\
\hline Fusion Temp. & ${ }^{\circ} \mathrm{F}$ & ${ }^{\circ} \mathrm{C}$ & $2.2 m$ & 0.85 & 21 & $1.4 \mathrm{~m} 2$ & & \\
\hline Reducing Conditions & & & $1.9 \mathrm{~m}$ & 2.08 & 0.0 & $1.2 \mathrm{~m} 2$ & & \\
\hline Initial Deformation & 1428 & 776 & & Size Statis & as (Malvern & Data Only) & & \\
\hline Spherical & 1442 & 783 & & & & & Malvern & All Data \\
\hline Hemispherical & 1451 & 788 & Dv.5 & Volume $M$ & n Diam. & & 19.38 & \\
\hline Fluid & 1473 & 800 & Dv.9 & $90 \%$ volun & diameter & & 43.00 & \\
\hline Oxidizing Conditions & & & Dv.1 & 10 percent & volume di & meter & 4.60 & \\
\hline Initial Deformation & 1445 & 785 & D4,3 & & & & 21.03 & \\
\hline Spherical & 1463 & 795 & D3,2 & Sauter Me & Diameter & & 10.00 & \\
\hline Hemispherical & 1471 & 799 & Span & & & & 2.00 & \\
\hline Fluid & 1486 & 808 & Specific Su & rface Area & $13 /(x)$ & & 0.62 & \\
\hline
\end{tabular}

These Matven data are for the -325 mesh size fractions. 
Table A.5 Summary of Properties of the Pittsburgh \#8 (3) Coal.

\begin{tabular}{|c|c|c|c|c|c|c|c|c|}
\hline Analyses & \multicolumn{5}{|c|}{ Analyses } & \multirow{2}{*}{\multicolumn{2}{|c|}{ mass $\%$ in size bin }} & \\
\hline Proximate & Dry & As Rec'd & Size Distribu & ution & Sieves & & & aum. mass $\%$ \\
\hline Fixed Carbon & 52.64 & 52.06 & \multirow{3}{*}{\multicolumn{2}{|c|}{$\begin{array}{c}d p>600 \mu m \\
600 \mu m>d p>300 \mu m \\
300 \mu m>d p>149 \mu m\end{array}$}} & +28 & & 0.00 & 0.00 \\
\hline Volatile Matter & 38.22 & 37.80 & & & $28 \times 48$ & & 2.27 & 2.27 \\
\hline Moisture & \multicolumn{2}{|c|}{1.10} & & & $48 \times 100$ & & 4.10 & 6.37 \\
\hline Ultimate & Dry & As Rec'd & \multicolumn{2}{|c|}{$149 \mu m>d p>74 \mu m$} & $100 \times 200$ & & 26.17 & 32.53 \\
\hline $\mathrm{C}$ & 76.50 & 75.66 & \multicolumn{2}{|c|}{$74 \mu m>d p>44 \mu m$} & $200 \times 325$ & & 22.33 & 54.87 \\
\hline$H$ & 5.07 & 5.02 & \multicolumn{2}{|c|}{$44 \mu m>d p$} & -325 & & 45.13 & 100.00 \\
\hline 0 & 4.29 & 4.24 & \multicolumn{3}{|c|}{ Size Distribution (Malvem) } & \multicolumn{3}{|c|}{ Size Distribution (Malvem) } \\
\hline$N$ & 1.39 & 1.38 & \multirow{5}{*}{$\begin{array}{c}\text { Diameter } \\
(\mu \mathrm{m}) \\
188 \mathrm{~m} \\
162 \mathrm{~m} \\
140 \mathrm{~m}\end{array}$} & on in & cum. vol. & Diameter & $\%$ in & cum. vol. \\
\hline$S$ & 3.52 & 3.48 & & size bin & per. & $(\mu m)$ & size bin & per. \\
\hline $\mathrm{Cl}$ & 0.09 & 0.09 & & 0.31 & 99.7 & $118.4 \mathrm{~m} 2$ & & \\
\hline Ash & 9.01 & 8.91 & & 0.83 & 98.9 & $102.1 \mathrm{~m} 2$ & & \\
\hline Ash Chemistry & $\%$ dry fuel & $\%$ ash & & 1.24 & 97.6 & $88.1 \mathrm{~m} 2$ & & \\
\hline $\mathrm{SiO} 2$ & 3.53 & 39.16 & $121 \mathrm{~m}$ & 1.59 & 96.0 & $76 \mathrm{~m} 2$ & & \\
\hline $\mathrm{Al} 2 \mathrm{O} 3$ & 1.74 & 19.31 & $104 m$ & 1.70 & 94.3 & $65.6 \mathrm{~m} 2$ & & \\
\hline TO2 & 0.08 & 0.84 & $89.9 m$ & 1.91 & 92.4 & $56.6 \mathrm{~m} 2$ & & \\
\hline $\mathrm{Fe} 2 \mathrm{O} 3$ & 2.48 & 27.53 & $77.5 \mathrm{~m}$ & 2.24 & 90.2 & $48.8 \mathrm{~m} 2$ & & \\
\hline $\mathrm{CaO}$ & 0.41 & 4.56 & $66.9 \mathrm{~m}$ & 2.69 & 87.5 & $42.1 \mathrm{~m} 2$ & & \\
\hline $\mathrm{MgO}$ & 0.08 & 0.84 & $57.7 m$ & 3.26 & 84.2 & $38.3 m 2$ & & \\
\hline$K 20$ & 0.11 & 1.18 & $49.8 m$ & 4.84 & 79.4 & $31.3 \mathrm{~m} 2$ & & \\
\hline $\mathrm{Na} 2 \mathrm{O}$ & 0.08 & 0.87 & $42.9 m$ & 6.24 & 73.2 & $27 \mathrm{~m} 2$ & & \\
\hline SO3 & 0.37 & 4.08 & $37.1 \mathrm{~m}$ & 7.04 & 66.1 & $23.3 \mathrm{~m} 2$ & & \\
\hline $\mathrm{P} 2 \mathrm{O5}$ & 0.03 & 0.34 & $32 m$ & 6.28 & 59.9 & $20.1 \mathrm{~m} 2$ & & \\
\hline $\mathrm{Cl}$ & & & $27.6 \mathrm{~m}$ & 4.81 & 55.0 & $17.4 \mathrm{~m} 2$ & & \\
\hline Undeternined & 0.11 & 1.25 & $23.8 \mathrm{~m}$ & 4.35 & 50.7 & $15 \mathrm{~m} 2$ & & \\
\hline Tolal & 9.01 & 100.0 & $20.5 m$ & 4.58 & 46.1 & $12.9 \mathrm{~m} 2$ & & \\
\hline \multicolumn{3}{|c|}{ Forms of Sulfur (\% dry fuel) } & $17.7 \mathrm{~m}$ & 4.74 & 41.4 & $11.1 \mathrm{~m} 2$ & & \\
\hline Pyritic & \multicolumn{2}{|l|}{2.07} & $15.3 \mathrm{~m}$ & 4.61 & 36.8 & $9.6 \mathrm{~m} 2$ & & \\
\hline Organic & \multicolumn{2}{|l|}{1.42} & $13.2 \mathrm{~m}$ & 4.15 & 32.6 & $8.3 \mathrm{~m} 2$ & & \\
\hline Sulfatic & \multicolumn{2}{|l|}{0.03} & $11.4 \mathrm{~m}$ & 3.74 & 28.9 & $7.2 \mathrm{~m} 2$ & & \\
\hline Fraction Free Sillica & \multirow{2}{*}{\multicolumn{2}{|c|}{$\begin{array}{l}0.26 \\
0.61\end{array}$}} & $9.8 \mathrm{~m}$ & 3.39 & 25.5 & $6.2 \mathrm{~m} 2$ & & \\
\hline Fraction Pyritic Iron & & & $8.5 m$ & 3.16 & 22.3 & $5.3 \mathrm{~m} 2$ & & \\
\hline \multicolumn{3}{|c|}{ Heating Value (Btunb, dry) } & $7.3 \mathrm{~m}$ & 3.01 & 19.3 & $4.8 \mathrm{~m} 2$ & & \\
\hline As Fired & 13728 & 13577 & $6.3 m$ & 2.99 & 16.3 & $4 m 2$ & & \\
\hline Dulong & 13523 & 13374 & $5.4 m$ & 2.96 & 13.4 & $3.4 \mathrm{~m} 2$ & & \\
\hline Acid Sol. Alkali (ppm) & Dry & As Rec'd & $4.7 \mathrm{~m}$ & 2.73 & 10.6 & $3 m 2$ & & \\
\hline $\mathrm{Na}$ & & & $4.1 \mathrm{~m}$ & 2.14 & 8.5 & $2.8 \mathrm{~m} 2$ & & \\
\hline $\mathrm{Mg}$ & & & $3.5 \mathrm{~m}$ & 1.68 & 6.8 & $2.2 \mathrm{~m} 2$ & & \\
\hline $\mathrm{Ca}$ & - & & $3 m$ & 1.30 & 5.5 . & $1.9 \mathrm{~m} 2$ & & \\
\hline $\mathbf{K}$ & & & $2.6 \mathrm{~m}$ & 1.16 & 4.4 & $1.6 \mathrm{~m} 2$ & & \\
\hline Fusion Temp. & ${ }^{\circ} \mathrm{F}$ & ${ }^{\circ} \mathrm{C}$ & $2.2 \mathrm{~m}$ & 1.11 & 3.3 & $1.4 \mathrm{~m} 2$ & & \\
\hline Reducing Conditions & \multicolumn{8}{|c|}{$1.2 \mathrm{~m} 2$} \\
\hline Initial Deformation & 1984 & 1085 & \multicolumn{6}{|c|}{ Size Statistics (Malvem Data Only) } \\
\hline Spherical & 2020 & 1104 & & & & & Malvern & All Data \\
\hline Hemispherical & 2080 & 1138 & Dv.5 & Volume Me & Diam. & & 25.04 & \\
\hline Fluid & 2245 & 1229 & Dv.9 & $90 \%$ volun & diameter & & 63.86 & \\
\hline Oxidizing Conditions & & & Dv.1 & 10 percent & volume di & meter & 4.51 & . \\
\hline Initial Deformation & 2387 & 1308 & D 4,3 & & & & 30.11 & \\
\hline Spherical & 2448 & 1342 & $\mathrm{D} 3,2$ & Sauter Me: & Diameter & & 10.70 & \\
\hline Hemispherical & 2496 & 1369 & Span & & & & 2.56 & \\
\hline Fluid & 2542 & 1394 & Specific Su & iface Area ( & $3(\infty)$ & & 0.66 & \\
\hline
\end{tabular}

These Malvern data are for the -325 mesh size fractions. 
Table A.6 Summary of Properties of the Illinois \#6 (3) Coal.

Illinois \#6(3)

\begin{tabular}{|c|c|c|c|c|c|c|c|c|}
\hline \multirow{2}{*}{\begin{tabular}{|l} 
Analyses \\
Proximate \\
\end{tabular}} & & & \multicolumn{3}{|c|}{ Anatyses } & \multirow{2}{*}{\multicolumn{2}{|c|}{ mass $\%$ in size bin }} & \multirow[b]{2}{*}{ cum. mass $\%$} \\
\hline & Dry & As Rec'd & \multicolumn{2}{|c|}{ Size Distribution } & Sieves & & & \\
\hline Fixed Carbon & 58.15 & 56.51 & \multirow{3}{*}{\multicolumn{2}{|c|}{$\begin{array}{c}d p>600 \mu m \\
600 \mu m>d p>300 \mu m \\
300 \mu m>d p>149 \mu m\end{array}$}} & +28 & & 0.00 & 0.00 \\
\hline Volatile Matter & 36.24 & 35.22 & & & $28 \times 48$ & & 0.15 & 0.15 \\
\hline Moisture & \multicolumn{2}{|c|}{2.81} & & & $48 \times 100$ & & 2.50 & 2.65 \\
\hline Ultimate & Dry & As Rec'd & \multicolumn{2}{|c|}{$149 \mu m>d p>74 \mu m$} & $100 \times 200$ & & 14.10 & 16.75 \\
\hline C & 78.18 & 75.98 & \multicolumn{2}{|c|}{$74 \mu m>d p>44 \mu m$} & $200 \times 325$ & & 19.75 & 36.50 \\
\hline$H$ & 5.02 & 4.87 & $44 \mu m>$ & & -325 & & 63.50 & 100.00 \\
\hline $\mathrm{O}$ & 8.25 & 8.02 & \multicolumn{3}{|c|}{ Size Distribution (Maivern) } & \multicolumn{3}{|c|}{ Size Distribution (Malvem) } \\
\hline$N$ & 1.62 & 1.57 & Diameter & $\%$ in & cum. vol. & Diameter of & in & cum. vol. \\
\hline s & 0.95 & 0.92 & $(\mu m)$ & size bin & per. & $(\mu \mathrm{m})$ & size bin & per. \\
\hline $\mathrm{Cl}$ & 0.38 & 0.37 & $188 \mathrm{~m}$ & 0.00 & 100.0 & $118.4 \mathrm{~m} 2$ & & \\
\hline Ash & 5.62 & 5.46 & $162 m$ & 0.08 & 99.9 & $102.1 \mathrm{~m} 2$ & & \\
\hline Ash Chemistry & $\%$ dry fuet & $\%$ ash & $140 \mathrm{~m}$ & 0.10 & 99.8 & $88.1 \mathrm{~m} 2$ & & \\
\hline $\mathrm{SiO} 2$ & 2.98 & 53.00 & $121 \mathrm{~m}$ & 0.10 & 99.7 & $76 \mathrm{~m} 2$ & & \\
\hline $\mathrm{Al} 2 \mathrm{O} 3$ & 1.36 & 24.18 & $104 m$ & 0.10 & 99.6 & $65.6 \mathrm{~m} 2$ & & \\
\hline TrO2 & 0.07 & 1.28 & $89.9 m$ & 0.23 & 99.4 & $56.6 \mathrm{~m} 2$ & & \\
\hline $\mathrm{Fe} 2 \mathrm{O} 3$ & 0.64 & 11.44 & $77.5 m$ & 1.20 & 98.2 & $48.8 \mathrm{~m}^{2}$ & & \\
\hline $\mathrm{CaO}$ & 0.12 & 2.19 & $66.9 m$ & 2.95 & 95.3 & $42.1 \mathrm{~m} 2$ & & \\
\hline $\mathrm{MgO}$ & 0.06 & 1.03 & $57.7 m$ & 5.40 & 89.9 & $38.3 \mathrm{~m} 2$ & & \\
\hline $\mathrm{K} 20$ & 0.13 & 2.39 & $49.8 m$ & 7.88 & 82.0 & $31.3 \mathrm{~m} 2$ & & \\
\hline $\mathrm{Na} 2 \mathrm{O}$ & 0.14 & 2.41 & $42.9 m$ & 8.90 & 73.1 & $27 \mathrm{~m} 2$ & & \\
\hline $\mathrm{SO} 3$ & 0.11 & 2.00 & $37.1 \mathrm{~m}$ & 9.13 & 64.0 & $23.3 \mathrm{~m} 2$ & & \\
\hline $\mathrm{P} 2 \mathrm{O} 5$ & 0.01 & 0.24 & $32 m$ & 8.13 & 55.8 & $20.1 \mathrm{~m} 2$ & & \\
\hline $\mathrm{Cl}$ & & & $27.6 m$ & 6.55 & 49.3 & $17.4 \mathrm{~m} 2$ & & \\
\hline Undetemined & -0.01 & -0.17 & $23.8 \mathrm{~m}$ & 5.85 & 43.4 & $15 \mathrm{~m} 2$ & & \\
\hline Total & 5.62 & 100.0 & $20.5 m$ & 5.70 & 37.7 & $12.9 \mathrm{~m} 2$ & & \\
\hline \multicolumn{3}{|c|}{ Forms of Sulfur (\% dry fuel) } & $17.7 m$ & 5.73 & 32.0 & $11.1 \mathrm{~m} 2$ & & \\
\hline Pyritic & \multicolumn{2}{|c|}{0.36} & $15.3 \mathrm{~m}$ & 5.38 & 26.6 & $9.6 \mathrm{~m} 2$ & & \\
\hline Organic & \multicolumn{2}{|c|}{0.57} & $13.2 \mathrm{~m}$ & 4.33 & 22.3 & $8.3 \mathrm{~m} 2$ & & \\
\hline Sulfatic & \multicolumn{2}{|c|}{0.02} & $11.4 \mathrm{~m}$ & 3.58 & 18.7 & $7.2 \mathrm{~m} 2$ & & \\
\hline Fraction Free Silica & \multicolumn{2}{|c|}{0.32} & $9.8 \mathrm{~m}$ & 2.98 & 15.8 & $6.2 \mathrm{~m} 2$ & & \\
\hline Fraction Pyntic Iron & \multicolumn{2}{|c|}{0.70} & $8.5 m$ & 2.70 & 13.1 & $5.3 \mathrm{~m} 2$ & & \\
\hline \multicolumn{3}{|c|}{ Heating Value (Btu/lb, dry) } & $7.3 m$ & 2.53 & 10.5 & $4.8 \mathrm{~m} 2$ & & \\
\hline As Fired & 14516 & 14108 & $6.3 m$ & 2.30 & 8.2 & $4 m 2$ & & \\
\hline Dulong & 13879 & 13489 & $5.4 m$ & 2.03 & 6.2 & $3.4 \mathrm{~m} 2$ & & \\
\hline Acid Sol. Alkali (ppm) & Dry & As Rec'd & $4.7 m$ & 1.78 & 4.4 & $3 m 2$ & . & \\
\hline $\mathrm{Na}$ & & & $4.1 \mathrm{~m}$ & 1.23 & 3.2 & $2.8 \mathrm{~m} 2$ & & \\
\hline $\mathrm{Mg}$ & & & $3.5 m$ & 1.08 & 2.1 & $2.2 \mathrm{~m} 2$ & & \\
\hline $\mathrm{Ca}$ & & & $3 m$ & 0.70 & 1.4 & $1.9 \mathrm{~m} 2$ & & \\
\hline $\mathbf{K}$ & & & $2.6 \mathrm{~m}$ & 0.48 & 1.0 & $1.6 \mathrm{~m} 2$ & & \\
\hline Fusion Temp. & of & ${ }^{\circ} \mathrm{C}$ & $2.2 m$ & 0.35 & 0.6 & $1.4 \mathrm{~m} 2$ & & \\
\hline Reducing Conditions & & & $1.9 \mathrm{~m}$ & 0.73 & $-0.1^{\circ}$ & $1.2 \mathrm{~m} 2$ & & \\
\hline Initial Deformation & 1081 & 583 & \multicolumn{6}{|c|}{ Size Statistics (Malvem Data Only) } \\
\hline Spherical & 1183 & 639 & & & & & Malvern & All Data \\
\hline Hemispherical & 1228 & 664 & Dv.5 & Volume M & Diam. & & 24.13 & \\
\hline Fluid & 1271 & 688 & Dv.9 & $90 \%$ volur & diameter & & 49.83 & \\
\hline Oxidizing Conditions & & & Dv.1 & 10 percent & volume di & meter & 6.08 & \\
\hline Initial Deformation & 1232 & 666 & D4,3 & & & & 27.03 & \\
\hline Spherical & 1258 & 681 & D3,2 & Sauter Me & Dlameter & & 13.40 & \\
\hline Hemispherical & 1280 & 693 & Span & & & & 1.80 & \\
\hline Fuid & 1308 & 709 & Specific Su & face Area & $3(\infty)$ & & 0.45 & \\
\hline
\end{tabular}

These Malvem data are for the -325 mesh size fractions. 
Table A.7 Summary of Properties of the Pittsburgh \#8 (2) Coal.

\begin{tabular}{|c|c|c|c|c|c|c|c|c|}
\hline \multirow{3}{*}{\begin{tabular}{|l|} 
Analyses \\
Proximate
\end{tabular}} & \multicolumn{5}{|c|}{ Pittsburgh \#8 (2) } & & & \multirow{3}{*}{ cum. mass \% } \\
\hline & & & \multicolumn{3}{|c|}{ Analyses } & \multirow{2}{*}{\multicolumn{2}{|c|}{ mass $\%$ in size bin }} & \\
\hline & Dry & As Rec'd & Size Distribu & tion & Sieves & & & \\
\hline Fixed Carbon & 56.87 & 55.92 & \multirow{3}{*}{\multicolumn{2}{|c|}{$\begin{array}{c}d p>600 \mu \mathrm{m} \\
600 \mu \mathrm{m}>d p>300 \mu \mathrm{m} \\
300 \mu \mathrm{m}>d p>149 \mu \mathrm{m}\end{array}$}} & +28 & & 0.00 & 0.00 \\
\hline Volatile Matter & 36.58 & 35.97 & & & $28 \times 48$ & & 0.27 & 0.27 \\
\hline Moisture & \multicolumn{2}{|l|}{1.67} & & & $48 \times 100$ & & 1.40 & 1.67 \\
\hline Uitimate & Dry & As Rec'd & \multicolumn{2}{|c|}{$149 \mu m>d p>74 \mu m$} & $100 \times 200$ & & 27.83 & 29.50 \\
\hline$c$ & 78.62 & 77.31 & \multicolumn{2}{|c|}{$74 \mu \mathrm{m}>\mathrm{dp}>44 \mu \mathrm{m}$} & $200 \times 325$ & & 30.83 & 60.33 \\
\hline$H$ & 5.14 & 5.06 & \multicolumn{2}{|c|}{$44 \mu m>d p$} & -325 & & 39.67 & 100.00 \\
\hline 0 & 6.51 & 6.41 & \multicolumn{3}{|c|}{ Size Distribution (Malvem) } & \multicolumn{3}{|c|}{ Size Distribution (Malvem) } \\
\hline$N$ & 1.50 & 1.48 & Diameter : & in & cum. vol. & Diameter & $\%$ in & cum vol. \\
\hline $\mathrm{s}$ & 1.57 & 1.54 & $(\mathrm{um})$ & size bin & per. & $(\mu \mathrm{m})$ & size bin & per. \\
\hline $\mathrm{Cl}$ & 0.10 & 0.09 & $188 \mathrm{~m}$ & 0.00 & 100.0 & $118.4 \mathrm{~m} 2$ & 0.08 & 99.9 \\
\hline Ash & 6.63 & 6.51 & $162 m$ & 0.00 & 100.0 & $102.1 \mathrm{~m} 2$ & 0.15 & 99.9 \\
\hline Ash Chemistry & $\%$ dry fuel & $\%$ ash & $140 \mathrm{~m}$ & 0.00 & 100.0 & $88.1 \mathrm{~m} 2$ & 0.18 & 99.8 \\
\hline $\mathrm{SiO} 2$ & 3.16 & 47.70 & $121 \mathrm{~m}$ & 0.00 & 100.0 & $76 \mathrm{~m} 2$ & 0.13 & 99.9 \\
\hline $\mathrm{Al} 2 \mathrm{O} 3$ & 1.60 & 24.08 & $104 m$ & 0.00 & 100.0 & $65.6 \mathrm{~m} 2$ & 1.33 & 98.7 \\
\hline$T_{1 O 2}$ & 0.07 & 1.05 & $89.9 m$ & 0.25 & 99.8 & $56.6 \mathrm{~m} 2$ & 5.30 & 94.7 \\
\hline $\mathrm{Fe} 2 \mathrm{O3}$ & 1.11 & 16.81 & $77.5 \mathrm{~m}$ & 0.40 & 99.4 & $48.8 \mathrm{~m} 2$ & 9.88 & 90.1 \\
\hline $\mathrm{CaO}$ & 0.23 & 3.46 & $66.9 \mathrm{~m}$ & 0.35 & 99.0 & $42.1 \mathrm{~m} 2$ & 11.45 & 88.6 \\
\hline MgO & 0.06 & 0.84 & $57.7 \mathrm{~m}$ & 1.05 & 98.0 & $38.3 \mathrm{~m} 2$ & 10.03 & 90.0 \\
\hline $\mathrm{K} 2 \mathrm{O}$ & 0.12 & 1.75 & $49.8 m$ & 5.35 & 92.6 & $31.3 \mathrm{~m} 2$ & 8.03 & 92.0 \\
\hline $\mathrm{Na} 2 \mathrm{O}$ & 0.03 & 0.45 & $42.9 \mathrm{~m}$ & 9.45 & 83.2 & $27 \mathrm{~m} 2$ & 8.00 & 92.0 \\
\hline SO3 & 0.20 & 2.99 & $37.1 \mathrm{~m}$ & 12.60 & 70.6 & $23.3 \mathrm{~m} 2$ & 8.88 & 91.1 \\
\hline $\mathrm{P} 2 \mathrm{O5}$ & 0.04 & 0.62 & $32 \mathrm{~m}$ & 11.95 & 58.6 & $20.1 \mathrm{~m} 2$ & 7.23 & 92.8 \\
\hline $\mathrm{Cl}$ & & & $27.6 \mathrm{~m}$ & 8.55 & 50.1 & $17.4 \mathrm{~m}^{2}$ & 4.43 & 95.6 \\
\hline Undetermined & 0.01 & 0.23 & $23.8 \mathrm{~m}$ & 6.60 & 43.5 & $15 \mathrm{~m} 2$ & 3.70 & 96.3 \\
\hline Total & 6.62 & 100.0 & $20.5 \mathrm{~m}$ & 6.00 & 37.5 & $12.9 \mathrm{~m} 2$ & 4.40 & 95.6 \\
\hline \multicolumn{3}{|c|}{ Forms of Sulfur ( $\%$ dry fuel) } & $17.7 \mathrm{~m}$ & 6.35 & 31.1 & $11.1 \mathrm{~m} 2$ & 3.90 & 96.1 \\
\hline Pyritic & \multicolumn{2}{|c|}{0.69} & $15.3 \mathrm{~m}$ & 6.40 & 24.7 & $9.6 \mathrm{~m} 2$ & 2.88 & 97.1 \\
\hline Organic & \multicolumn{2}{|c|}{0.82} & $13.2 \mathrm{~m}$ & 5.25 & 19.5 & $8.3 m 2$ & 1.63 & 98.4 \\
\hline Sulfatic & \multicolumn{2}{|c|}{0.05} & $11.4 \mathrm{~m}$ & 4.05 & 15.4 & $7.2 \mathrm{~m} 2$ & 1.45 & 98.6 \\
\hline Fraction Free Silica & 0.24 & & $9.8 \mathrm{~m}$ & 2.85 & 12.6 & $6.2 \mathrm{~m} 2$ & 1.50 & 98.5 \\
\hline Fraction Pyritic Iron & 0.74 & & $8.5 \mathrm{~m}$ & 2.25 & 10.3 & $5.3 \mathrm{~m} 2$ & 1.33 & 98.7 \\
\hline Heating Value (Btu/hb, & & & $7.3 \mathrm{~m}$ & 2.00 & 8.3 & $4.8 \mathrm{~m} 2$ & 1.20 & 98.8 \\
\hline As Fired & 13994 & 13761 & $6.3 m$ & 1.80 & 6.5 & $4 \mathrm{~m} 2$ & 0.93 & 99.1 \\
\hline Dulong & 14184 & 13947 & $5.4 m$ & 1.65 & 4.9 & $3.4 \mathrm{~m} 2$ & 0.88 & 99.1 \\
\hline Acid Sol. Alkali (ppm) & Dry & As Rec'd & $4.7 \mathrm{~m}$ & 1.35 & 3.5 & $3 m 2$ & 0.70 & 99.3 \\
\hline $\mathrm{Na}$ & & & $4.1 \mathrm{~m}$ & 0.90 & 2.6 & $2.8 \mathrm{~m} 2$ & 0.30 & 99.7 \\
\hline $\mathrm{Mg}$ & & & $3.5 m$ & 0.80 & 1.8 & $2.2 m 2$ & 0.13 & 99.9 \\
\hline $\mathrm{Ca}$ & & & $3 m$ & 0.50 & 1.3 & $1.9 \mathrm{~m} 2$ & 0.00 & 100.0 \\
\hline $\mathrm{K}$ & & & $2.6 \mathrm{~m}$ & 0.35 & 1.0 & $1.6 \mathrm{~m} 2$ & 0.05 & 100.0 \\
\hline Fusion Temp. & ${ }^{\circ} \mathrm{F}$ & ${ }^{\circ} \mathrm{C}$ & $2.2 \mathrm{~m}$ & 0.25 & 0.7 & $1.4 \mathrm{~m} 2$ & 0.00 & 100.0 \\
\hline Reducing Conditions & & & $1.9 \mathrm{~m}$ & 0.55 & 0.2 & $1.2 \mathrm{~m} 2$ & 0.00 & 100.0 \\
\hline Initial Deformation & 2109 & 1154 & & Size Stati & s (Malven & Data Only) & & \\
\hline Spherical & 2268 & 1242 & & & & & Malvern & All Data \\
\hline Hemispherical & 2383 & 1306 & Dv. 5 & Volume $\mathrm{M}$ & Diam. & & 24.78 & \\
\hline Fluid & 2481 & 1360 & Dv.9 & $90 \%$ volu & diameter & & 44.78 & \\
\hline Oxidizing Conditions & & & Dv.1 & 10 percen & volume $\mathrm{d}$ & imeter & 18.55 & \\
\hline Initial Deformation & 2472 & 1356 & $\mathrm{D} 4,3$ & & & & 25.52 & \\
\hline Spherical & 2519 & 1382 & D3,2 & Sauter Me & Diameter & & 14.80 & \\
\hline Hemispherical & 2550 & 1399 & Span & & & & 1.48 & \\
\hline Fluid & 2604 & 1429 & Specific Su & Iface Area & $3 /(c)$ & & 0.39 & \\
\hline
\end{tabular}

These Malvem data are for the -325 mesh size fractions. 
Table A.8 Summary of Properties of the Massey Sprouce Coal.

Massey Sprouce

\begin{tabular}{|c|c|c|c|c|c|c|c|c|}
\hline Analyses & & & \multicolumn{3}{|c|}{ Analyses } & & & \\
\hline Proximate & Dry & As Rec'd & Size Distribu & tion & Sieves & \multicolumn{2}{|c|}{ mass $\%$ in size bin } & cum. mass $\%$ \\
\hline Fixed Carbon & 56.99 & 55.69 & \multirow{6}{*}{\multicolumn{2}{|c|}{$\begin{array}{c}d p>600 \mu m \\
600 \mu m>d p>300 \mu m \\
300 \mu m>d p>149 \mu m \\
149 \mu m>d p>74 \mu m \\
74 \mu m>d p>44 \mu m \\
44 \mu m>d p\end{array}$}} & +28 & & & \\
\hline Volatile Matter & 34.68 & 33.89 & & & $28 \times 48$ & & & \\
\hline Moisture & \multicolumn{2}{|c|}{2.28} & & & $48 \times 100$ & & & \\
\hline Ultimate & Dry & As Rec'd & & & $100 \times 200$ & & & \\
\hline $\mathrm{C}$ & 77.89 & 76.11 & & & $200 \times 325$ & & & \\
\hline$H$ & 5.04 & 4.93 & & & -325 & & & \\
\hline $\mathrm{O}$ & 6.26 & 6.12 & \multicolumn{3}{|c|}{ Size Distribution (Malvern) } & \multicolumn{3}{|c|}{ Size Distribution (Malvem) } \\
\hline$N$ & 1.43 & 1.40 & \multirow{2}{*}{\multicolumn{2}{|c|}{$\begin{array}{c}\text { Diameter of in } \\
(\mu \mathrm{m})\end{array} \quad$ size bin }} & cum. vol. & Diameter & $\%$ in & cum. vol. \\
\hline$S$ & 1.05 & 1.03 & & & per. & $(\mu \mathrm{m})$ & size bin & per. \\
\hline $\mathrm{Cl}$ & & & \multirow{3}{*}{$\begin{array}{l}188 \mathrm{~m} \\
162 \mathrm{~m} \\
140 \mathrm{~m}\end{array}$} & & & \multirow{3}{*}{$\begin{array}{c}118.4 \mathrm{~m} 2 \\
102.1 \mathrm{~m} 2 \\
88.1 \mathrm{~m} 2\end{array}$} & & \\
\hline Ash & 8.33 & 8.14 & & & & & & \\
\hline Ash Chemistry & $\%$ dry fuel & $\%$ ash & & & & & & \\
\hline $\mathrm{SiO} 2$ & 4.61 & 55.35 & $121 \mathrm{~m}$ & & & $76 \mathrm{~m} 2$ & & \\
\hline Al2O3 & 2.18 & 26.22 & $104 m$ & & & $65.6 \mathrm{~m} 2$ & & \\
\hline TOO2 & 0.10 & 1.23 & $89.9 m$ & & & $56.6 \mathrm{~m} 2$ & & \\
\hline $\mathrm{Fe} 2 \mathrm{O} 3$ & 0.97 & 11.62 & $77.5 \mathrm{~m}$ & & & $48.8 \mathrm{~m} 2$ & & \\
\hline $\mathrm{CaO}$ & 0.12 & 1.42 & $66.9 m$ & & & $42.1 \mathrm{~m} 2$ & & \\
\hline $\mathrm{MgO}$ & 0.07 & 0.86 & $57.7 \mathrm{~m}$ & & & $38.3 m^{2}$ & & \\
\hline $\mathrm{K} 2 \mathrm{O}$ & 0.19 & 2.28 & $49.8 m$ & & & $31.3 \mathrm{~m} 2$ & & \\
\hline $\mathrm{Na} 2 \mathrm{O}$ & 0.02 & 0.29 & $42.9 m$ & & & $27 \mathrm{~m} 2$ & & \\
\hline $\mathrm{SO3}$ & 0.15 & 1.76 & $37.1 \mathrm{~m}$ & & & $23.3 \mathrm{~m}^{2}$ & & \\
\hline $\mathrm{P} 205$ & 0.01 & 0.08 & $32 m$ & & & $20.1 \mathrm{~m} 2$ & & \\
\hline Cl & & & $27.6 \mathrm{~m}$ & & & $17.4 \mathrm{~m} 2$ & & \\
\hline Undetermined & -0.09 & -1.11 & $23.8 \mathrm{~m}$ & & & $15 \mathrm{~m} 2$ & & \\
\hline Total & 8.33 & 100.0 & $20.5 m$ & & & $12.9 \mathrm{~m} 2$ & & - \\
\hline \multicolumn{3}{|c|}{ Forms of Sulfur ( $\%$ dry fuel) } & $17.7 \mathrm{~m}$ & & & $11.1 \mathrm{~m} 2$ & & \\
\hline Pyritic & \multicolumn{2}{|c|}{0.49} & $15.3 \mathrm{~m}$ & & & $9.6 \mathrm{~m} 2$ & & \\
\hline Organic & \multicolumn{2}{|c|}{0.53} & $13.2 \mathrm{~m}$ & & & $8.3 m 2$ & & \\
\hline Sulfatic & \multicolumn{2}{|c|}{0.03} & $11.4 \mathrm{~m}$ & & & $7.2 \mathrm{~m} 2$ & & . \\
\hline Fraction Free Silica & \multicolumn{2}{|c|}{0.29} & $9.8 \mathrm{~m}$ & & & $6.2 \mathrm{~m} 2$ & & \\
\hline Fraction Pyritic Iron & \multicolumn{2}{|c|}{0.63} & $8.5 m$ & & & $5.3 \mathrm{~m} 2$ & & \\
\hline \multicolumn{3}{|c|}{ Heating Value (Btu/hb, dry) } & $7.3 m$ & & & $4.8 \mathrm{~m} 2$ & & \\
\hline As Fired & 13768 & 13454 & $6.3 m$ & & & $4 m 2$ & & \\
\hline Dulong & 14012 & 13692 & $5.4 \mathrm{~m}$ & & & $3.4 \mathrm{~m} 2$ & & \\
\hline Acid Sol. Alkali (ppm) & Dry & As Rec'd & $4.7 m$ & & & $3 m 2$ & & \\
\hline \multirow{4}{*}{\multicolumn{3}{|c|}{$\begin{array}{l}\mathrm{Na} \\
\mathrm{Mg} \\
\mathrm{Ca} \\
\mathrm{K} \\
\end{array}$}} & $4.1 \mathrm{~m}$ & & & $2.8 \mathrm{~m} 2$ & & \\
\hline & & & $3.5 \mathrm{~m}$ & & & $2.2 \mathrm{~m} 2$ & & \\
\hline & & & $3 m$ & & & $1.9 \mathrm{~m} 2$ & & \\
\hline & & & $2.6 \mathrm{~m}$ & & & $1.6 \mathrm{~m} 2$ & & \\
\hline Fusion Temp. & ${ }^{\circ} \mathrm{F}$ & ${ }^{\circ} \mathrm{C}$ & $2.2 m$ & & & $1.4 \mathrm{~m} 2$ & & \\
\hline \multirow{2}{*}{$\begin{array}{l}\text { Reducing Conditions } \\
\text { Initial Deformation }\end{array}$} & & & $1.9 \mathrm{~m}$ & & & $1.2 \mathrm{~m} 2$ & & \\
\hline & & & \multicolumn{6}{|c|}{ Size Statistics (Malvern Data Only) } \\
\hline Spherical & & & & & & & Malvern & All Data \\
\hline Hemispherical & & & Dv.5 & Volume M & Diam. & & & \\
\hline Fluid & & & Dv.9 & $90 \%$ volur & diameter & & & \\
\hline Oxidizing Conditions & & & Dv.1 & 10 percent & volume d & meter & & \\
\hline Initial Deformation & & & D4,3 & & & & & \\
\hline Spherical & & & D3,2 & Sauter Me & Diameter & & & \\
\hline Hemispherical & & & Span & & & & & \\
\hline Fluid & & & Specific Su & face Area & $3 / c c)$ & & & \\
\hline
\end{tabular}

These Malvern data are for the -325 mesh size fractions. 
Table A.9 Summary of Properties of the Eastern Kentucky Coal.

Eastern Kentucky

\begin{tabular}{|c|c|c|c|c|c|c|c|c|}
\hline \multirow{2}{*}{\begin{tabular}{|l|}
\multicolumn{2}{|c|}{ Analyses } \\
Proximate \\
\end{tabular}} & \multirow[b]{2}{*}{ Dry } & \multirow[b]{2}{*}{ As Rec'd } & \multicolumn{3}{|c|}{ Analyses } & \multirow{2}{*}{\multicolumn{2}{|c|}{ mass $\%$ in size bin }} & \multirow[b]{2}{*}{ cum. mass \% } \\
\hline & & & \multicolumn{2}{|c|}{ Size Distribution } & Sieves & & & \\
\hline Fixed Carbon & 53.00 & 52.28 & \multirow{3}{*}{\multicolumn{2}{|c|}{$\begin{array}{c}d p>600 \mu m \\
600 \mu m>d p>300 \mu m \\
300 \mu m>d p>149 \mu m\end{array}$}} & +28 & \multicolumn{2}{|c|}{0.00} & 0.00 \\
\hline Volatile Matter & 36.87 & 36.37 & & & $28 \times 48$ & \multirow{2}{*}{\multicolumn{2}{|c|}{$\begin{array}{l}0.05 \\
1.43\end{array}$}} & 0.05 \\
\hline Moisture & \multicolumn{2}{|l|}{1.36} & & & $48 \times 100$ & & & 1.48 \\
\hline Ultimate & Dry & As Rec'd & \multicolumn{2}{|c|}{$149 \mu m>d p>74 \mu m$} & $100 \times 200$ & \multicolumn{2}{|r|}{32.50} & 33.98 \\
\hline C & 74.82 & 73.80 & \multicolumn{2}{|c|}{$74 \mu m>d p>44 \mu m$} & $200 \times 325$ & & 30.15 & 64.13 \\
\hline H & 4.97 & 4.90 & \multicolumn{2}{|c|}{$44 \mu \mathrm{m} \times \mathrm{dp}$} & -325 & & 35.88 & 100.00 \\
\hline 0 & 7.57 & 7.47 & \multicolumn{3}{|c|}{ Size Distribution (Malvem) } & \multicolumn{3}{|c|}{ Size Distribution (Malvem) } \\
\hline N & 1.46 & 1.44 & Diameiter: & in & cum. vol. & Diameter & $\%$ in & curn. vol. \\
\hline S & 0.97 & 0.96 & $(\mu \mathrm{m})$ & size bin & per. & $(\mu \mathrm{m})$ & size bin & per. \\
\hline $\mathrm{Cl}$ & 0.09 & 0.09 & $188 \mathrm{~m}$ & 0.00 & 100.0 & $118.4 \mathrm{~m} 2$ & 0.05 & 100.0 \\
\hline Ash & 10.15 & 10.02 & $162 \mathrm{~m}$ & 0.05 & 100.0 & $102.1 \mathrm{~m} 2$ & 0.13 & 99.9 \\
\hline Ash Chemistry & $\%$ dry fuel & $\%$ ash & $140 \mathrm{~m}$ & 0.05 & 99.9 & $88.1 \mathrm{~m} 2$ & 0.15 & 99.9 \\
\hline $\mathrm{SiO} 2$ & 5.86 & 57.67 & $121 \mathrm{~m}$ & 0.05 & 99.9 & $76 \mathrm{~m} 2$ & 0.23 & 99.8 \\
\hline $\mathrm{Al} 2 \mathrm{O} 3$ & 3.09 & 30.39 & $104 \mathrm{~m}$ & 0.05 & 99.8 & $65.6 \mathrm{~m} 2$ & 1.98 & 98.0 \\
\hline THO2 & 0.21 & 2.06 & $89.9 \mathrm{~m}$ & 0.18 & 99.6 & $56.6 \mathrm{~m} 2$ & 5.58 & 94.4 \\
\hline $\mathrm{Fe} 2 \mathrm{O} 3$ & 0.49 & 4.83 & $77.5 \mathrm{~m}$ & 0.63 & 99.0 & $48.8 \mathrm{~m} 2$ & 9.70 & 90.3 \\
\hline $\mathrm{CaO}$ & 0.12 & 1.15 & $66.9 \mathrm{~m}$ & 1.48 & 97.5 & $42.1 \mathrm{~m} 2$ & 10.70 & 89.3 \\
\hline $\mathrm{MgO}$ & 0.04 & 0.41 & $57.7 m$ & 2.98 & 94.6 & $38.3 \mathrm{~m} 2$ & 8.63 & 91.4 \\
\hline $\mathrm{K} 20$ & 0.10 & 0.99 & $49.8 m$ & 5.85 & 88.7 & $31.3 \mathrm{~m} 2$ & 6.40 & 93.6 \\
\hline $\mathrm{Na} 2 \mathrm{O}$ & 0.02 & 0.17 & $42.9 \mathrm{~m}$ & 8.43 & 80.3 & $27 \mathrm{~m} 2$ & 6.98 & 93.0 \\
\hline $\mathrm{SO} 3$ & 0.13 & 1.28 & $37.1 \mathrm{~m}$ & 9.73 & 70.6 & $23.3 \mathrm{~m} 2$ & 8.98 & 91.0 \\
\hline P2O5 & 0.01 & 0.13 & $32 \mathrm{~m}$ & 9.08 & 61.5 & $20.1 \mathrm{~m} 2$ & 7.55 & 92.5 \\
\hline $\mathrm{Cl}$ & & & $27.6 m$ & 7.48 & 54.0 & $17.4 \mathrm{~m} 2$ & 4.28 & 95.7 \\
\hline Undetermined & 0.09 & 0.91 & $23.8 \mathrm{~m}$ & 6.40 & 47.6 & $15 \mathrm{~m} 2$ & 3.30 & 96.7 \\
\hline Total & 10.15 & 100.0 & $20.5 m$ & 5.73 & 41.9 & $12.9 \mathrm{~m} 2$ & 4.13 & 95.9 \\
\hline Forms of Sulfur (\% dry & & & $17.7 \mathrm{~m}$ & 5.35 & 36.5 & $11.1 \mathrm{~m} 2$ & 4.35 & 95.7 \\
\hline Pyritic & 0.31 & & $15.3 \mathrm{~m}$ & 5.30 & 31.2 & $9.6 \mathrm{~m} 2$ & 3.90 & 96.1 \\
\hline Organic & 0.66 & & $13.2 \mathrm{~m}$ & 4.95 & 26.3 & $8.3 \mathrm{~m} 2$ & 2.40 & 97.6 \\
\hline Sulfatic & 0.00 & & $11.4 \mathrm{~m}$ & 4.18 & 22.1 & $7.2 \mathrm{~m} 2$ & 1.63 & 98.4 \\
\hline Fraction Free Silica & 0.21 & & $9.8 m$ & 3.33 & 18.8 & $6.2 \mathrm{~m} 2$ & 1.68 & 98.3 \\
\hline Fraction Pyritic Iron & 0.78 & & $8.5 \mathrm{~m}$ & 2.75 & 16.0 & $5.3 \mathrm{~m} 2$ & 1.78 & 98.2 \\
\hline Heating Value (Btu/lb, & & & $7.3 \mathrm{~m}$ & 2.50 & 13.5 & $4.8 \mathrm{~m} 2$ & 1.60 & 98.4 \\
\hline As Fired & 13226 & 13046 & $6.3 m$ & 2.48 & 11.1 & $4 \mathrm{~m} 2$ & 1.40 & 98.6 \\
\hline Dulong & 13418 & 13235 & $5.4 \mathrm{~m}$ & 2.43 & 8.6 & $3.4 \mathrm{~m} 2$ & 1.15 & 98.9 \\
\hline Acid Sol. Alkali (ppm) & Dry & As Rec'd & $4.7 \mathrm{~m}$ & 2.13 & 6.5 & $3 \mathrm{~m} 2$ & 0.93 & 99.1 \\
\hline $\mathrm{Na}$ & & & $4.1 \mathrm{~m}$ & 1.65 & 4.9 & $2.8 \mathrm{~m} 2$ & 0.45 & 99.6 \\
\hline $\mathrm{Mg}$ & & & $3.5 \mathrm{~m}$ & 1.35 & 3.5 & $2.2 \mathrm{~m} 2$ & 0.15 & 99.9 \\
\hline $\mathrm{Ca}$ & & & $3 m$ & 0.93 & 2.6 & $1.9 \mathrm{~m} 2$ & 0.00 & 100.0 \\
\hline$K$ & & & $2.6 \mathrm{~m}$ & 0.65 & 1.9 & $1.6 \mathrm{~m} 2$ & 0.00 & 100.0 \\
\hline Fusion Temp. & ${ }^{\circ} \mathrm{F}$ & $\infty$ & $2.2 \mathrm{~m}$ & 0.58 & 1.4 & $1.4 \mathrm{~m} 2$ & 0.00 & 100.0 \\
\hline Reducing Conditions & & $\cdots$ & $1.9 \mathrm{~m}$ & 0.60 & 0.8 & $1.2 \mathrm{~m} 2$ & 0.00 & 100.0 \\
\hline Initial Deformation & 2949 & 1620 & & Size Stati & $s$ (Malver & Data Only) & & \\
\hline Spherical & 2980 & 1638 & & & & & Malvern & All Data \\
\hline Hemispherical & 2992 & 1644 & Dv.5 & Volume $M$ & Diam. & & 23.48 & \\
\hline Fluid & 3000 & 1649 & Dv.9 & $90 \%$ volu & diameter & & 47.54 & \\
\hline Oxidizing Conditions & & & Dv.1 & 10 percen & volume d & meter & 6.28 & \\
\hline Initial Deformation & 2960 & 1627 & D4.3 & & & & 25.23 & \\
\hline Spherical & 2996 & 1647 & D3,2 & Sauter Me & Diameter & & 13.04 & \\
\hline Hemispherical & 3000 & 1649 & Span & & & & 1.75 & $\cdot$ \\
\hline Fluid & 3000 & 1649 & Specific Su & Iface Area & $3 / c c)$ & & 0.45 & \\
\hline
\end{tabular}

These Malvem data are for the -325 mesh size fractions. 
Table A.10 Summary of Properties of the Pittsbugh \#8 (1) Coal.

Pittsburgh \#8 (1)

\begin{tabular}{|c|c|c|c|c|c|c|c|c|}
\hline \multirow{2}{*}{\begin{tabular}{|l|}
\multicolumn{1}{|c|}{ Analyses } \\
Proximate \\
\end{tabular}} & & & \multicolumn{3}{|c|}{ Analyses } & \multirow{2}{*}{\multicolumn{2}{|c|}{ mass $\%$ in size bin }} & \multirow[b]{2}{*}{ cum. mass: } \\
\hline & Dry & As Rec'd & \multicolumn{2}{|c|}{ Size Distribution } & Sieves & & & \\
\hline Fixed Carbon & 49.16 & 48.66 & \multirow{3}{*}{\multicolumn{2}{|c|}{$\begin{array}{c}d p>600 \mu m \\
600 \mu m>d p>300 \mu m \\
300 \mu m>d p>149 \mu m\end{array}$}} & +28 & & 0.00 & 0.00 \\
\hline Volatile Matter & 40.16 & 39.75 & & & $28 \times 48$ & & 0.20 & 0.20 \\
\hline Moisture & \multicolumn{2}{|c|}{1.02} & & & $48 \times 100$ & & 0.80 & 1.00 \\
\hline Uitimate & Dry & As Recid & $149 \mu \mathrm{m}>d \mathrm{p}$ & $\$ 74 \mu \mathrm{m}$ & $100 \times 200$ & & 22.10 & 23.10 \\
\hline c & 71.51 & 70.78 & $74 \mu m>d \rho>$ & $>44 \mu \mathrm{m}$ & $200 \times 325$ & & 34.80 & 57.90 \\
\hline$H$ & 5.03 & 4.98 & $44 \mu \mathrm{m}>$ & & .325 & & 42.10 & 100.00 \\
\hline 0 & 6.76 & 6.69 & \multicolumn{3}{|c|}{ Size Distribution (Malvem) } & \multicolumn{3}{|c|}{ Size Distribution (Malvem) ${ }^{*}$} \\
\hline$N$ & 1.24 & 1.23 & \multirow{2}{*}{\multicolumn{2}{|c|}{\begin{tabular}{c|c}
$\begin{array}{c}\text { Diameter of in } \\
(\mu \mathrm{m})\end{array}$ & size bin \\
\end{tabular}}} & cum. vol. & Diameter & $\%$ in & cum. vol. \\
\hline $\mathrm{s}$ & 4.78 & 4.73 & & & per. & $(\mu \mathrm{m})$ & size bin & per. \\
\hline $\mathrm{Cl}$ & & & \multirow{3}{*}{$\begin{array}{l}188 \mathrm{~m} \\
162 \mathrm{~m} \\
140 \mathrm{~m}\end{array}$} & & & \multirow{3}{*}{$\begin{array}{c}118.4 \mathrm{~m} 2 \\
102.1 \mathrm{~m} 2 \\
88.1 \mathrm{~m} 2\end{array}$} & & \\
\hline Ash & 10.68 & 10.57 & & & & & & \\
\hline Ash Chemistry & $\%$ dry fuel & $\%$ ash & & & & & & \\
\hline $\mathrm{SiO} 2$ & 4.42 & 41.40 & $121 \mathrm{~m}$ & & & $76 \mathrm{~m} 2$ & & \\
\hline $\mathrm{Al} 2 \mathrm{O} 3$ & 2.19 & 20.51 & $104 m$ & & & $65.6 \mathrm{~m} 2$ & & \\
\hline TIO2 & 0.10 & 0.89 & $89.9 m$ & & & $56.6 \mathrm{~m} 2$ & & \\
\hline $\mathrm{Fe} 2 \mathrm{O3}$ & 3.10 & 29.03 & $77.5 \mathrm{~m}$ & & & $48.8 \mathrm{~m} 2$ & & \\
\hline $\mathrm{CaO}$ & 0.22 & 2.07 & $66.9 \mathrm{~m}$ & & & $42.1 \mathrm{~m} 2$ & & \\
\hline $\mathrm{MgO}$ & 0.08 & 0.78 & $57.7 \mathrm{~m}$ & & & $38.3 \mathrm{~m} 2$ & & \\
\hline $\mathrm{K} 2 \mathrm{O}$ & 0.18 & 1.73 & $49.8 \mathrm{~m}$ & & & $31.3 \mathrm{~m} 2$ & & \\
\hline $\mathrm{Na} 2 \mathrm{O}$ & 0.04 & 0.40 & $42.9 m$ & & & $27 \mathrm{~m} 2$ & & \\
\hline $\mathrm{SO} 3$ & 0.25 & 2.33 & $37.1 \mathrm{~m}$ & & & $23.3 \mathrm{~m} 2$ & & \\
\hline P2O5 & 0.02 & 0.15 & $32 m$ & & & $20.1 \mathrm{~m} 2$ & & \\
\hline $\mathrm{Cl}$ & & & $27.6 \mathrm{~m}$ & & & $17.4 \mathrm{~m} 2$ & & \\
\hline Undetermined & 0.08 & 0.71 & $23.8 \mathrm{~m}$ & & & $15 \mathrm{~m} 2$ & & \\
\hline Total & 10.68 & 100.0 & $20.5 m$ & & & $12.9 \mathrm{~m} 2$ & & \\
\hline \multicolumn{3}{|c|}{ Forms of Sulfur (\% dry fuel) } & $17.7 \mathrm{~m}$ & & & $11.1 \mathrm{~m} 2$ & & \\
\hline Pyritic & \multicolumn{2}{|c|}{1.81} & $15.3 \mathrm{~m}$ & & & $9.6 \mathrm{~m} 2$ & & \\
\hline Organic & \multicolumn{2}{|c|}{2.82} & $13.2 \mathrm{~m}$ & & & $8.3 m 2$ & & \\
\hline Sulfatic & \multicolumn{2}{|c|}{0.15} & $11.4 \mathrm{~m}$ & & & $7.2 \mathrm{~m} 2$ & & \\
\hline Fraction Free Silica & \multirow{2}{*}{\multicolumn{2}{|c|}{$\begin{array}{l}0.26 \\
0.73\end{array}$}} & $9.8 \mathrm{~m}$ & & & $6.2 \mathrm{~m} 2$ & & \\
\hline Fraction Pyritic Iron & & & $8.5 \mathrm{~m}$ & & & $5.3 \mathrm{~m} 2$ & & \\
\hline \multicolumn{3}{|c|}{ Heating Value (Btu/lb, dry) } & $7.3 m$ & & & $4.8 \mathrm{~m} 2$ & & \\
\hline As Fired & 13004 & 12871 & $6.3 m$ & & & $4 \mathrm{~m} 2$ & & \\
\hline Dulong & 13190 & 13055 & $5.4 m$ & & & $3.4 \mathrm{~m} 2$ & & \\
\hline Acid Sol. Alkali (ppm) & Dry & As Rec'd & $4.7 \mathrm{~m}$ & & & $3 m 2$ & & \\
\hline \multirow{4}{*}{\multicolumn{3}{|c|}{$\begin{array}{l}\mathrm{Na} \\
\mathrm{Mg} \\
\mathrm{Ca} \\
\mathrm{K} \\
\end{array}$}} & $4.1 \mathrm{~m}^{\prime}$ & & & $2.8 \mathrm{~m} 2$ & & \\
\hline & & & $3.5 m$ & & & $2.2 \mathrm{~m} 2$ & & \\
\hline & & & $3 m$ & & & $1.9 \mathrm{~m} 2$ & & \\
\hline & & & $2.6 \mathrm{~m}$ & & & $1.6 \mathrm{~m} 2$ & & \\
\hline Fusion Temp. & ${ }^{\circ} \mathrm{F}$ & ${ }^{\circ} \mathrm{C}$ & $2.2 \mathrm{~m}$ & & & $1.4 \mathrm{~m} 2$ & & \\
\hline Reducing Conditions & & & $1.9 \mathrm{~m}$ & & & $1.2 \mathrm{~m} 2$ & & \\
\hline Initial Deformation & 1917 & 1047 & & Size Stat & s (Malver & Data Oniy) & & \\
\hline Spherical & 1980 & 1082 & & & & & Malvern & All Data \\
\hline Hemispherical & 2154 & 1179 & Dv.5 & Volume $M$ & Diam. & & & \\
\hline Fluid & 2232 & 1222 & Dv.9 & $90 \%$ volu & diameter & & & \\
\hline Oxidizing Conditions & & & Dv.1 & 10 percen & volume d & meter & & \\
\hline Initial Deformation & 2438 & 1337 & 04,3 & & & & & \\
\hline Spherical & 2502 & 1372 & $\mathrm{D} 3,2$ & Sauter Me & Diameter & & & \\
\hline Hemispherical & 2518 & 1381 & Span & & & & & \\
\hline Fluid & 2532 & 1389 & ISpecific Su & frace Area & $3 /(c)$ & & & \\
\hline
\end{tabular}

These Malvern data are for the -325 mesh size fractions. 
Table A.11 Summary of Properties of the Utah Blind Canyon Coal.

Utah Blind Canyon

\begin{tabular}{|c|c|c|c|c|c|c|c|c|}
\hline \multirow{2}{*}{\begin{tabular}{|l}
\multicolumn{2}{c}{ Analyses } \\
Proximate
\end{tabular}} & & & \multicolumn{3}{|c|}{ Anatyses } & & & \\
\hline & Dry & As Rec'd & Size Distribut & tion & Sieves & \multicolumn{2}{|c|}{ mass $\%$ in size bin } & cum. mass $\%$ \\
\hline Fixed Carbon & 45.59 & 44.12 & \multirow{3}{*}{\multicolumn{2}{|c|}{$\begin{array}{c}d p>600 \mu \mathrm{m} \\
600 \mu m>d p>300 \mu m \\
300 \mu m>d p>149 \mu m\end{array}$}} & +28 & & 0.00 & 0.00 \\
\hline Volatile Matter & 43.92 & 42.50 & & & $28 \times 48$ & & 0.33 & 0.33 \\
\hline Moisture & \multicolumn{2}{|c|}{3.24} & & & $48 \times 100$ & & 5.90 & 6.23 \\
\hline Ultimate & Dry & As Rec'd & \multicolumn{2}{|c|}{$149 \mu \mathrm{m}>d p>74 \mu \mathrm{m}$} & $100 \times 200$ & & 24.90 & 31.13 \\
\hline C & 72.62 & 70.27 & \multicolumn{2}{|c|}{$74 \mu m>0 p>44 \mu m$} & $200 \times 325$ & & 21.43 & 52.57 \\
\hline$H$ & 5.50 & 5.32 & \multicolumn{2}{|c|}{$44 \mu m>d p$} & -325 & & 47.43 & 100.00 \\
\hline 0 & 9.57 & 9.26 & \multicolumn{3}{|c|}{ Size Distribution (Malvem) } & \multicolumn{3}{|c|}{ Size Distribution (Malvern) ${ }^{*}$} \\
\hline$N$ & 1.33 & 1.29 & Diameter : & in & cum. vol. & Diameter & $\%$ in & cum. vol. \\
\hline s & 0.46 & 0.44 & $(\mu \mathrm{m})$ & size bin & per. & $(\mu \mathrm{m})$ & size bin & per. \\
\hline $\mathrm{Cl}$ & 0.04 & 0.04 & $188 m$ & 0.00 & 100.0 & $118.4 \mathrm{~m} 2$ & & \\
\hline Ash & 10.51 & 10.17 & $162 \mathrm{~m}$ & 0.00 & 100.0 & $102.1 \mathrm{~m} 2$ & & \\
\hline Ash Chemistry & $\%$ dry fuel & $\%$ ash & $140 m$ & 0.00 & 100.0 & $88.1 \mathrm{~m} 2$ & & \\
\hline $\mathrm{SiO} 2$ & 6.06 & 57.69 & $121 \mathrm{~m}$ & 0.00 & 100.0 & $76 \mathrm{~m}_{2}$ & & \\
\hline $\mathrm{Al} 2 \mathrm{O} 3$ & 1.92 & 18.32 & $104 m$ & 0.00 & 100.0 & $65.6 \mathrm{~m} 2$ & & \\
\hline TIO2 & 0.10 & 0.96 & $89.9 m$ & 0.08 & 99.9 & $56.6 \mathrm{~m} 2$ & & \\
\hline $\mathrm{Fe} 2 \mathrm{O} 3$ & 0.43 & 4.11 & $77.5 \mathrm{~m}$ & 0.28 & 99.7 & $48.8 \mathrm{~m} 2$ & & \\
\hline $\mathrm{CaO}$ & 0.64 & 6.13 & $66.9 \mathrm{~m}$ & 0.63 & 99.0 & $42.1 \mathrm{~m} 2$ & & \\
\hline $\mathrm{MgO}$ & 0.19 & 1.84 & $57.7 m$ & 1.35 & 97.7 & $38.3 \mathrm{~m} 2$ & & \\
\hline $\mathrm{K} 20$ & 0.12 & 1.16 & $49.8 \mathrm{~m}$ & 3.68 & 94.0 & $31.3 \mathrm{~m} 2$ & & \\
\hline $\mathrm{Na} 2 \mathrm{O}$ & 0.45 & 4.32 & $42.9 \mathrm{~m}$ & 7.55 & 86.5 & $27 \mathrm{~m} 2$ & & \\
\hline $\mathrm{SO} 3$ & 0.48 & 4.57 & $37.1 \mathrm{~m}$ & 9.68 & 76.8 & $23.3 \mathrm{~m} 2$ & & \\
\hline P2O5 & 0.03 & 0.33 & $32 m$ & 9.13 & 67.7 & $20.1 \mathrm{~m} 2$ & & \\
\hline $\mathrm{Cl}$ & & & $27.6 \mathrm{~m}$ & 7.45 & 60.2 & $17.4 \mathrm{~m} 2$ & & \\
\hline Undetermined & 0.06 & 0.58 & $23.8 \mathrm{~m}$ & 6.28 & 53.9 & $15 \mathrm{~m} 2$ & & . \\
\hline Total & 10.51 & 100.0 & $20.5 m$ & 5.78 & 48.2 & $12.9 \mathrm{~m} 2$ & & \\
\hline \multicolumn{3}{|c|}{ Forms of Sulfur ( $\%$ dry fuel) } & $17.7 m$ & 5.93 & 42.2 & $11.1 \mathrm{~m} 2$ & & \\
\hline Pyritic & \multicolumn{2}{|c|}{0.08} & $15.3 \mathrm{~m}$ & 6.05 & 36.2 & $9.6 \mathrm{~m} 2$ & & \\
\hline Organic & \multicolumn{2}{|c|}{0.37} & $13.2 \mathrm{~m}$ & 5.50 & 30.7 & $8.3 \mathrm{~m} 2$ & & \\
\hline Sulfatic & \multicolumn{2}{|c|}{0.00} & $11.4 \mathrm{~m}$ & 4.60 & 26.1 & $7.2 \mathrm{~m} 2$ & & \\
\hline Fraction Free Silica & \multicolumn{2}{|c|}{0.52} & $9.8 \mathrm{~m}$ & 3.68 & 22.4 & $6.2 \mathrm{~m} 2$ & & \\
\hline Fraction Pyritic Iron & \multicolumn{2}{|c|}{0.24} & $8.5 \mathrm{~m}$ & 3.15 & 19.3 & $5.3 \mathrm{~m} 2$ & & \\
\hline \multicolumn{3}{|c|}{ Heating Value (Btu/ $\mathrm{b}, \mathrm{dry})$} & $7.3 \mathrm{~m}$ & 3.00 & 16.3 & $4.8 \mathrm{~m} 2$ & & \\
\hline As Fired & 13108 & 12684 & $6.3 \mathrm{~m}$ & 2.95 & 13.3 & $4 \mathrm{~m}_{2}$ & & \\
\hline Dulong & 13247 & 12819 & $5.4 \mathrm{~m}$ & 2.78 & 10.5 & $3.4 \mathrm{~m} 2$ & & \\
\hline Acid Sol. Alkali (ppm) & Dry & As Rec'd & $4.7 \mathrm{~m}$ & 2.35 & 8.2 & $3 m 2$ & & \\
\hline $\mathrm{Na}$ & & & $4.1 \mathrm{~m}$ & 1.70 & 6.5 & $2.8 \mathrm{~m} 2$ & & \\
\hline $\mathrm{Mg}$ & & & $3.5 \mathrm{~m}$ & 1.45 & 5.0 & $2.2 \mathrm{~m} 2$ & & \\
\hline $\mathrm{Ca}$ & & & $3 m$ & 1.05 & 4.0 & $1.9 \mathrm{~m} 2$ & & \\
\hline $\mathrm{K}$ & & & $2.6 \mathrm{~m}$ & 0.88 & 3.1 & $1.6 \mathrm{~m} 2$ & & \\
\hline Fusion Temp. & ${ }^{\circ} \mathrm{F}$ & ${ }^{\circ} \mathrm{C}$ & $2.2 \mathrm{~m}$ & 0.83 & 2.3 & $1.4 \mathrm{~m} 2$ & & \\
\hline \multirow{2}{*}{$\begin{array}{r}\text { Reducing Conditions } \\
\text { Initial Deformation }\end{array}$} & \multirow[b]{2}{*}{2178} & & $1.9 \mathrm{~m}$ & 1.20 & 1.1 & $1.2 \mathrm{~m} 2$ & & \\
\hline & & 1192 & & Size Stat & is (Malver & Data Only) & & \\
\hline Spherical & 2246 & 1230 & & & & & Malvern & All Data \\
\hline Hemispherical & 2369 & 1298 & Dv.5 & Volume $\mathrm{M}$ & Diam. & & 20.25 & \\
\hline Fluid & 2641 & 1449 & Dv.9 & $90 \%$ volu & diameter & & 42.45 & \\
\hline Oxidizing Conditions & & & Dv.1 & 10 percen & volume $d$ & meter & 4.95 & \\
\hline Initial Deformation & 2220 & 1216 & $\mathrm{D} 4,3$ & & & & 22.58 & \\
\hline Spherical & 2265 & 1241 & $\mathrm{D} 3,2$ & Sauter Me & Diameter & & 10.88 & \\
\hline Hemispherical & 2400 & 1316 & Span & & & & 1.88 & \\
\hline Fluid & 2675 & 1468 & Specific Su & fface Area & $(3 / c c)$ & & 0.58 & \\
\hline
\end{tabular}

These Malvem data are for the -325 mesh size fractions. 
Table A.12 Summary of Properties of the Kentucky \#11 Coal.

Kentucky \#11

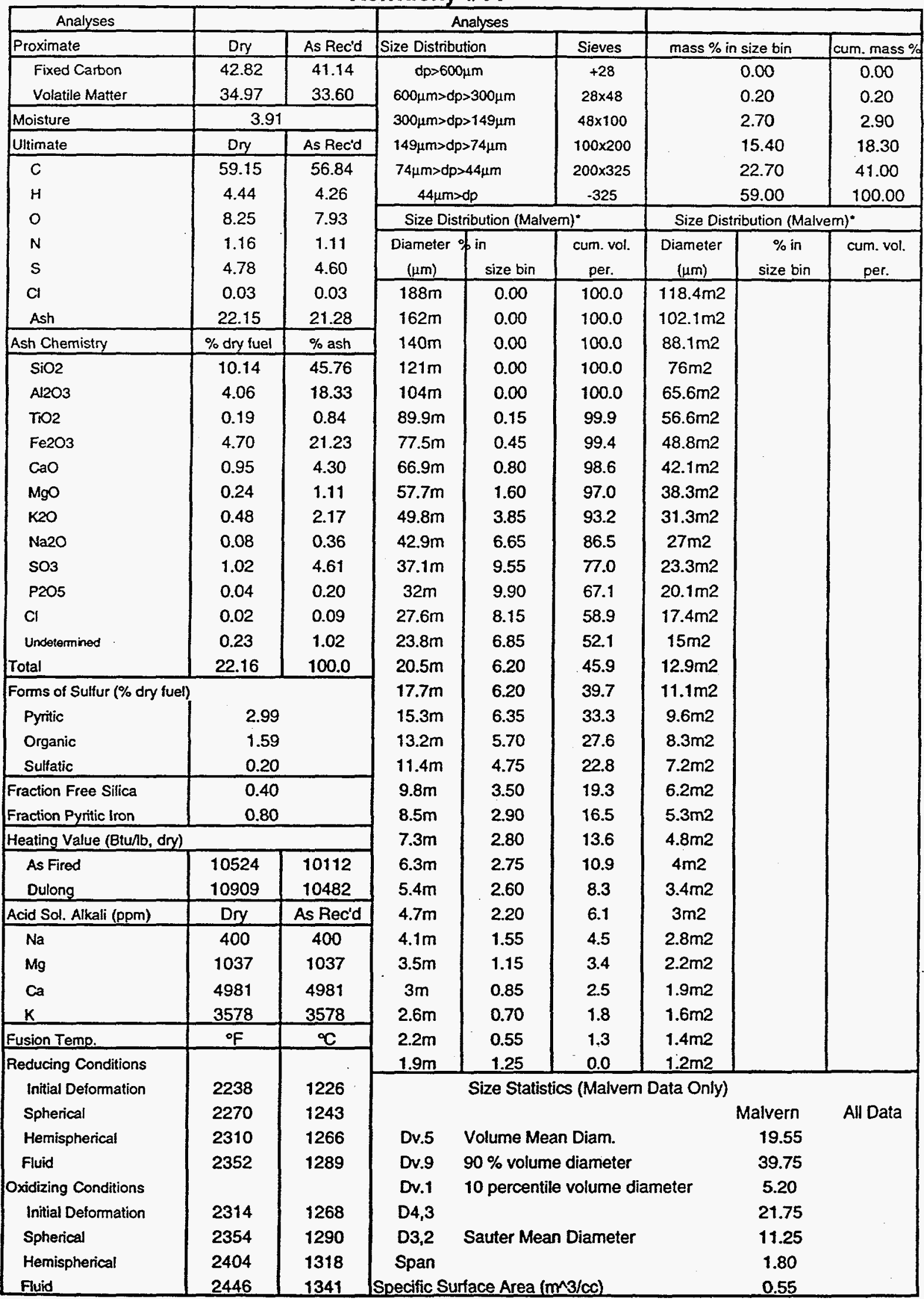

These Malvem data are for the -325 mesh size fractions. 
Table A.13 Summary of Properties of the Illinois \#6 (2) Coal.

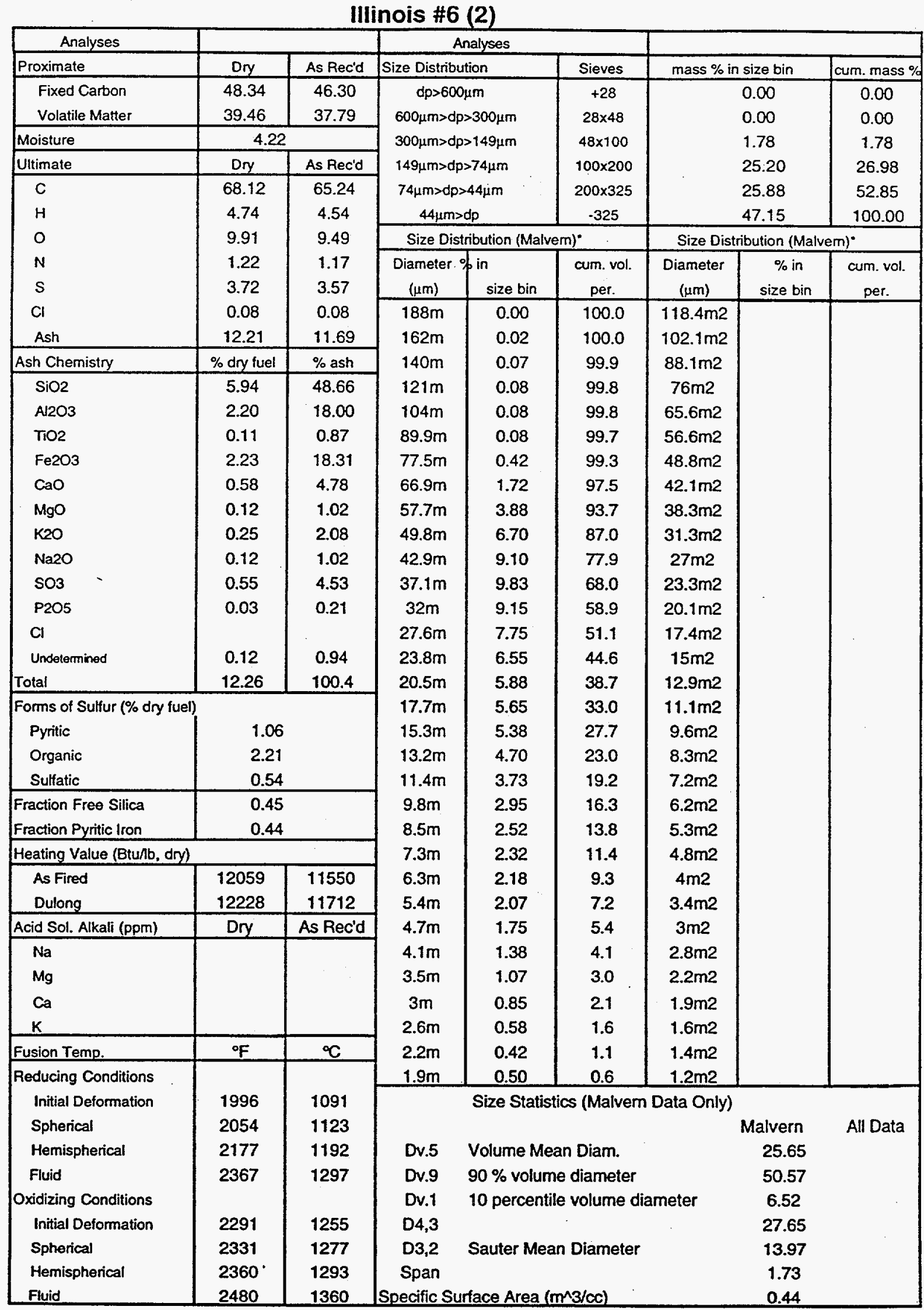

These Malvem data are for the -325 mesh size fractions. 
Table A.14 Summary of Properties of the SOAP.

Spherical Oil Agglomerate

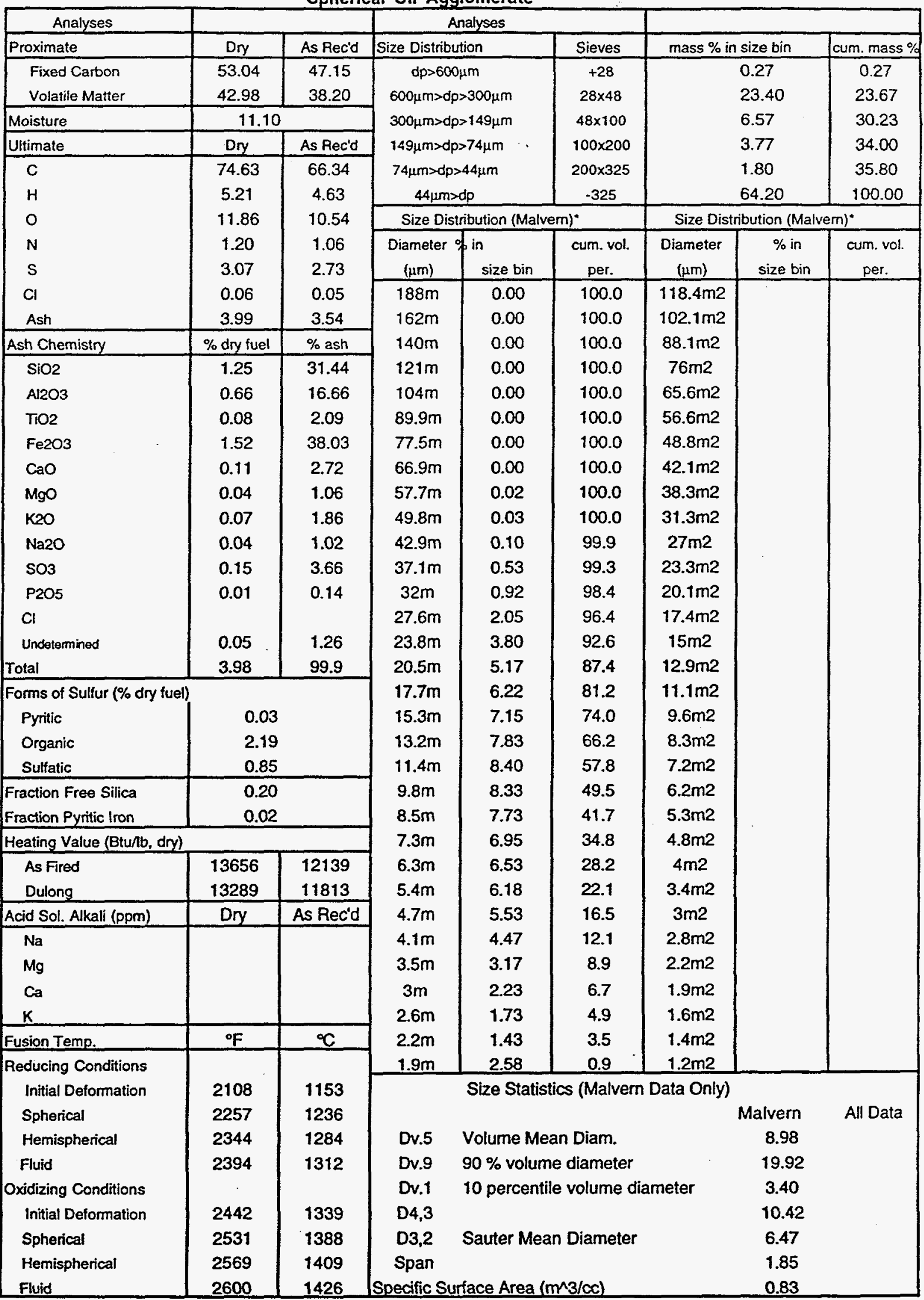

-These Malvern data are for the -325 mesh size fractions. 
Table A.15 Summary of Properties of the Kentucky \#9 Coal.

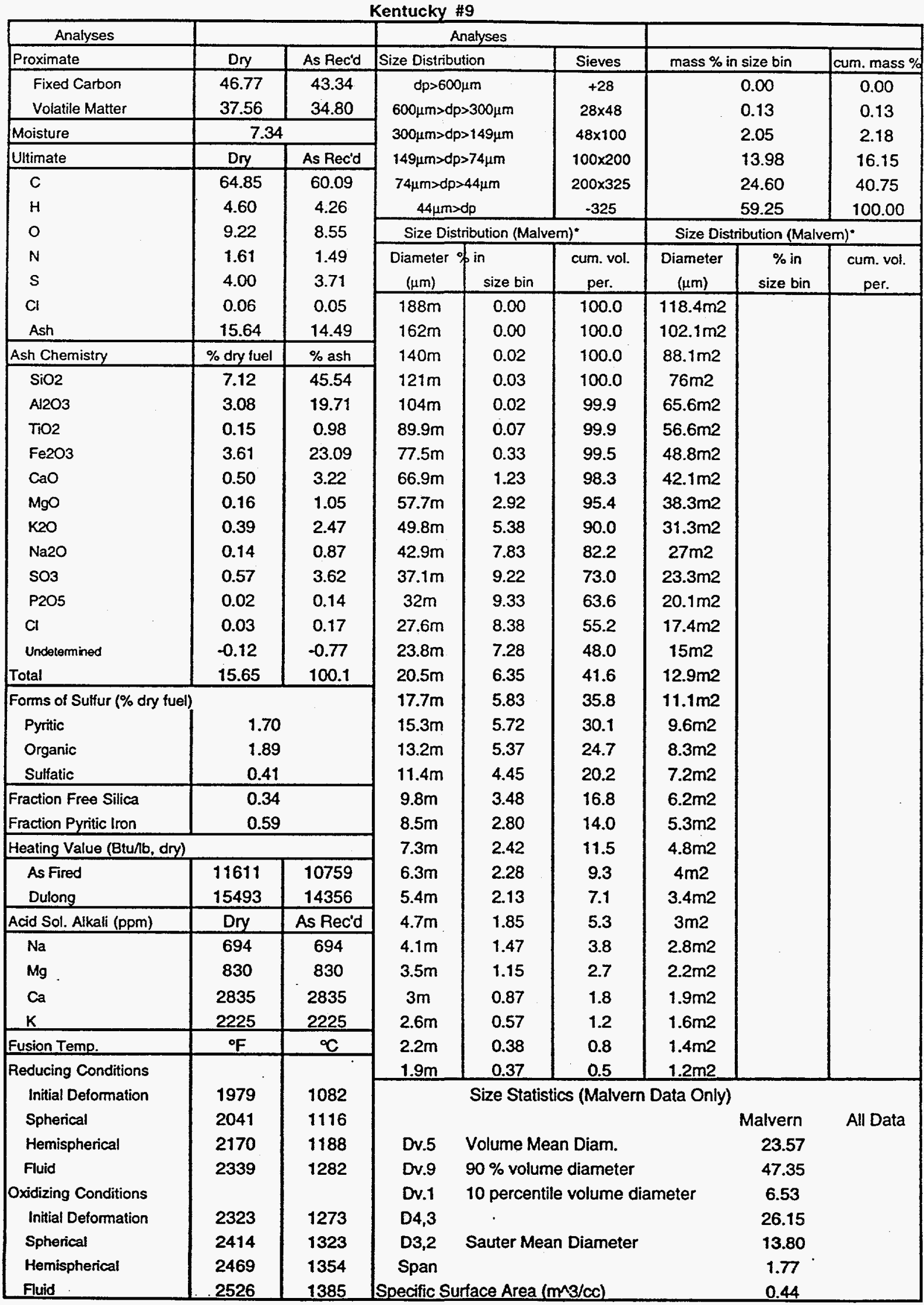

"These Malvern data are for the - 325 mesh size fractions. 
Table A.16 Summary of Properties of the Hanna Basin Coal.

\begin{tabular}{|c|c|c|c|c|c|c|c|c|}
\hline Analyses & \multicolumn{5}{|c|}{ Analyses } & \multirow{2}{*}{\multicolumn{2}{|c|}{ mass $\%$ in size bin }} & \multirow[b]{2}{*}{ cum. mass $\%$} \\
\hline Proximate & Dry & As Rec'd & \multicolumn{2}{|c|}{ Size Distribution } & Sieves & & & \\
\hline Fixed Carbon & 50.36 & 45.35 & \multirow{3}{*}{\multicolumn{2}{|c|}{$\begin{array}{c}d p>600 \mu m \\
600 \mu m>-d p>300 \mu m \\
300 \mu m>d p>149 \mu m\end{array}$}} & +28 & \multicolumn{2}{|c|}{0.00} & 0.00 \\
\hline Volatile Matter & 39.49 & 35.55 & & & $28 \times 48$ & & 0.00 & 0.00 \\
\hline Moisture & \multicolumn{2}{|c|}{9.96} & & & $48 \times 100$ & & 6.30 & 6.30 \\
\hline Ultimate & Dry & As Rec'd & \multicolumn{2}{|c|}{$149 \mu m>d p>74 \mu m$} & $100 \times 200$ & & 25.40 & 31.70 \\
\hline $\mathrm{C}$ & 67.12 & 60.44 & \multicolumn{2}{|c|}{$74 \mu \mathrm{m}>d p>44 \mu \mathrm{m}$} & $200 \times 325$ & & 24.60 & 56.30 \\
\hline$H$ & 4.79 & 4.31 & \multicolumn{2}{|c|}{$44 \mu m>d p$} & -325 & & 43.70 & 100.00 \\
\hline 0 & 16.02 & 14.42 & \multicolumn{3}{|c|}{ Size Distribution (Malvem) ${ }^{*}$} & \multicolumn{3}{|c|}{ Size Distribution (Malvem) } \\
\hline$N$ & 1.26 & 1.13 & Diameter : & in & cum. vol. & Diameter & $\%$ in & curn. vol. \\
\hline$s$ & 0.65 & 0.58 & $(\mu \mathrm{m})$ & size bin & per. & $(\mu \mathrm{m})$ & size bin & per. \\
\hline $\mathrm{Cl}$ & 0.03 & 0.02 & $188 \mathrm{~m}$ & 0.00 & 100.0 & $118.4 \mathrm{~m} 2$ & & \\
\hline Ash & 9.99 & 9.00 & $162 \mathrm{~m}$ & 0.05 & 100.0 & $102.1 \mathrm{~m} 2$ & & \\
\hline Ash Chemistry & $\%$ dry fuel & $\%$ ash & $140 \mathrm{~m}$ & 0.10 & 99.9 & $88.1 \mathrm{~m} 2$ & & \\
\hline $\mathrm{SiO} 2$ & 3.63 & 36.34 & $121 \mathrm{~m}$ & 0.15 & 99.7 & $76 \mathrm{~m} 2$ & & \\
\hline $\mathrm{Al} 2 \mathrm{O} 3$ & 1.49 & 14.94 & $104 \mathrm{~m}$ & 0.20 & 99.5 & $65.6 \mathrm{~m} 2$ & & \\
\hline $\mathrm{TIO} 2$ & 0.07 & 0.75 & $89.9 \mathrm{~m}$ & 0.15 & 99.4 & $56.6 \mathrm{~m} 2$ & & \\
\hline $\mathrm{Fe} 2 \mathrm{O} 3$ & 0.82 & 8.21 & $77.5 \mathrm{~m}$ & 0.45 & 98.9 & $48.8 \mathrm{~m} 2$ & & \\
\hline $\mathrm{CaO}$ & 2.20 & 22.01 & $66.9 \mathrm{~m}$ & 1.90 & 97.0 & $42.1 \mathrm{~m} 2$ & & \\
\hline $\mathrm{MgO}$ & 0.33 & 3.26 & $57.7 \mathrm{~m}$ & 4.25 & 92.8 & $38.3 \mathrm{~m} 2$ & & \\
\hline $\mathrm{K} 20$ & 0.08 & 0.82 & $49.8 m$ & 7.45 & 85.3 & $31.3 \mathrm{~m} 2$ & & \\
\hline $\mathrm{Na} 2 \mathrm{O}$ & 0.09 & 0.87 & $42.9 \mathrm{~m}$ & 10.35 & 75.0 & $27 \mathrm{~m} 2$ & & \\
\hline $\mathrm{SO} 3$ & 1.07 & 10.76 & $37.1 \mathrm{~m}$ & 10.80 & 64.2 & $23.3 \mathrm{~m} 2$ & & \\
\hline P2O5 & 0.07 & 0.66 & $32 m$ & 10.05 & 54.1 & $20.1 \mathrm{~m} 2$ & & \\
\hline $\mathrm{Cl}$ & & & $27.6 \mathrm{~m}$ & 8.30 & 45.8 & $17.4 \mathrm{~m} 2$ & & \\
\hline Undetermined & 0.10 & 1.01 & $23.8 \mathrm{~m}$ & 6.30 & 39.5 & $15 \mathrm{~m} 2$ & & \\
\hline Total & 9.95 & 99.6 & $20.5 \mathrm{~m}$ & 5.40 & 34.1 & $12.9 \mathrm{~m} 2$ & & \\
\hline \multicolumn{3}{|c|}{ Forms of Sulfur ( $\%$ dry fuel) } & $17.7 \mathrm{~m}$ & 5.15 & 29.0 & $11.1 \mathrm{~m} 2$ & & \\
\hline Pyritic & \multicolumn{2}{|c|}{0.19} & $15.3 \mathrm{~m}$ & 5.05 & 23.9 & $9.6 \mathrm{~m} 2$ & & \\
\hline Organic & \multicolumn{2}{|c|}{0.43} & $13.2 \mathrm{~m}$ & 4.60 & 19.3 & $8.3 \mathrm{~m} 2$ & & \\
\hline Sultatic & \multicolumn{2}{|c|}{0.03} & $11.4 \mathrm{~m}$ & 3.45 & 15.9 & $7.2 \mathrm{~m} 2$ & & \\
\hline Fraction Free Silica & \multicolumn{2}{|c|}{0.38} & $9.8 \mathrm{~m}$ & 2.70 & 13.2 & $6.2 \mathrm{~m} 2$ & & \\
\hline Fraction Pyritic Iron & \multicolumn{2}{|c|}{0.19} & $8.5 \mathrm{~m}$ & 2.15 & 11.0 & $5.3 \mathrm{~m} 2$ & & \\
\hline \multicolumn{3}{|c|}{ Heating Value (Btu/b, dry) } & $7.3 m$ & 1.90 & 9.1 & $4.8 \mathrm{~m} 2$ & & \\
\hline As Fired & 11921 & 10734 & $6.3 \mathrm{~m}$ & 1.70 & 7.4 & $4 m 2$ & & \\
\hline Dulong & 11517 & 10370 & $5.4 \mathrm{~m}$ & 1.60 & 5.8 & $3.4 \mathrm{~m} 2$ & & \\
\hline Acid Sol. Alkali (ppm) & Dry & As Rec'd & $4.7 \mathrm{~m}$ & 1.40 & 4.4 & $3 m 2$ & & \\
\hline $\mathrm{Na}$ & & & $4.1 \mathrm{~m}$ & 1.20 & 3.2 & $2.8 \mathrm{~m} 2$ & & \\
\hline Mg & & & $3.5 \mathrm{~m}$ & 0.95 & 2.3 & $2.2 \mathrm{~m} 2$ & & \\
\hline $\mathrm{Ca}$ & & & $3 m$ & 0.75 & 1.5 & $1.9 \mathrm{~m} 2$ & & \\
\hline $\mathbf{K}$ & & & $2.6 \mathrm{~m}$ & 0.50 & 1.0 & $1.6 \mathrm{~m} 2$ & & \\
\hline Fusion Temp. & F & ${ }^{\circ} \mathrm{C}$ & $2.2 \mathrm{~m}$ & 0.35 & 0.7 & $1.4 \mathrm{~m} 2$ & & \\
\hline Reducing Conditions & & & $1.9 \mathrm{~m}$ & 0.25 & 0.4 & $1.2 \mathrm{~m} 2$ & & \\
\hline Initial Deformation & 2186 & 1196 & & Size Stati & s (Malverr & Data Only) & & \\
\hline Spherical & 2245 & 1229 & & & & & Malvern & All Data \\
\hline Hemispherical & 2276 & 1246 & Dv.5 & Volume $\mathrm{M}$ & Diam. & & 29.70 & \\
\hline Fluid & 2338 & 1281 & Dv.9 & $90 \%$ volu & diameter & - & 54.20 & \\
\hline Oxidizing Conditions & & & Dv.1 & 10 percen & volume $\mathrm{d}$ & meter & 7.85 & \\
\hline Initial Deformation & 2275 & 1246 & D4,3 & & & & 31.15 & \\
\hline Spherical & 2316 & 1269 & D3,2 & Sauter Me & Diameter & & 16.15 & \\
\hline Hemispherical & 2349 & 1287 & Span & $\bullet$ & & & 1.55 & \\
\hline Fluid & 2452 & 1344 & Specific Su & face Area & $3 / c c)$ & & 0.38 & \\
\hline
\end{tabular}

These Malvern data are for the -325 mesh size fractions. 
Table A.17 Summary of Properties of the Illinois \#6 (1) Coal.

Illinois \#6 (1)

\begin{tabular}{|c|c|c|c|c|c|c|c|c|}
\hline \multirow{2}{*}{\begin{tabular}{|l} 
Analyses \\
Proximate \\
\end{tabular}} & & & \multicolumn{3}{|c|}{ Analyses } & \multirow{2}{*}{\multicolumn{2}{|c|}{ mass $\%$ in size bin }} & \multirow[b]{2}{*}{ cum. mass $\%$} \\
\hline & Dry & As Rec'd & \multicolumn{2}{|c|}{ Size Distribution } & Sieves & & & \\
\hline Fixed Carbon & 48.90 & 43.69 & \multirow{3}{*}{\multicolumn{2}{|c|}{$\begin{array}{c}d p>600 \mu m \\
600 \mu m>d p>300 \mu m \\
300 \mu m>d p>149 \mu m\end{array}$}} & +28 & & 0.00 & 0.00 \\
\hline Volatile Matter & 40.83 & 36.48 & & & $28 \times 48$ & & 0.05 & 0.05 \\
\hline Moisture & \multicolumn{2}{|l|}{10.65} & & & $48 \times 100$ & & 1.75 & 1.80 \\
\hline Ultimate & Dry & As Rec'd & \multicolumn{2}{|c|}{$149 \mu m>d p>74 \mu m$} & $100 \times 200$ & & 14.50 & 16.30 \\
\hline $\mathrm{C}$ & 68.50 & 61.20 & \multicolumn{2}{|c|}{$74 \mu m>d p>44 \mu m$} & $200 \times 325$ & & 27.30 & 43.60 \\
\hline$H$ & 5.04 & 4.50 & \multicolumn{2}{|c|}{$44 \mu m>d p$} & -325 & & 57.65 & 101.25 \\
\hline 0 & 10.40 & 9.29 & \multicolumn{3}{|c|}{ Size Distribution (Malvem) $^{\circ}$} & \multicolumn{3}{|c|}{ Size Distribution (Malvern) } \\
\hline$N$ & 1.44 & 1.29 & \multirow{5}{*}{$\begin{array}{c}\begin{array}{c}\text { Diameter } \\
(\mu \mathrm{m})\end{array} \\
188 \mathrm{~m} \\
162 \mathrm{~m} \\
140 \mathrm{~m}\end{array}$} & \multirow{2}{*}{ sin } & cum. vol. & Diameter & $\%$ in & cum. vol. \\
\hline$s$ & 4.33 & 3.87 & & & per. & $(\mu \mathrm{m})$ & size bin & per. \\
\hline $\mathrm{Cl}$ & 0.10 & 0.09 & & 0.00 & 100.0 & $118.4 \mathrm{~m} 2$ & 0.05 & 100.0 \\
\hline Ash & 10.24 & 9.15 & & 0.03 & 100.0 & $102.1 \mathrm{~m} 2$ & 0.15 & 99.9 \\
\hline Ash Chemistry & $\%$ dry fuel & $\%$ ash & & 0.08 & 99.9 & $88.1 \mathrm{~m} 2$ & 0.15 & 99.9 \\
\hline $\mathrm{SiO} 2$ & 4.75 & 46.35 & $121 \mathrm{~m}$ & 0.10 & 99.8 & $76 \mathrm{~m} 2$ & 0.10 & 99.9 \\
\hline $\mathrm{Al}_{2} \mathrm{O}_{3}$ & 1.71 & 16.74 & $104 m$ & 0.10 & 99.7 & $65.6 \mathrm{~m} 2$ & 1.65 & 98.4 \\
\hline T1O2 & 0.09 & 0.88 & $89.9 m$ & 0.10 & 99.6 & $56.6 \mathrm{~m} 2$ & 5.40 & 94.6 \\
\hline $\mathrm{Fe} 2 \mathrm{O} 3$ & 2.10 & 20.49 & $77.5 \mathrm{~m}$ & 0.45 & 99.2 & $48.8 \mathrm{~m} 2$ & 9.55 & 90.5 \\
\hline $\mathrm{CaO}$ & 0.53 & 5.15 & $66.9 \mathrm{~m}$ & 1.50 & 97.7 & $42.1 \mathrm{~m} 2$ & $10.95^{\circ}$ & 89.1 \\
\hline MgO & 0.08 & 0.78 & $57.7 \mathrm{~m}$ & 3.45 & 94.2 & $38.3 \mathrm{~m} 2$ & 9.55 & 90.5 \\
\hline $\mathrm{K} 20$ & 0.21 & 2.01 & $49.8 \mathrm{~m}$ & 6.15 & 88.1 & $31.3 \mathrm{~m} 2$ & 7.75 & 92.3 \\
\hline $\mathrm{Na2O}$ & 0.13 & 1.28 & $42.9 m$ & 8.93 & 79.1 & $27 \mathrm{~m} 2$ & 8.20 & 91.8 \\
\hline so3 & 0.51 & 4.95 & $37.1 \mathrm{~m}$ & 10.63 & 68.5 & $23.3 \mathrm{~m} 2$ & 9.55 & 90.5 \\
\hline $\mathrm{P} 2 \mathrm{O} 5$ & 0.02 & 0.16 & $32 m$ & 10.45 & 58.1 & $20.1 \mathrm{~m} 2$ & 7.55 & 92.5 \\
\hline $\mathrm{Cl}$ & 0.02 & 0.16 & $27.6 m$ & 8.88 & 49.2 & $17.4 \mathrm{~m} 2$ & 4.15 & 95.9 \\
\hline Undetemined & 0.10 & 0.96 & $23.8 \mathrm{~m}$ & 7.25 & 41.9 & $15 \mathrm{~m} 2$ & 3.65 & 96.4 \\
\hline Total & 10.23 & 99.9 & $20.5 \mathrm{~m}$ & 6.20 & 35.7 & $12.9 \mathrm{~m} 2$ & 4.90 & 95.1 \\
\hline \multicolumn{3}{|c|}{ Forms of Sulfur (\% dry fuel) } & $17.7 m$ & 6.00 & 29.7 & $11.1 \mathrm{~m} 2$ & 4.20 & 95.8 \\
\hline Pyritic & \multicolumn{2}{|l|}{1.20} & $15.3 \mathrm{~m}$ & 5.83 & 23.9 & $9.6 \mathrm{~m} 2$ & 3.00 & 97.0 \\
\hline Organic & \multicolumn{2}{|l|}{2.78} & $13.2 \mathrm{~m}$ & 5.05 & 18.9 & $8.3 \mathrm{~m} 2$ & 1.60 & 98.4 \\
\hline Sulfatic & \multicolumn{2}{|l|}{0.36} & $11.4 \mathrm{~m}$ & 3.88 & 15.0 & $7.2 \mathrm{~m} 2$ & 1.20 & 98.8 \\
\hline Fraction Free Silica & \multirow{2}{*}{\multicolumn{2}{|c|}{$\begin{array}{l}0.46 \\
0.72\end{array}$}} & $9.8 \mathrm{~m}$ & 2.80 & 12.2 & $6.2 \mathrm{~m} 2$ & 1.55 & 98.5 \\
\hline Fraction Pyritic Iron & & & $8.5 \mathrm{~m}$ & 2.20 & 10.0 & $5.3 \mathrm{~m} 2$ & 1.35 & 98.7 \\
\hline Heating Value (Btu/b, & & & $7.3 m$ & 1.93 & 8.1 & $4.8 \mathrm{~m} 2$ & 1.15 & 98.9 \\
\hline As Fired & 12182 & 10885 & $6.3 m$ & 1.85 & 6.2 & $4 m 2$ & 0.80 & 99.2 \\
\hline Dulong & 12457 & 11131 & $5.4 m$ & 1.63 & 4.6 & $3.4 \mathrm{~m} 2$ & 0.75 & 99.3 \\
\hline Acid Sol. Alkali (ppm) & Dry & As Rec'd & $4.7 m$ & 1.28 & 3.3 & $3 m 2$ & 0.70 & 99.3 \\
\hline $\mathrm{Na}$ & 2256 & 2256 & $4.1 \mathrm{~m}$ & 1.00 & 2.3 & $2.8 \mathrm{~m} 2$ & 0.10 & 99.9 \\
\hline $\mathrm{Mg}$ & 1766 & 1766 & $3.5 \mathrm{~m}$ & 0.80 & 1.5 & $2.2 \mathrm{~m} 2$ & 0.10 & 99.9 \\
\hline $\mathrm{Ca}$ & 5977 & 5977 & $3 m$ & 0.55 & 0.9 & $1.9 \mathrm{~m} 2$ & 0.00 & 100.0 \\
\hline$K$ & 2380 & 2380 & $2.6 \mathrm{~m}$ & 0.33 & 0.6 & $1.6 \mathrm{~m} 2$ & 0.00 & 100.0 \\
\hline Fusion Temp. & of & ${ }^{\circ} \mathrm{C}$ & $2.2 m$ & 0.23 & 0.4 & $1.4 \mathrm{~m} 2$ & 0.00 & 100.0 \\
\hline Reducing Conditions & & & $1.9 \mathrm{~m}$ & 0.20 & 0.2 & $1.2 \mathrm{~m} 2$ & 0.00 & 100.0 \\
\hline Initial Deformation & 1939 & 1060 & $\cdot$ & Size Stati & s (Malver & Data Only) & & \\
\hline Spherical & 1995 & 1090 & & & & & Malvern & All Data \\
\hline Hemispherical & 2110 & 1154 & Dv.5 & Volume $M$ & Diam. & & 25.63 & \\
\hline Fluid & 2287 & 1253 & Dv.9 & $90 \%$ volu & diameter & & 47.92 & \\
\hline Oxidizing Conditions & & & Dv.1 & 10 percen & volume d & meter & 8.17 & \\
\hline Initial Deformation & 2266 & 1241 & D4,3 & & & & 27.10 & \\
\hline Spherical & 2291 & 1255 & 03,2 & Sauter ME & Diameter & & 15.72 & \\
\hline Hemispherical & 2346 & 1285 & Span & & & & 1.57 & \\
\hline Fluid & 2491 & 1366 & Specific Su & Iface Area & $1 /(c)$ & & 0.37 & \\
\hline
\end{tabular}

These Malvem data are for the -325 mesh size fractions. 
Table A.18 Summary of Properties of the Roland Coal.

Roland

\begin{tabular}{|c|c|c|c|c|c|c|c|c|}
\hline \multirow{2}{*}{\begin{tabular}{|l} 
Analyses \\
Proximate \\
\end{tabular}} & & & \multicolumn{3}{|c|}{ Analyses } & \multirow{2}{*}{\multicolumn{2}{|c|}{ mass $\%$ in size bin }} & \multirow[b]{2}{*}{ cum. mass $\%$} \\
\hline & Dry & As Rec'd & \multicolumn{2}{|c|}{ Size Distribution } & Sieves & & & \\
\hline Fixed Carbon & 48.45 & 43.46 & \multirow{3}{*}{\multicolumn{2}{|c|}{$\begin{array}{c}d p>600 \mu m \\
600 \mu m>d p>300 \mu m \\
300 \mu m>d p>149 \mu m\end{array}$}} & +28 & & 0.00 & 0.00 \\
\hline Volatile Matter & 45.39 & 40.72 & & & $28 \times 48$ & & 0.80 & 0.80 \\
\hline Moisture & \multicolumn{2}{|c|}{10.29} & & & $48 \times 100$ & & 1.80 & 2.60 \\
\hline Ultimate & Dry & As Rec'd & \multicolumn{2}{|c|}{$149 \mu m>d p>74 \mu m$} & $100 \times 200$ & & 26.50 & 29.10 \\
\hline C & 69.94 & 62.74 & \multicolumn{2}{|c|}{$74 \mu m>d p>44 \mu m$} & $200 \times 325$ & & 28.97 & 58.07 \\
\hline$H$ & 4.76 & 4.27 & \multicolumn{2}{|c|}{$44 \mu m>d p$} & -325 & & 41.93 & 100.00 \\
\hline 0 & 17.79 & 15.96 & \multicolumn{3}{|c|}{ Size Distribution (Malvern)* } & \multicolumn{3}{|c|}{ Size Distribution (Malvern) } \\
\hline $\mathbf{N}$ & 0.91 & 0.82 & Diameter : & pin & cum. vol. & Diameter & $\%$ in & cum. vol. \\
\hline s & 0.40 & 0.36 & $(\mu \mathrm{m})$ & size bin & per. & $(\mu m)$ & size bin & per. \\
\hline $\mathrm{Cl}$ & 0.03 & 0.03 & $188 \mathrm{~m}$ & 0.00 & 100.0 & $118.4 \mathrm{~m} 2$ & & \\
\hline Ash & 6.16 & 5.53 & $162 m$ & 0.00 & 100.0 & $102.1 \mathrm{~m} 2$ & & \\
\hline Ash Chemistry & $\%$ dryfuel & $\%$ ash & $140 m$ & 0.00 & 100.0 & $88.1 \mathrm{~m} 2$ & & \\
\hline $\mathrm{SiO} 2$ & 1.87 & 30.42 & $121 \mathrm{~m}$ & 0.00 & 100.0 & $76 \mathrm{~m} 2$ & & \\
\hline $\mathrm{Al} 2 \mathrm{O} 3$ & 0.91 & 14.81 & $104 m$ & 0.00 & 100.0 & $65.6 \mathrm{~m} 2$ & & \\
\hline $\mathrm{TIO} 2$ & 0.07 & 1.12 & $89.9 m$ & 0.03 & 100.0 & $56.6 \mathrm{~m} 2$ & & \\
\hline $\mathrm{Fe} 2 \mathrm{O} 3$ & 0.44 & 7.22 & $77.5 \mathrm{~m}$ & 0.18 & 99.8 & $48.8 \mathrm{~m} 2$ & & \\
\hline $\mathrm{CaO}$ & 1.28 & 20.72 & $66.9 m$ & 1.00 & 98.8 & $42.1 \mathrm{~m} 2$ & & \\
\hline $\mathrm{MgO}$ & 0.31 & 5.08 & $57.7 \mathrm{~m}$ & 2.50 & 96.3 & $38.3 \mathrm{~m} 2$ & & \\
\hline $\mathrm{K} 20$ & 0.02 & 0.38 & $49.8 m$ & 4.75 & 91.6 & $31.3 \mathrm{~m} 2$ & & \\
\hline $\mathrm{Na} 2 \mathrm{O}$ & 0.12 & 1.95 & $42.9 m$ & 7.30 & 84.3 & $27 \mathrm{~m} 2$ & & \\
\hline SO3 & 1.00 & 16.16 & $37.1 \mathrm{~m}$ & 9.20 & 75.1 & $23.3 \mathrm{~m} 2$ & & \\
\hline P2O5 & 0.07 & 1.08 & $32 \mathrm{~m}$ & 9.20 & 65.9 & $20.1 \mathrm{~m} 2$ & & \\
\hline $\mathrm{Cl}$ & & & $27.6 \mathrm{~m}$ & 7.28 & 58.6 & $17.4 \mathrm{~m} 2$ & & \\
\hline Undetermined & 0.07 & 1.07 & $23.8 \mathrm{~m}$ & 5.60 & 53.0 & $15 \mathrm{~m} 2$ & & \\
\hline Total & 6.16 & 100.0 & $20.5 m$ & 5.05 & 47.9 & $12.9 \mathrm{~m} 2$ & & \\
\hline \multicolumn{3}{|c|}{ Forms of Sulfur (\% dry fuel) } & $17.7 \mathrm{~m}$ & 5.25 & 42.7 & $11.1 \mathrm{~m} 2$ & & \\
\hline Pyritic & \multicolumn{2}{|c|}{0.07} & $15.3 \mathrm{~m}$ & 5.48 & 37.2 & $9.6 \mathrm{~m} 2$ & & \\
\hline Organic & \multicolumn{2}{|c|}{0.27} & $13.2 \mathrm{~m}$ & 5.03 & 32.2 & $8.3 \mathrm{~m} 2$ & & \\
\hline Sulfatic & \multicolumn{2}{|c|}{0.00} & $11.4 \mathrm{~m}$ & 4.10 & 28.1 & $7.2 \mathrm{~m} 2$ & & \\
\hline Fraction Free Silica & \multicolumn{2}{|c|}{0.27} & $9.8 \mathrm{~m}$ & 3.38 & 24.7 & $6.2 \mathrm{~m} 2$ & & \\
\hline Fraction Pyritic Iron & \multicolumn{2}{|c|}{0.13} & $8.5 m$ & 3.10 & 21.6 & $5.3 \mathrm{~m} 2$ & & \\
\hline \multicolumn{3}{|c|}{ Heating Value (Btu/b, dry) } & $7.3 \mathrm{~m}$ & 3.13 & 18.5 & $4.8 \mathrm{~m} 2$ & & \\
\hline As Fired & 11877 & 10655 & $6.3 m$ & 3.18 & 15.3 & $4 \mathrm{~m} 2$ & & \\
\hline Dulong & 11762 & 10551 & $5.4 \mathrm{~m}$ & 3.08 & 12.2 & $3.4 \mathrm{~m} 2$ & & \\
\hline Acid Sol. Alkali (ppm) & Dry & As Rec'd & $4.7 \mathrm{~m}$ & 2.73 & 9.5 & $3 \mathrm{~m} 2$ & & \\
\hline $\mathrm{Na}$ & & & $4.1 \mathrm{~m}$ & 2.25 & 7.3 & $2.8 \mathrm{~m} 2$ & & \\
\hline $\mathrm{Mg}$ & & & $3.5 \mathrm{~m}$ & 1.73 & 5.5 & $2.2 \mathrm{~m} 2$ & & \\
\hline $\mathrm{Ca}$ & & & $3 m$ & 1.25 & 4.3 & $1.9 \mathrm{~m} 2$ & & \\
\hline $\mathbf{K}$ & & & $2.6 \mathrm{~m}$ & 1.03 & 3.3 & $1.6 \mathrm{~m} 2$ & & \\
\hline Fusion Temp. & ${ }^{\circ} \mathrm{F}$ & ${ }^{\circ} \mathrm{C}$ & $2.2 \mathrm{~m}$ & 0.83 & 2.4 & $1.4 \mathrm{~m} 2$ & & \\
\hline Reducing Conditions & & & $1.9 \mathrm{~m}$ & 1.23 & 1.2 & $1.2 \mathrm{~m} 2$ & & \\
\hline Initial Deformation & 2066 & 1130 & & Size Stati & s (Malver & Data Only) & & \\
\hline Spherical & 2113 & 1156 & & & & & Malvern & All Data \\
\hline Hemispherical & 2131 & 1166 & Dv.5 & Volume $M$ & Diam. & & 20.20 & \\
\hline Fluid & 2188 & 1198 & Dv.9 & $90 \%$ volu & diameter & & 44.78 & \\
\hline Oxidizing Conditions & & & Dv.1 & 10 percen & volume di & meter & 4.55 & \\
\hline Initial Deformation & 2132 & 1167 & D4,3 & & & & 22.93 & \\
\hline Spherical & 2177 & 1191 & $\mathrm{D} 3,2$ & Sauter Me & Diameter & & 10.40 & \\
\hline Hemispherical & 2202 & 1205 & Span & & & & 1.98 & \\
\hline Fluid & 2271 & 1244 & Specific Su & face Area & $3 / \infty c)$ & & 0.61 & \\
\hline
\end{tabular}

These Malvern data are for the -325 mesh size fractions. 
Table A.19 Summary of Properties of the Decker Coal.

Decker

\begin{tabular}{|c|c|c|c|c|c|c|c|c|}
\hline \multirow{2}{*}{\begin{tabular}{|l} 
Analyses \\
Proximate
\end{tabular}} & & & \multicolumn{3}{|c|}{ Analyses } & \multirow{2}{*}{\multicolumn{2}{|c|}{ mass $\%$ in size bin }} & \multirow[b]{2}{*}{ cum. mass $\%$} \\
\hline & Dry & As Rec'd & \multicolumn{2}{|c|}{ Size Distribution } & Sieves & & & \\
\hline Fixed Carbon & 51.45 & 42.46 & \multirow{3}{*}{\multicolumn{2}{|c|}{$\begin{array}{c}d p>600 \mu m \\
600 \mu m>d p>300 \mu m \\
300 \mu m>d p>149 \mu m\end{array}$}} & +28 & & 0.00 & 0.00 \\
\hline Volatile Matter & 43.45 & 35.86 & & & $28 \times 48$ & & 0.10 & 0.10 \\
\hline Moisture & \multicolumn{2}{|l|}{17.48} & & & $48 \times 100$ & & 4.00 & 4.10 \\
\hline Ultimate & Dry & As Rec'd & \multicolumn{2}{|c|}{$149 \mu \mathrm{m}>d p>74 \mu m$} & $100 \times 200$ & & 23.97 & 28.07 \\
\hline $\mathrm{c}$ & 72.04 & 59.45 & \multicolumn{2}{|c|}{$74 \mu m>d p>44 \mu m$} & $200 \times 325$ & & 25.03 & 53.10 \\
\hline$H$ & 4.97 & 4.10 & \multicolumn{2}{|c|}{$44 \mu m>d p$} & -325 & & 46.90 & 100.00 \\
\hline 0 & .16 .36 & 13.50 & \multicolumn{3}{|c|}{ Size Distribution (Malvem) ${ }^{*}$} & \multicolumn{3}{|c|}{ Size Distribution (Malvem) } \\
\hline$N$ & 1.00 & 0.82 & Diameter of & in & cum. vol. & Diameter & $\%$ in & cum. vol. \\
\hline S & 0.53 & 0.43 & $(\mu \mathrm{m})$ & size bin & per. & $(\mu \mathrm{m})$ & size bin & per. \\
\hline $\mathrm{Cl}$ & 0.02 & 0.02 & $188 \mathrm{~m}$ & 0.36 & 99.6 & $118.4 \mathrm{~m} 2$ & & \\
\hline Ash & 5.12 & 4.23 & $162 \mathrm{~m}$ & 0.95 & 98.7 & $102.1 \mathrm{~m} 2$ & & \\
\hline Ash Chemistry & $\%$ dry fuel & $\%$ ash & $140 \mathrm{~m}$ & 1.41 & 97.3 & $88.1 \mathrm{~m} 2$ & & \\
\hline $\mathrm{SiO} 2$ & 1.32 & 25.78 & $121 \mathrm{~m}$ & 1.78 & 95.5 & $76 \mathrm{~m} 2$ & & \\
\hline Al2O3 & 0.87 & 16.96 & $104 m$ & 1.89 & 93.6 & $65.6 \mathrm{~m} 2$ & & \\
\hline TIO2 & 0.06 & 1.15 & $89.9 m$ & 1.96 & 91.7 & $56.6 \mathrm{~m} 2$ & & \\
\hline $\mathrm{Fe} 2 \mathrm{O} 3$ & 0.33 & 6.42 & $77.5 \mathrm{~m}$ & 2.05 & 89.6 & $48.8 \mathrm{~m}^{2}$ & & \\
\hline $\mathrm{CaO}$ & 0.74 & 14.51 & $66.9 \mathrm{~m}$ & 2.48 & 87.1 & $42.1 \mathrm{~m} 2$ & & \\
\hline $\mathrm{MgO}$ & 0.16 & 3.14 & $57.7 \mathrm{~m}$ & 3.40 & 83.7 & $38.3 \mathrm{~m} 2$ & & \\
\hline $\mathrm{K} 2 \mathrm{O}$ & 0.02 & 0.47 & $49.8 m$ & 5.38 & 78.4 & $31.3 \mathrm{~m} 2$ & & \\
\hline $\mathrm{Na} 2 \mathrm{O}$ & 0.41 & 7.99 & $42.9 \mathrm{~m}$ & 7.54 & 70.8 & $27 m 2$ & & \\
\hline SO3 & 1.07 & 20.83 & $37.1 \mathrm{~m}$ & 9.31 & 61.5 & $23.3 \mathrm{~m} 2$ & & \\
\hline $\mathrm{P} 205$ & 0.05 & 0.93 & $32 m$ & 9.10 & 52.4 & $20.1 \mathrm{~m} 2$ & & \\
\hline $\mathrm{Cl}$ & & & $27.6 \mathrm{~m}$ & 7.10 & 45.3 & $17.4 \mathrm{~m} 2$ & & \\
\hline Undetermined & 0.09 & 1.82 & $23.8 \mathrm{~m}$ & 5.41 & 39.9 & $15 \mathrm{~m} 2$ & & \\
\hline Total & 5.12 & 100.0 & $20.5 m$ & 4.73 & 35.2 & $12.9 \mathrm{~m} 2$ & & \\
\hline \multicolumn{3}{|c|}{ Forms of Sulfur (\% dry fuel) } & $17.7 \mathrm{~m}$ & 4.95 & 30.2 & $11.1 \mathrm{~m} 2$ & & \\
\hline Pyritic & \multicolumn{2}{|c|}{0.16} & $15.3 m$ & 5.19 & 25.0 & $9.6 \mathrm{~m} 2$ & & \\
\hline Organic & \multicolumn{2}{|c|}{0.33} & $13.2 \mathrm{~m}$ & 4.65 & 20.4 & $8.3 \mathrm{~m} 2$ & & \\
\hline Sulfatic & \multicolumn{2}{|c|}{0.04} & $11.4 \mathrm{~m}$ & 3.71 & 16.7 & $7.2 \mathrm{~m} 2$ & & \\
\hline Fraction Free Silica & \multicolumn{2}{|c|}{0.02} & $9.8 \mathrm{~m}$ & 2.75 & 13.9 & $6.2 \mathrm{~m} 2$ & & \\
\hline Fraction Pyritic Iron & \multicolumn{2}{|c|}{0.61} & $8.5 m$ & 2.33 & 11.6 & $5.3 \mathrm{~m} 2$ & & \\
\hline \multicolumn{3}{|c|}{ Heating Value (Btu/bo, dry) } & $7.3 \mathrm{~m}$ & 2.28 & 9.3 & $4.8 \mathrm{~m} 2$ & & \\
\hline As Fired & 12424 & 10253 & $6.3 \mathrm{~m}$ & 2.23 & 7.1 & $4 \mathrm{~m} 2$ & & \\
\hline Dulong & 12315 & 10162 & $5.4 m$ & 2.01 & 5.1 & $3.4 \mathrm{~m} 2$ & & \\
\hline Acid Sol. Alkali (ppm) & Dry & As Rec'd & $4.7 \mathrm{~m}$ & 1.53 & 3.6 & $3 m 2$ & & $\cdot$ \\
\hline $\mathrm{Na}$ & & & $4.1 \mathrm{~m}$ & 1.01 & 2.5 & $2.8 \mathrm{~m} 2$ & & \\
\hline $\mathrm{Mg}$ & & & $3.5 \mathrm{~m}$ & 0.79 & 1.8 & $2.2 \mathrm{~m} 2$ & & \\
\hline $\mathrm{Ca}$ & & & $3 m$ & 0.54 & 1.2 & $1.9 \mathrm{~m} 2$ & & \\
\hline $\mathbf{K}$ & & & $2.6 \mathrm{~m}$ & 0.31 & 0.9 & $1.6 \mathrm{~m} 2$ & & \\
\hline Fusion Temp. & ${ }^{\circ} \mathrm{F}$ & ${ }^{\circ} \mathrm{C}$ & $2.2 m$ & 0.31 & 0.6 & $1.4 \mathrm{~m} 2$ & & \\
\hline Reducing Conditions & & & $1.9 \mathrm{~m}$ & 0.49 & 0.1 & $1.2 \mathrm{~m} 2$ & & \\
\hline Initial Deformation & 2056 & 1124 & & Size Stat & s (Malven & Data Only) & & \\
\hline Spherical & 2143 & 1173 & & & & & Malvern & All Data \\
\hline Hemispherical & 2161 & 1183 & Dv.5 & Volume $\mathrm{N}$ & Diam. & & 31.06 & \\
\hline Fluid & 2194 & 1201 & Dv.9 & $90 \%$ volu & diameter & & 64.68 & \\
\hline Oxidizing Conditions & & & Dv.1 & 10 percen & volume $\mathrm{d}$ & meter & 7.63 & \\
\hline Initial Deformation & 2333 & 1278 & D4,3 & & & & 34.15 & \\
\hline Spherical & 2457 & 1347 & $\mathrm{D} 3,2$ & Sauter M & Diameter & & 15.80 & \\
\hline Hernispherical & 2472 & 1356 & Span & & & • & 1.76 & \\
\hline Fluid & 2495 & 1368 & Specific Sur & face Area & $3 /(c)$ & & 0.40 & \\
\hline
\end{tabular}

These Malvern data are for the -325 mesh size fractions. 
Table A.20 Summary of Properties of the Black Thunder Coal.

Black Thunder

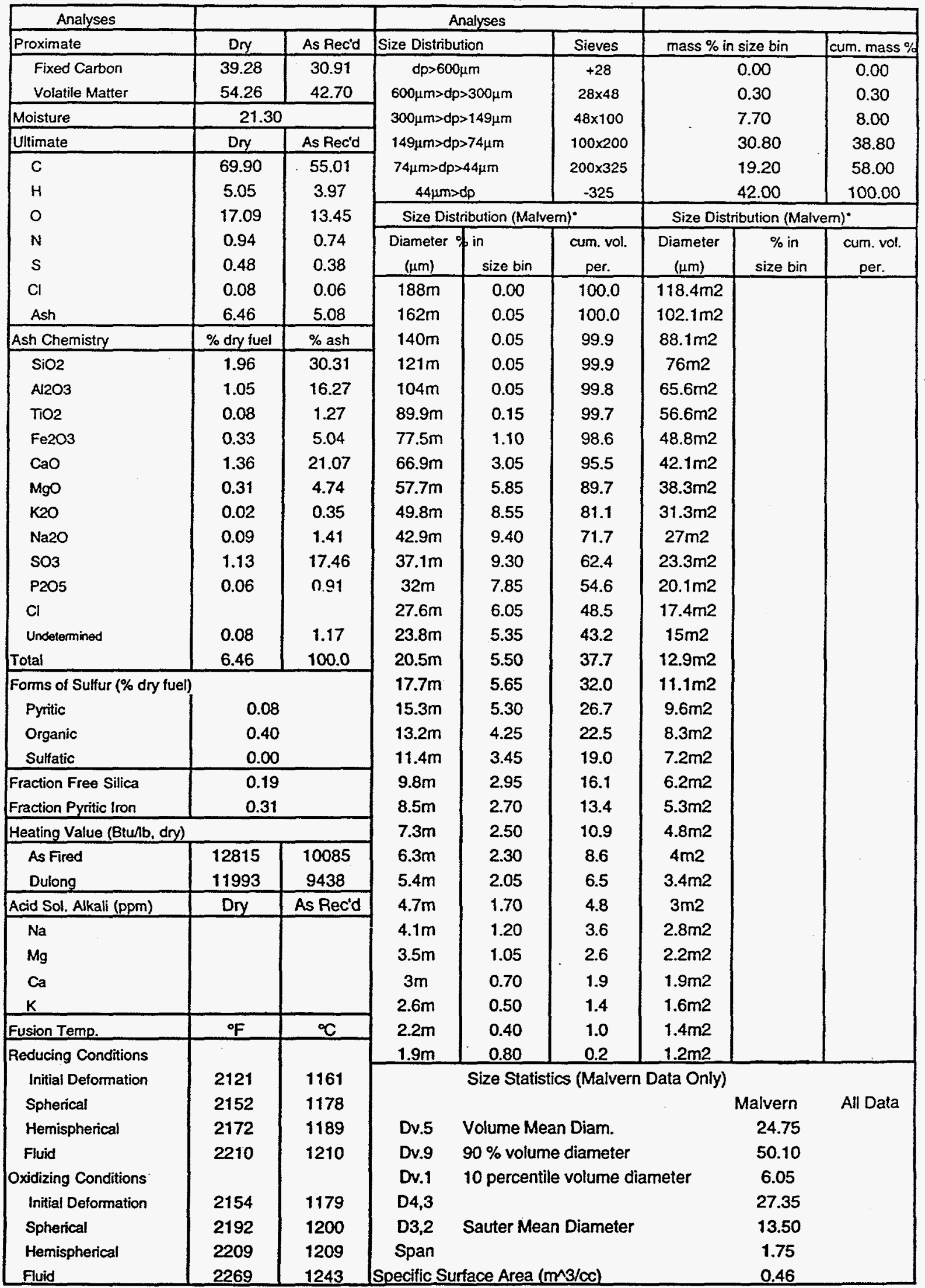

These Malvem data are for the -325 mesh size fractions. 
Table A.21 Summary of Properties of the Belle Ayr Coal.

Belle Ayr

\begin{tabular}{|c|c|c|c|c|c|c|c|c|}
\hline Analyses & & & \multicolumn{3}{|c|}{ Analyses } & \multirow{2}{*}{\multicolumn{2}{|c|}{ mass $\%$ in size bin }} & \\
\hline Proximate & Dry & As Rec'd & Size Distrit & tion & Sieves & & & cum. mass $\%$ \\
\hline Fixed Carbon & 45.78 & 34.49 & \multirow{3}{*}{\multicolumn{2}{|c|}{$\begin{array}{c}d p>600 \mu m \\
600 \mu m>d p>300 \mu m \\
300 \mu m>d p>149 \mu m\end{array}$}} & +28 & \multicolumn{2}{|r|}{0.00} & 0.00 \\
\hline Volatile Matter & 48.19 & 36.31 & & & $28 \times 48$ & & 0.50 & 0.50 \\
\hline Moisture & \multicolumn{2}{|c|}{24.65} & & & $48 \times 100$ & & 9.25 & 9.75 \\
\hline Ultimate & Dry & As Rec'd & \multicolumn{2}{|c|}{$149 \mu \mathrm{m}>d p>74 \mu \mathrm{m}$} & $100 \times 200$ & & 24.65 & 34.40 \\
\hline c & 70.27 & 52.94 & \multicolumn{2}{|c|}{$74 \mu m>d p>44 \mu m$} & $200 \times 325$ & & 17.15 & 51.55 \\
\hline$H$ & 5.05 & 3.80 & \multicolumn{2}{|c|}{$44 \mu m>d p$} & -325 & & 48.45 & 100.00 \\
\hline 0 & 17.27 & 13.01 & \multicolumn{3}{|c|}{ Size Distribution (Malvem) } & \multicolumn{3}{|c|}{ Size Distribution (Malvem) } \\
\hline$N$ & 0.90 & 0.68 & \multicolumn{2}{|c|}{ Diameter of in } & cum. vol. & \multirow{2}{*}{$\begin{array}{c}\text { Diameter } \\
(\mu \mathrm{m})\end{array}$} & \multirow{2}{*}{$\begin{array}{c}\% \text { in } \\
\text { size bin } \\
\end{array}$} & \multirow{2}{*}{$\begin{array}{c}\text { cum. vol. } \\
\text { per. }\end{array}$} \\
\hline$S$ & 0.44 & 0.33 & $(\mu \mathrm{m})$ & size bin & per. & & & \\
\hline $\mathrm{Cl}$ & 0.05 & 0.04 & $188 m$ & 0.00 & 100.0 & $118.4 \mathrm{~m} 2$ & & \\
\hline Ash & 6.04 & 4.55 & $162 \mathrm{~m}$ & 0.03 & 100.0 & $102.1 \mathrm{~m} 2$ & & \\
\hline Ash Chemistry & $\%$ dry fuel & $\%$ ash & $140 \mathrm{~m}$ & 0.08 & 99.9 & $88.1 \mathrm{~m} 2$ & & \\
\hline $\mathrm{SiO} 2$ & 1.74 & 28.81 & $121 \mathrm{~m}$ & 0.05 & 99.9 & $76 \mathrm{~m} 2$ & & \\
\hline $\mathrm{A} 203$ & 0.85 & 14.13 & $104 m$ & 0.03 & 99.8 & $65.6 \mathrm{~m} 2$ & & \\
\hline T1O2 & 0.08 & 1.40 & $89.9 m$ & 0.23 & 99.6 & $56.6 \mathrm{~m} 2$ & & \\
\hline $\mathrm{Fe} 2 \mathrm{O} 3$ & 0.31 & 5.08 & $77.5 \mathrm{~m}$ & 1.10 & 98.5 & $48.8 \mathrm{~m} 2$ & & \\
\hline $\mathrm{CaO}$ & 1.43 & 23.68 & $66.9 m$ & 2.70 & 95.8 & $42.1 \mathrm{~m} 2$ & & \\
\hline $\mathrm{MgO}$ & 0.25 & 4.10 & $57.7 \mathrm{~m}$ & 4.95 & 90.9 & $38.3 \mathrm{~m} 2$ & & \\
\hline $\mathrm{K} 2 \mathrm{O}$ & 0.01 & 0.23 & $49.8 m$ & 7.10 & 83.8 & $31.3 \mathrm{~m} 2$ & & \\
\hline $\mathrm{Na} 2 \mathrm{O}$ & 0.08 & 1.31 & $42.9 \mathrm{~m}$ & 7.85 & 75.9 & $27 \mathrm{~m} 2$ & & \\
\hline $\mathrm{SO3}$ & 1.13 & 18.78 & $37.1 \mathrm{~m}$ & 7.90 & 68.0 & $23.3 \mathrm{~m} 2$ & & \\
\hline $\mathrm{P} 2 \mathrm{O} 5$ & 0.06 & 1.04 & $32 m$ & 7.03 & 61.0 & $20.1 \mathrm{~m} 2$ & & \\
\hline $\mathrm{Cl}$ & & & $27.6 \mathrm{~m}$ & 5.90 & 55.1 & $17.4 \mathrm{~m} 2$ & & \\
\hline Undetermined & 0.09 & 1.43 & $23.8 \mathrm{~m}$ & 5.63 & 49.5 & $15 \mathrm{~m} 2$ & & \\
\hline Total & 6.04 & 100.0 & $20.5 m$ & 5.83 & 43.6 & $12.9 \mathrm{~m} 2$ & & \\
\hline \multicolumn{3}{|c|}{ Forms of Sulfur ( $\%$ dry fuel) } & $17.7 \mathrm{~m}$ & 5.88 & 37.8 & $11.1 \mathrm{~m} 2$ & & \\
\hline Pyritic & \multicolumn{2}{|c|}{0.07} & $15.3 m$ & 5.60 & 32.2 & $9.6 \mathrm{~m} 2$ & & \\
\hline Organic & \multicolumn{2}{|c|}{0.37} & $13.2 \mathrm{~m}$ & 4.65 & 27.5 & $8.3 \mathrm{~m} 2$ & & \\
\hline Suffatic & \multicolumn{2}{|c|}{0.00} & $11.4 \mathrm{~m}$ & 4.08 & 23.4 & $7.2 \mathrm{~m} 2$ & & \\
\hline Fraction Free Silica & \multicolumn{2}{|c|}{0.26} & $9.8 \mathrm{~m}$ & 3.63 & 19.8 & $6.2 \mathrm{~m} 2$ & & \\
\hline Fraction Pyritic Iron & 0.28 & & $8.5 \mathrm{~m}$ & 3.33 & 16.5 & $5.3 \mathrm{~m} 2$ & & \\
\hline Heating Value (Btunb, & & & $7.3 m$ & 3.03 & 13.5 & $4.8 \mathrm{~m} 2$ & & \\
\hline As Fired & 12781 & 9630 & $6.3 m$ & 2.78 & 10.7 & $4 \mathrm{~m} 2$ & & \\
\hline Dulong & 12027 & 9063 & $5.4 \mathrm{~m}$ & 2.43 & 8.3 & $3.4 \mathrm{~m} 2$ & & \\
\hline Acid Sol. Alkali (ppm) & Dry & As Rec'd & $4.7 \mathrm{~m}$ & 2.08 & 6.2 & $3 m 2$ & & \\
\hline $\mathrm{Na}$ & & & $4.1 \mathrm{~m}$ & 1.78 & 4.4 & $2.8 \mathrm{~m} 2$ & & \\
\hline $\mathrm{Mg}$ & & & $3.5 \mathrm{~m}$ & 1.23 & 3.2 & $2.2 \mathrm{~m} 2$ & & \\
\hline $\mathrm{Ca}$ & & & $3 m$ & 0.88 & 2.3 & $1.9 \mathrm{~m} 2$ & & \\
\hline $\mathrm{K}$ & & & $2.6 \mathrm{~m}$ & 0.78 & 1.5 & $1.6 \mathrm{~m} 2$ & & \\
\hline Fusion Temo. & ${ }^{\circ} \mathrm{F}$ & ${ }^{\circ} \mathrm{C}$ & $2.2 \mathrm{~m}$ & 0.50 & 1.0 & $1.4 \mathrm{~m} 2$ & & \\
\hline Reducing Conditions & & & $1.9 \mathrm{~m}$ & 1.13 & -0.1 & $1.2 \mathrm{~m} 2$ & & \\
\hline Initial Deformation & 1075 & 579 & & Size Stati & $s$ (Malver & Data Only) & & \\
\hline Spherical & 1098 & 592 & & & & & Malvern & All Data \\
\hline Hemispherical & 1107 & 597 & Dv.5 & Volume $M$ & Diam. & & 20.65 & \\
\hline Fluid & 1125 & 607 & Dv.9 & $90 \%$ volu & diameter & & 48.88 & \\
\hline Oxidizing Conditions & & & Dv.1 & 10 percen & volume $\mathrm{d}$ & meter & 5.20 & \\
\hline Initial Deformation & 1070 & 577 & D4,3 & & & & 25.13 & \\
\hline Spherical & 1098 & 592 & D3,2 & Sauter M & Diameter & & 11.65 & \\
\hline Hemispherical & 1109 & 598 & Span & & & & 2.10 & \\
\hline Fluid & 1126 & 608 & Specific S & face Area & $3 /(c)$ & & 0.53 & \\
\hline
\end{tabular}

These Malvem data are for the -325 mesh size fractions. 
Table A.22 Summary of Properties of the Wyodak Coal.

Wyodak

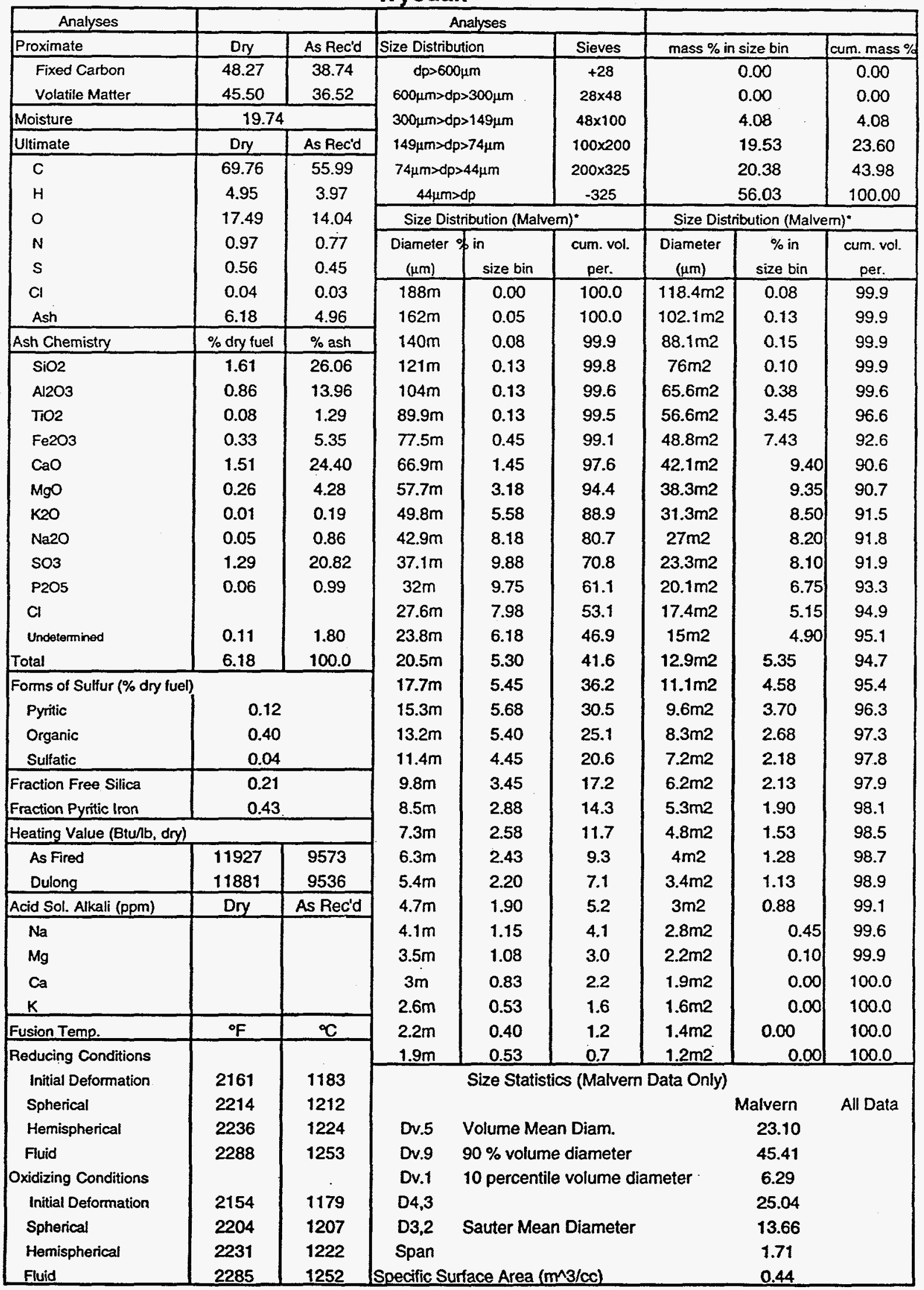

"These Malvern data are for the -325 mesh size fractions. 
Table A.23 Summary of Properties of the Antelope Coal.

Antelope

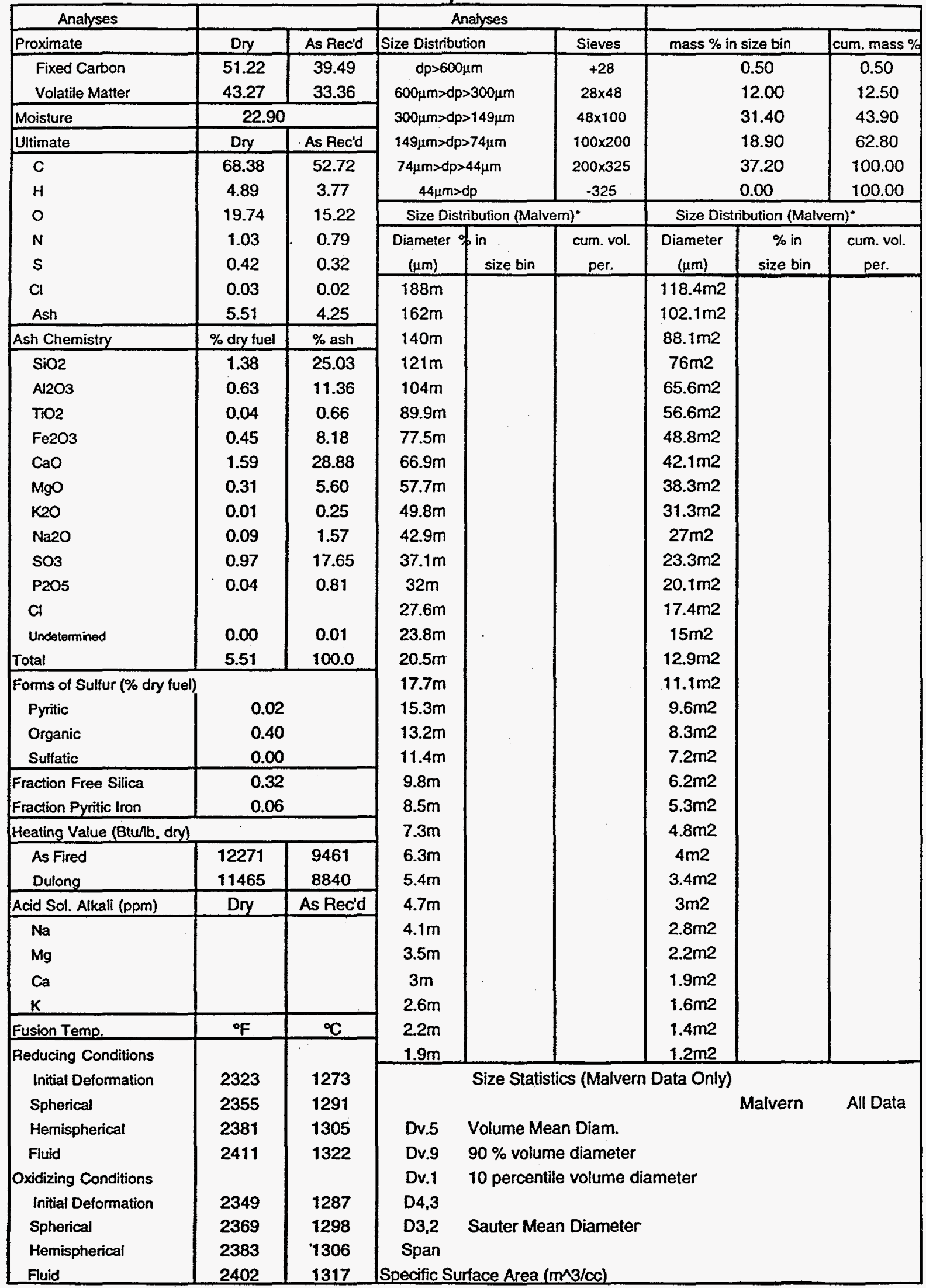

"These Malvem data are for the -325 mesh size fractions. 
Table A.24 Summary of Properties of the Eagle Butte Coal.

Eagle Butte

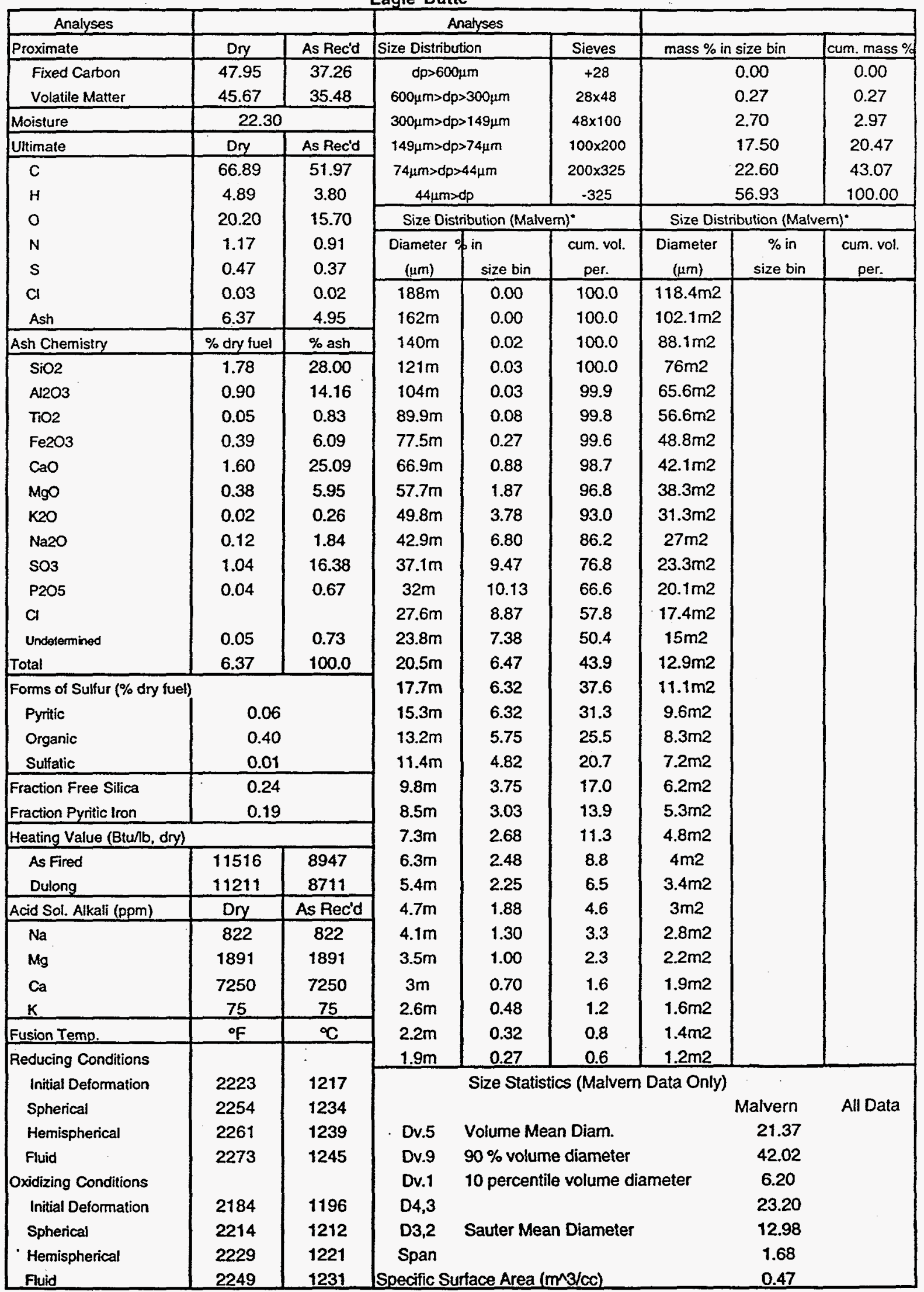

These Malvern data are for the -325 mesh size fractions. 
Table A.25 Summary of Properties of the Beulah Lignite.

Beulah

\begin{tabular}{|c|c|c|c|c|c|c|c|c|}
\hline \multirow{2}{*}{\begin{tabular}{|l}
\multicolumn{1}{c}{ Analyses } \\
Proximate \\
\end{tabular}} & & & \multicolumn{3}{|c|}{ Analyses } & \multirow{2}{*}{\multicolumn{2}{|c|}{ mass \% in size bin }} & \multirow[b]{2}{*}{ cum. mass $\%$} \\
\hline & Dry & As Rec'd & Size Distribu & tion & Sieves & & & \\
\hline Fixed Carbon & 43.44 & 32.96 & \multirow{6}{*}{\multicolumn{2}{|c|}{$\begin{array}{c}\mathrm{dp}>600 \mu \mathrm{m} \\
600 \mu \mathrm{m}>d p>300 \mu \mathrm{m} \\
300 \mu \mathrm{m}>d p>149 \mu \mathrm{m} \\
149 \mu \mathrm{m}>d p>74 \mu \mathrm{m} \\
74 \mu \mathrm{m}>d p>44 \mu \mathrm{m} \\
44 \mu m>d p \\
\end{array}$}} & +28 & & 0.06 & 0.06 \\
\hline Volatile Matter & 42.95 & 32.59 & & & $28 \times 48$ & & 2.88 & 2.94 \\
\hline Moisture & \multicolumn{2}{|c|}{24.13} & & & $48 \times 100$ & & 12.81 & 15.75 \\
\hline Uitimate & Dry & As Rec'd & & & $100 \times 200$ & & 22.60 & 38.35 \\
\hline C & 60.97 & 46.26 & & & $200 \times 325$ & & 17.20 & 55.55 \\
\hline$H$ & 4.07 & 3.09 & & & -325 & & 45.29 & 100.84 \\
\hline O & 18.50 & 14.04 & \multicolumn{3}{|c|}{ Size Distribution (Malvem) ${ }^{\bullet}$} & \multicolumn{3}{|c|}{ Size Distribution (Malvem) } \\
\hline$N$ & 1.02 & 0.77 & Diameter & in. & cum. vol. & Diameter & $\%$ in & cum. vol. \\
\hline s & 1.81 & 1.38 & $(\mu m)$ & size bin & per. & $(\mu \mathrm{m})$ & size bin & per. \\
\hline $\mathrm{Cl}$ & 0.04 & 0.03 & $188 \mathrm{~m}$ & 0.18 & 99.8 & $118.4 \mathrm{~m} 2$ & 0.08 & 99.9 \\
\hline Ash & 13.69 & 10.39 & $162 m$ & 0.49 & 99.3 & $102.1 \mathrm{~m} 2$ & 0.14 & 99.9 \\
\hline Ash Chemistry & $\%$ dry fuel & $\%$ ash & $140 \mathrm{~m}$ & 0.72 & 98.6 & $88.1 \mathrm{~m} 2$ & 0.14 & 99.9 \\
\hline $\mathrm{SiO} 2$ & 2.87 & 20.93 & $121 \mathrm{~m}$ & 0.92 & 97.7 & $76 \mathrm{~m} 2$ & 0.10 & 99.9 \\
\hline $\mathrm{Al} 2 \mathrm{O} 3$ & 1.89 & 13.78 & $104 m$ & 0.98 & 96.7 & $65.6 \mathrm{~m} 2$ & 0.00 & 100.0 \\
\hline TrO2 & 0.06 & 0.41 & $89.9 \mathrm{~m}$ & 1.20 & 95.5 & $56.6 \mathrm{~m} 2$ & 1.62 & 98.4 \\
\hline $\mathrm{Fe} 2 \mathrm{O} 3$ & 1.65 & 12.08 & $77.5 \mathrm{~m}$ & 1.53 & 94.0 & $48.8 \mathrm{~m} 2$ & 4.78 & 95.2 \\
\hline $\mathrm{CaO}$ & 2.21 & 16.13 & $66.9 m$ & 1.92 & 92.1 & $42.1 \mathrm{~m} 2$ & 6.62 & 93.4 \\
\hline $\mathrm{MgO}$ & 0.60 & 4.40 & $57.7 m$ & 2.69 & 89.4 & $38.3 \mathrm{~m} 2$ & 7.14 & 92.9 \\
\hline $\mathrm{K} 2 \mathrm{O}$ & 0.03 & 0.22 & $49.8 m$ & 4.01 & 85.4 & $31.3 \mathrm{~m} 2$ & 7.04 & 93.0 \\
\hline $\mathrm{Na} 2 \mathrm{O}$ & 0.88 & 6.41 & $42.9 m$ & 5.41 & 79.9 & $27 \mathrm{~m} 2$ & 7.14 & 92.9 \\
\hline $\mathrm{SO} 3$ & 3.32 & 24.27 & $37.1 \mathrm{~m}$ & 6.32 & 73.6 & $23.3 \mathrm{~m} 2$ & 7.30 & 92.7 \\
\hline $\mathrm{P2O5}$ & 0.00 & 0.00 & $32 m$ & 6.37 & 67.3 & $20.1 \mathrm{~m} 2$ & 6.40 & 93.6 \\
\hline $\mathrm{Cl}$ & & & $27.6 \mathrm{~m}$ & 5.98 & 61.3 & $17.4 \mathrm{~m} 2$ & 5.42 & 94.6 \\
\hline Undetermined & 0.19 & 1.38 & $23.8 \mathrm{~m}$ & 5.70 & 55.6 & $15 \mathrm{~m} 2$ & 5.60 & 94.4 \\
\hline Total & 13.69 & 100.0 & $20.5 \mathrm{~m}$ & 5.48 & 50.1 & $12.9 \mathrm{~m} 2$ & 6.12 & 93.9 \\
\hline \multicolumn{3}{|c|}{ Forms of Sulfur (\% dry fuel) } & $17.7 \mathrm{~m}$ & 5.33 & 44.8 & $11.1 \mathrm{~m} 2$ & 5.34 & 94.7 \\
\hline Pyritic & \multicolumn{2}{|c|}{0.47} & $15.3 \mathrm{~m}$ & 5.29 & 39.5 & $9.6 \mathrm{~m} 2$ & 4.64 & 95.4 \\
\hline Organic & \multicolumn{2}{|c|}{1.18} & $13.2 \mathrm{~m}$ & 4.99 & 34.5 & $8.3 \mathrm{~m} 2$ & 3.90 & 96.1 \\
\hline Sulfatic & \multicolumn{2}{|c|}{0.16} & $11.4 m$ & 4.64 & 29.8 & $7.2 \mathrm{~m} 2$ & 3.68 & 96.3 \\
\hline Fraction Free Silica & \multicolumn{2}{|l|}{0.10} & $9.8 \mathrm{~m}$ & 4.12 & 25.7 & $6.2 \mathrm{~m} 2$ & 3.64 & 96.4 \\
\hline Fraction Pyritic Iron & \multicolumn{2}{|l|}{0.37} & $8.5 \mathrm{~m}$ & 3.67 & 22.1 & $5.3 \mathrm{~m} 2$ & 3.10 & 96.9 \\
\hline \multicolumn{3}{|c|}{ Heating Value (Btu/nb, dry) } & $7.3 \mathrm{~m}$ & 3.38 & 18.7 & $4.8 \mathrm{~m} 2$ & 2.40 & 97.6 \\
\hline As Fired & 10040 & 7617 & $6.3 m$ & 3.31 & 15.4 & $4 m 2$ & 2.14 & 97.9 \\
\hline Dulong & 10003 & 7590 & $5.4 m$ & 3.18 & 12.2 & $3.4 \mathrm{~m} 2$ & 2.22 & 97.8 \\
\hline Acid Sol. Alkali (ppm) & Dry & As Rec'd & $4.7 \mathrm{~m}$ & 2.90 & 9.3 & $3 \mathrm{~m} 2$ & 2.06 & 97.9 \\
\hline $\mathrm{Na}$ & 7357 & 7357 & $4.1 \mathrm{~m}$ & 2.47 & 6.8 & $2.8 \mathrm{~m} 2$ & 0.74 & 99.3 \\
\hline $\mathrm{Mg}$ & 3321 & 3321 & $3.5 m$ & 1.82 & 5.0 & $2.2 \mathrm{~m} 2$ & 0.42 & 99.6 \\
\hline $\mathrm{Ca}$ & 14036 & 14036 & $3 m$ & 1.33 & 3.7 & $1.9 \mathrm{~m} 2$ & 0.00 & 100.0 \\
\hline $\mathbf{K}$ & 152 & 152 & $2.6 \mathrm{~m}$ & 1.11 & 2.6 & $1.6 \mathrm{~m} 2$ & 0.04 & 100.0 \\
\hline Fusion Temp. & ${ }^{\circ} \mathrm{F}$ & ${ }^{\circ} \mathrm{C}$ & $2.2 \mathrm{~m}$ & 0.91 & 1.6 & $1.4 \mathrm{~m} 2$ & 0.00 & 100.0 \\
\hline Reducing Conditions & \multirow{2}{*}{\multicolumn{8}{|c|}{ Size Statistics (Malvem Data Only) }} \\
\hline Initial Deformation & 2026 & 1108 & & & & & & \\
\hline Spherical & 2149 & 1176 & & & & & Malvern & All Data \\
\hline Hemispherical & 2175 & 1190 & Dv.5 & \multicolumn{3}{|c|}{ Volume Mean Diam. } & 18.46 & \\
\hline Fluid & 2191 & 1199 & Dv.9 & \multicolumn{3}{|c|}{$90 \%$ volume diameter } & 49.66 & \\
\hline Oxidizing Conditions & & & Dv.1 & \multicolumn{3}{|c|}{10 percentile volume diameter } & 4.44 & \\
\hline Initial Deformation & 2290 & 1255 & D4,3 & & & & 23.49 & \\
\hline Spherical & 2359 & 1293 & $\mathrm{D} 3,2$ & Sauter Me & Diameter & & 10.24 & \\
\hline Memispherical & 2365 & 1296 & Span & $\cdot$ & & & 2.35 & \\
\hline Fluid & 2388 & 1309 & Specific Sur & face Area & $(3 / \infty)$ & & 0.62 & \\
\hline
\end{tabular}

These Malvem data are for the -325 mesh size fractions. 
Table A.26 Summary of Properties of the Texas (San Miguel) Lignite.

\begin{tabular}{|c|c|c|c|c|c|c|c|c|}
\hline \multicolumn{9}{|c|}{\begin{tabular}{l|r} 
& Analyses \\
\end{tabular}} \\
\hline Proximate & Dry & As Rec'd & \multicolumn{2}{|c|}{ Size Distribution } & Sieves & \multicolumn{2}{|c|}{ mass $\%$ in size bin } & cum. mass \% \\
\hline Fixed Carbon & 17.51 & 14.27 & \multirow{3}{*}{\multicolumn{2}{|c|}{$\begin{array}{c}d p>600 \mu m \\
600 \mu m>d p>300 \mu m \\
300 \mu m>d p>149 \mu m\end{array}$}} & +28 & & 0.00 & 0.00 \\
\hline Volatile Matter & 30.41 & 24.78 & & & $28 \times 48$ & & 2.40 & 2.40 \\
\hline Moisture & \multicolumn{2}{|l|}{18.50} & & & $48 \times 100$ & & 9.83 & 12.23 \\
\hline Ultimate & Dry & As Rec'd & \multicolumn{2}{|c|}{$149 \mu m>d p>74 \mu m$} & $100 \times 200$ & & 18.28 & 30.50 \\
\hline$c$ & 29.43 & 23.99 & \multicolumn{2}{|c|}{$74 \mu m>d p>44 \mu m$} & $200 \times 325$ & & 17.23 & 47.73 \\
\hline$H$ & 3.20 & 2.61 & \multicolumn{2}{|c|}{$44 \mu m>d p$} & .325 & & 52.28 & 100.00 \\
\hline 0 & 12.95 & 10.55 & \multicolumn{3}{|c|}{ Size Distribution (Malvem) } & \multicolumn{3}{|c|}{ Size Distribution (Malvem) } \\
\hline $\mathrm{N}$ & 0.51 & 0.41 & \multirow{5}{*}{$\begin{array}{c}\text { Diameter } \\
(\mu \mathrm{m}) \\
188 \mathrm{~m} \\
162 \mathrm{~m} \\
140 \mathrm{~m}\end{array}$} & \multirow{2}{*}{ size bin } & \multirow{2}{*}{$\begin{array}{c}\text { cum. vol. } \\
\text { per. }\end{array}$} & \multirow{2}{*}{$\begin{array}{c}\text { Diameter } \\
(\mu \mathrm{m})\end{array}$} & \multirow{2}{*}{$\begin{array}{c}\% \text { in } \\
\text { size bin }\end{array}$} & cum. vol. \\
\hline$S$ & 1.75 & 1.43 & & & & & & per. \\
\hline $\mathrm{Cl}$ & 0.08 & 0.06 & & 0.00 & 100.0 & $118.4 \mathrm{~m} 2$ & 0.10 & 99.9 \\
\hline Ash & 52.18 & 42.53 & & 0.00 & 100.0 & $102.1 \mathrm{~m} 2$ & 0.35 & 99.7 \\
\hline Ash Chemistry & $\%$ dry fuel & $\%$ ash & & 0.00 & 100.0 & $88.1 \mathrm{~m} 2$ & 0.40 & 99.6 \\
\hline $\mathrm{SiO} 2$ & 34.36 & 65.85 & $121 \mathrm{~m}$ & 0.00 & 100.0 & $76 \mathrm{~m} 2$ & 0.35 & 99.7 \\
\hline $\mathrm{Al} 2 \mathrm{O} 3$ & 10.13 & 19.41 & $104 \mathrm{~m}$ & 0.00 & 100.0 & $65.6 \mathrm{~m} 2$ & 0.25 & 99.8 \\
\hline TIO2 & 0.45 & 0.87 & $89.9 m$ & 0.08 & 99.9 & $56.6 \mathrm{~m} 2$ & 1.80 & 98.2 \\
\hline $\mathrm{Fe} 2 \mathrm{O} 3$ & 0.87 & 1.66 & $77.5 \mathrm{~m}$ & 0.13 & 99.8 & $48.8 \mathrm{~m} 2$ & 4.90 & 95.1 \\
\hline $\mathrm{CaO}$ & 1.56 & 2.99 & $66.9 m$ & 0.15 & 99.6 & $42.1 \mathrm{~m} 2$ & 6.85 & 93.2 \\
\hline $\mathrm{MgO}$ & 0.25 & 0.48 & $57.7 m$ & 0.22 & 99.4 & $38.3 \mathrm{~m} 2$ & 7.55 & 92.5 \\
\hline $\mathrm{K} 2 \mathrm{O}$ & 0.98 & 1.88 & $49.8 m$ & 1.02 & 98.4 & $31.3 \mathrm{~m} 2$ & 7.50 & 92.5 \\
\hline $\mathrm{Na} 2 \mathrm{O}$ & 1.35 & 2.60 & $42.9 m$ & 2.78 & 95.6 & $27 m 2$ & 7.30 & 92.7 \\
\hline $\mathrm{SO} 3$ & 1.47 & 2.82 & $37.1 \mathrm{~m}$ & 4.85 & 90.8 & $23.3 \mathrm{~m} 2$ & 6.75 & 93.3 \\
\hline P2O5 & 0.00 & 0.01 & $32 m$ & 6.48 & 84.3 & $20.1 \mathrm{~m} 2$ & 6.05 & 94.0 \\
\hline $\mathrm{Cl}$ & 0.01 & 0.02 & $27.6 \mathrm{~m}$ & 6.97 & 77.3 & $17.4 \mathrm{~m} 2$ & 5.60 & 94.4 \\
\hline Undetermined & 0.74 & 1.42 & $23.8 \mathrm{~m}$ & 6.90 & 70.4 & $15 \mathrm{~m} 2$ & 5.60 & 94.4 \\
\hline Total & 52.17 & 100.0 & $20.5 m$ & 6.68 & 63.7 & $12.9 \mathrm{~m} 2$ & 5.55 & 94.5 \\
\hline Forms of Sulfur $(\%$ dry & & & $17.7 \mathrm{~m}$ & 6.70 & 57.0 & $11.1 \mathrm{~m} 2$ & 4.80 & 95.2 \\
\hline Pyritic & 0.29 & & $15.3 m$ & 6.73 & 50.3 & $9.6 \mathrm{~m} 2$ & 4.30 & 95.7 \\
\hline Organic & 1.35 & & $13.2 \mathrm{~m}$ & 6.45 & 43.8 & $8.3 \mathrm{~m} 2$ & 3.90 & 96.1 \\
\hline Sulfatic & 0.10 & & $11.4 \mathrm{~m}$ & 5.95 & 37.9 & $7.2 \mathrm{~m} 2$ & 3.55 & 96.5 \\
\hline Fraction Free Silica & 0.56 & & $9.8 \mathrm{~m}$ & 5.12 & 32.8 & $6.2 \mathrm{~m} 2$ & 3.30 & 96.7 \\
\hline Fraction Pyritic Iron & 0.41 & & $8.5 m$ & 4.45 & 28.3 & $5.3 \mathrm{~m} 2$ & 2.85 & 97.2 \\
\hline Heating Value (Btulb, & & & $7.3 m$ & 4.05 & 24.3 & $4.8 \mathrm{~m} 2$ & 2.40 & 97.6 \\
\hline As Fired & 5076 & 4137 & $6.3 m$ & 3.95 & 20.3 & $4 \mathrm{~m} 2$ & 2.20 & 97.8 \\
\hline Dutong & 5334 & 4347 & $5.4 m$ & 3.78 & 16.5 & $3.4 \mathrm{~m} 2$ & 2.10 & 97.9 \\
\hline Acid Sol. Alkali (ppm) & Dry & As Rec'd & $4.7 m$ & 3.42 & 13.1 & $3 m 2$ & 1.75 & 98.3 \\
\hline $\mathrm{Na}$ & 8788 & 8788 & $4.1 \mathrm{~m}$ & 2.88 & 10.2 & $2.8 \mathrm{~m} 2$ & 0.80 & 99.2 \\
\hline $\mathrm{Mg}$ & 1156 & 1156 & $3.5 \mathrm{~m}$ & 2.13 & 8.1 & $2.2 \mathrm{~m} 2$ & 0.60 & 99.4 \\
\hline $\mathrm{Ca}$ & 7628 & 7628 & $3 m$ & 1.58 & 6.5 & $1.9 \mathrm{~m} 2$ & 0.30 & 99.7 \\
\hline$k$ & 5862 & 5862 & $2.6 \mathrm{~m}$ & 1.37 & 5.2 & $1.6 \mathrm{~m} 2$ & 0.00 & 100.0 \\
\hline Fusion Temp. & of & ${ }^{\circ} \mathrm{C}$ & $2.2 m$ & 1.30 & 3.9 & $1.4 \mathrm{~m} 2$ & 0.10 & 99.9 \\
\hline Reducing Conditions & & & $1.9 \mathrm{~m}$ & 2.33 & 1.5 & $1.2 \mathrm{~m} 2$ & 0.10 & 99.9 \\
\hline Initial Deformation & 2349 & 1287 & & Size Statis & s (Malvern & Data Only) & & \\
\hline Spherical & 2458 & 1348 & & & & & Malvern & All Data \\
\hline Hemispherical & 2580 & 1416 & Dv.5 & Volume Me & n Diam. & & 14.76 & \\
\hline Fluid & 2759 & 1515 & Dv.9 & $90 \%$ volun & diameter & & 34.26 & \\
\hline Oxidizing Conditions & & & Dv.1 & 10 percenti & volume di & meter & 3.89 & \\
\hline Initial Deformation & 2338 & 1281 & D4,3 & & & & 17.45 & \\
\hline Spherical & 2433 & 1334 & D3,2 & Sauter Mea & Diameter & & 8.39 & \\
\hline Hemispherical & .2576 & 1413 & Span & & & & 2.06 & \\
\hline Fluid & 2762 & 1517 & Specific Su & face Area 1 & $(3 / \infty)$ & & 0.76 & \\
\hline
\end{tabular}

These Malvern data are for the -325 mesh size fractions. 
Table A.27 Summary of Properties of the Eastern Blend.

Eastern Blend

\begin{tabular}{|c|c|c|c|c|c|c|c|c|}
\hline Analyses & & & \multicolumn{3}{|c|}{ Analyses } & & & \\
\hline Proximate & Dry & As Rec'd & Size Distribur & ion & Sieves & \multicolumn{2}{|c|}{ mass $\%$ in size bin } & cum. mass $\%$ \\
\hline Fixed Carbon & 61.06 & 60.62 & \multirow{6}{*}{\multicolumn{2}{|c|}{$\begin{array}{c}d p>600 \mu \mathrm{m} \\
600 \mu \mathrm{m}>d p>300 \mu \mathrm{m} \\
300 \mu \mathrm{m}>d p>149 \mu \mathrm{m} \\
149 \mu \mathrm{m}>d p>74 \mu \mathrm{m} \\
74 \mu \mathrm{m}>d p>44 \mu \mathrm{m} \\
44 \mu \mathrm{m}>d p\end{array}$}} & +28 & \multirow{3}{*}{\multicolumn{2}{|c|}{$\begin{array}{l}0.00 \\
0.00 \\
1.30\end{array}$}} & 0.00 \\
\hline Volatile Matter & 30.27 & 30.05 & & & $28 \times 48$ & & & 0.00 \\
\hline Moisture & \multicolumn{2}{|l|}{0.72} & & & $48 \times 100$ & & & 1.30 \\
\hline Ultimate & Dry & As Rec'd & & & $100 \times 200$ & & 26.30 & $27: 60$ \\
\hline $\mathrm{C}$ & 77.95 & 77.39 & & & $200 \times 325$ & & 26.30 & 53.90 \\
\hline $\mathrm{H}$ & 4.79 & 4.76 & & & -325 & & 46.10 & 100.00 \\
\hline 0 & 5.51 & 5.47 & \multicolumn{3}{|c|}{ Size Distribution (Malvem) $)^{*}$} & \multicolumn{3}{|c|}{ Size Distribution (Malvem) } \\
\hline$N$ & 1.43 & 1.42 & \multirow{2}{*}{\multicolumn{2}{|c|}{\begin{tabular}{c|c}
$\begin{array}{c}\text { Diameter of in } \\
(\mu \mathrm{m})\end{array}$ & size bin \\
\end{tabular}}} & cum. vol. & \multirow{2}{*}{$\begin{array}{c}\text { Diameter } \\
(\mu \mathrm{m})\end{array}$} & \multirow{2}{*}{$\begin{array}{c}\% \text { in } \\
\text { size bin } \\
\end{array}$} & \multirow{2}{*}{$\begin{array}{c}\text { cum. vol. } \\
\text { per. }\end{array}$} \\
\hline S & 1.65 & 1.64 & & & per. & & & \\
\hline $\mathrm{Cl}$ & & & \multirow{3}{*}{$\begin{array}{l}188 \mathrm{~m} \\
162 \mathrm{~m} \\
140 \mathrm{~m}\end{array}$} & & & \multirow{3}{*}{$\begin{array}{l}118.4 \mathrm{~m} 2 \\
102.1 \mathrm{~m} 2\end{array}$} & & \\
\hline Ash & 8.67 & 8.61 & & & & & & \\
\hline Ash Chemistry & $\%$ dry fuel & $\%$ ash & & & & & & \\
\hline $\mathrm{SiO} 2$ & 4.25 & 49.03 & $121 \mathrm{~m}$ & & & $76 \mathrm{~m} 2$ & & \\
\hline $\mathrm{Al} 2 \mathrm{O} 3$ & 2.13 & 24.53 & $104 \mathrm{~m}$ & & & $65.6 \mathrm{~m} 2$ & & \\
\hline TIO2 & 0.09 & 1.00 & $89.9 m$ & & & $56.6 \mathrm{~m} 2$ & & \\
\hline $\mathrm{Fe} 2 \mathrm{O} 3$ & 1.48 & 17.03 & $77.5 \mathrm{~m}$ & & & $48.8 \mathrm{~m} 2$ & & \\
\hline $\mathrm{CaO}$ & 0.20 & 2.31 & $66.9 \mathrm{~m}$ & & & $42.1 \mathrm{~m} 2$ & & \\
\hline MgO & 0.07 & 0.86 & $57.7 m$ & & & $38.3 \mathrm{~m} 2$ & & \\
\hline $\mathrm{K} 2 \mathrm{O}$ & 0.17 & 1.99 & $49.8 m$ & & & $31.3 \mathrm{~m} 2$ & & \\
\hline $\mathrm{Na} 2 \mathrm{O}$ & 0.03 & 0.36 & $42.9 m$ & & & $27 \mathrm{~m} 2$ & & \\
\hline $\mathrm{SO} 3$ & 0.17 & 1.92 & $37.1 \mathrm{~m}$ & & & $23.3 \mathrm{~m} 2$ & & \\
\hline $\mathrm{P} 2 \mathrm{O} 5$ & 0.03 & 0.37 & $32 m$ & & & $20.1 \mathrm{~m} 2$ & & \\
\hline $\mathrm{Cl}$ & & & $27.6 \mathrm{~m}$ & & & $17.4 \mathrm{~m} 2$ & & \\
\hline Undetermined & 0.05 & 0.60 & $23.8 \mathrm{~m}$ & & & $15 \mathrm{~m} 2$ & & \\
\hline Total & 8.67 & 100.0 & $20.5 m$ & & & $12.9 \mathrm{~m} 2$ & & \\
\hline \multicolumn{3}{|c|}{ Forms of Sulfur ( $\%$ dry fuel) } & $17.7 \mathrm{~m}$ & & & $11.1 \mathrm{~m} 2$ & & \\
\hline Pyritic & \multicolumn{2}{|c|}{0.89} & $15.3 \mathrm{~m}$ & & & $9.6 \mathrm{~m} 2$ & & \\
\hline Organic & \multicolumn{2}{|c|}{0.75} & $13.2 \mathrm{~m}$ & & & $8.3 \mathrm{~m} 2$ & & \\
\hline Sulfatic & \multicolumn{2}{|c|}{0.01} & $11.4 \mathrm{~m}$ & & & $7.2 \mathrm{~m} 2$ & & \\
\hline Fraction Free Sillica & \multicolumn{2}{|c|}{0.25} & $9.8 \mathrm{~m}$ & & & $6.2 \mathrm{~m} 2$ & & \\
\hline Fraction Pyritic Iron & \multicolumn{2}{|c|}{0.75} & $8.5 \mathrm{~m}$ & & & $5.3 \mathrm{~m} 2$ & & \\
\hline Heating Value (Btu/lb, & & & $7.3 m$ & & & $4.8 \mathrm{~m} 2$ & & \\
\hline As Fired & 13933 & 13833 & $6.3 m$ & & & $4 \mathrm{~m} 2$ & & \\
\hline Dulong & & & $5.4 \mathrm{~m}$ & & & $3.4 \mathrm{~m} 2$ & & \\
\hline Acid Sol. Alkali (ppm) & Dry & As Rec'd & $4.7 m$ & & & $3 \mathrm{~m} 2$ & & \\
\hline $\mathrm{Na}$ & & & $4.1 \mathrm{~m}$ & & & $2.8 \mathrm{~m} 2$ & & \\
\hline $\mathrm{Mg}$ & & & $3.5 \mathrm{~m}$ & & & $2.2 \mathrm{~m} 2$ & & \\
\hline $\mathrm{Ca}$ & & & $3 m$ & & & $1.9 \mathrm{~m} 2$ & & \\
\hline$K$ & & & $2.6 m$ & & & $1.6 \mathrm{~m} 2$ & & \\
\hline Fusion Temp. & ${ }^{\circ} \mathrm{F}$ & ${ }^{\circ} \mathrm{C}$ & $2.2 \mathrm{~m}$ & & & $1.4 \mathrm{~m} 2$ & & \\
\hline Reducing Conditions & & & $1.9 \mathrm{~m}$ & & & $1.2 \mathrm{~m} 2$ & & \\
\hline Initial Deformation & 2133 & 1167 & & Size Sta & s (Malver & Data Only & & \\
\hline Spherical & 2429 & 1332 & & & & & Malvern & All Data \\
\hline Hemispherical & 2449 & 1343 & Dv.5 & Volume $A$ & n Diam. & & & \\
\hline Fluid & 2500 & 1371 & Dv.9 & $90 \%$ vole & diameter & & & \\
\hline Oxidizing Conditions & & & Dv.1 & 10 perce & volume $\mathrm{c}$ & meter & & \\
\hline Initial Deformation & 2497 & 1369 & $\mathrm{D} 4,3$ & & & & & \\
\hline Spherical & 2574 & 1412 & D3,2 & Sauter M & Diamete & & & \\
\hline Hemispherical & 2602 & 1428 & Span & & & & & \\
\hline Fluid & 2632 & 1444 & Specific Su & face Area & $1 / 3 / c c)$ & & & \\
\hline
\end{tabular}

These Malvem data are for the -325 mesh size fractions. 
Table A.28 Summary of Properties of the Pittsburgh \#8 - Decker Blend.

Pittsburgh \#8-Decker Blend

\begin{tabular}{|c|c|c|c|c|c|c|c|c|}
\hline \multirow{2}{*}{\begin{tabular}{|l} 
Analyses \\
Proximate \\
\end{tabular}} & & & \multicolumn{3}{|c|}{ Analyses } & \multirow{2}{*}{\multicolumn{2}{|c|}{ mass $\%$ in size bin }} & \multirow[b]{2}{*}{ cum mass : } \\
\hline & Dry & As Rec'd & \multicolumn{2}{|c|}{ Size Distribution } & Sieves & & & \\
\hline Fixed Carbon & 53.05 & 49.44 & \multirow{3}{*}{\multicolumn{2}{|c|}{$\begin{array}{c}d p>600 \mu \mathrm{m} \\
600 \mu m>d p>300 \mu m \\
300 \mu m>d p>149 \mu m\end{array}$}} & +28 & & 0.00 & 0.00 \\
\hline Volatile Matter & 41.23 & 38.42 & & & $28 \times 48$ & & 0.03 & 0.03 \\
\hline Moisture & \multicolumn{2}{|c|}{6.81} & & & $48 \times 100$ & & 2.83 & 2.87 \\
\hline Ultimate & Dry & As Rec'd & \multicolumn{2}{|c|}{$149 \mu m>d p>74 \mu m$} & $100 \times 200$ & & 25.53 & 28.40 \\
\hline C & 72.94 & 67.98 & \multicolumn{2}{|c|}{$74 \mu m>d p>44 \mu m$} & $200 \times 325$ & & 26.90 & 55.30 \\
\hline$H$ & 5.34 & 4.98 & \multicolumn{2}{|c|}{$44 \mu m>d p$} & -325 & & 44.73 & 100.03 \\
\hline 0 & 13.11 & 12.22 & \multicolumn{3}{|c|}{ Size Distribution (Malvem) } & \multicolumn{3}{|c|}{ Size Distribution (Malvem)* } \\
\hline$N$ & 1.28 & 1.19 & \multirow{5}{*}{$\begin{array}{c}\begin{array}{c}\text { Diameter } \\
(\mu \mathrm{m})\end{array} \\
188 \mathrm{~m} \\
162 \mathrm{~m} \\
140 \mathrm{~m}\end{array}$} & in & cum. vol. & Diameter & $\%$ in & cum. vol. \\
\hline$s$ & 1.04 & 0.97 & & size bin & per. & $(\mu \mathrm{m})$ & size bin & per. \\
\hline $\mathrm{Cl}$ & 0.07 & 0.06 & & 1.83 & 98.2 & $118.4 \mathrm{~m} 2$ & & \\
\hline Ash & 6.26 & 5.84 & & 4.39 & 93.8 & $102.1 \mathrm{~m} 2$ & & \\
\hline Ash Chemistry & $\%$ dry fuel & $\%$ ash & & 5.51 & 88.3 & $88.1 \mathrm{~m} 2$ & & \\
\hline $\mathrm{SiO} 2$ & 2.42 & 38.68 & $121 \mathrm{~m}$ & 5.36 & 82.9 & $76 \mathrm{~m} 2$ & & \\
\hline $\mathrm{Al} 2 \mathrm{O} 3$ & 1.29 & 20.56 & $104 m$ & 3.92 & 79.0 & $65.6 \mathrm{~m} 2$ & & \\
\hline TIO2 & 0.06 & 1.03 & $89.9 m$ & 2.77 & 76.2 & $56.6 \mathrm{~m} 2$ & & \\
\hline $\mathrm{Fe} 2 \mathrm{O} 3$ & 0.73 & 11.71 & $77.5 \mathrm{~m}$ & 3.74 & 72.5 & $48.8 \mathrm{~m} 2$ & & \\
\hline $\mathrm{CaO}$ & 0.48 & 7.67 & $66.9 m$ & 4.46 & 68.1 & $42.1 \mathrm{~m} 2$ & & \\
\hline MgO & 0.11 & 1.68 & $57.7 \mathrm{~m}$ & 4.80 & 63.3 & $38.3 \mathrm{~m} 2$ & & \\
\hline $\mathrm{K} 2 \mathrm{O}$ & 0.07 & 1.18 & $49.8 m$ & 5.54 & 57.7 & $31.3 \mathrm{~m} 2$ & & \\
\hline $\mathrm{Na} 2 \mathrm{O}$ & 0.21 & 3.38 & $42.9 \mathrm{~m}$ & 6.08 & 51.6 & $27 \mathrm{~m} 2$ & & \\
\hline 503 & 0.65 & 10.39 & $37.1 \mathrm{~m}$ & 7.15 & 44.5 & $23.3 \mathrm{~m} 2$ & & \\
\hline $\mathrm{P} 2 \mathrm{O} 5$ & 0.04 & 0.70 & $32 m$ & 6.53 & 38.0 & $20.1 \mathrm{~m} 2$ & & \\
\hline $\mathrm{Cl}$ & & & $27.6 m$ & 5.22 & 32.7 & $17.4 \mathrm{~m} 2$ & & \\
\hline Undetermined & 0.04 & 0.62 & $23.8 m$ & 4.18 & 28.6 & $15 \mathrm{~m} 2$ & & \\
\hline Total & 6.11 & 97.6 & $20.5 m$ & 3.63 & 24.9 & $12.9 \mathrm{~m} 2$ & & \\
\hline \multicolumn{3}{|c|}{ Forms of Sulfur (\% dry fuel) } & $17.7 \mathrm{~m}$ & 3.50 & 21.4 & $11.1 \mathrm{~m} 2$ & & \\
\hline Pyritic & \multicolumn{2}{|c|}{0.41} & $15.3 \mathrm{~m}$ & 3.51 & 17.9 & $9.6 \mathrm{~m} 2$ & & \\
\hline Organic & \multicolumn{2}{|l|}{0.61} & $13.2 \mathrm{~m}$ & 3.24 & 14.7 & $8.3 \mathrm{~m} 2$ & & \\
\hline Sulfatic & \multicolumn{2}{|c|}{0.08} & $11.4 \mathrm{~m}$ & 2.72 & 12.0 & $7.2 \mathrm{~m} 2$ & & \\
\hline Fraction Free Silica & \multirow{2}{*}{\multicolumn{2}{|c|}{$\begin{array}{l}0.20 \\
0.68\end{array}$}} & $9.8 \mathrm{~m}$ & 2.09 & 9.9 & $6.2 \mathrm{~m} 2$ & & \\
\hline Fraction Pyritic Iron & & & $8.5 m$ & 1.65 & 8.3 & $5.3 \mathrm{~m} 2$ & & \\
\hline Heating Value (Btu/lb, & & & $7.3 m$ & 1.46 & 6.8 & $4.8 \mathrm{~m} 2$ & & \\
\hline As Fired & 13357 & 12448 & $6.3 m$ & 1.40 & 5.4 & $4 m_{2}$ & & \\
\hline Dulong & 12948 & 12066 & $5.4 \mathrm{~m}$ & 1.34 & 4.1 & $3.4 \mathrm{~m} 2$ & & \\
\hline Acid Sol. Alkali (ppm) & Dry & As Rec'd & $4.7 \mathrm{~m}$ & 1.21 & 29 & $3 m 2$ & & \\
\hline $\mathrm{Na}$ & & & $4.1 \mathrm{~m}$ & 0.86 & 2.0 & $2.8 \mathrm{~m} 2$ & & \\
\hline Mg & & & $3.5 \mathrm{~m}$ & 0.67 & 1.3 & $2.2 \mathrm{~m} 2$ & & \\
\hline $\mathrm{Ca}$ & & & $3 m$ & 0.69 & 0.6 & $1.9 \mathrm{~m} 2$ & & \\
\hline$K$ & & & $2.6 \mathrm{~m}$ & 0.34 & 0.3 & $1.6 \mathrm{~m} 2$ & & \\
\hline Fusion Temp. & ${ }^{\circ} \mathrm{F}$ & ${ }^{\circ} \mathrm{C}$ & $2.2 m$ & 0.29 & 0.0 & $1.4 \mathrm{~m} 2$ & & \\
\hline Reducing Conditions & & & $1.9 \mathrm{~m}$ & 0.54 & -0.5 & $1.2 \mathrm{~m} 2$ & & \\
\hline Initial Deformation & 2139 & 1171 & & Size Stat & s (Malvert & Data Only) & & \\
\hline Spherical & 2201 & 1205 & & & & & Malvern & All Data \\
\hline Hemispherical & 2243 & 1228 & Dv.5 & Volume $N$ & Diam. & & 53.26 & \\
\hline Fluid & 2342 & 1283 & Dv.9 & $90 \%$ volu & diameter & & 80.51 & \\
\hline Oxidizing Conditions & & & Dv.1 & 10 percen & volume di & meter & 24.72 & \\
\hline Initial Deformation & 2319 & 1271 & $D 4,3$ & & & & 51.78 & \\
\hline Spherical & 2338 & 1281 & $\mathrm{D} 3,2$ & Sauter M & Diameter & & 24.84 & \\
\hline Hemispherical & 2388 & 1309 & Span & & & & 1.31 & \\
\hline Fluid & 2443 & 1339 & Specific Su & Iface Area & $(3 / c c)$ & & 0.33 & \\
\hline
\end{tabular}

"These Malvem data are for the -325 mesh size fractions. 
Table A.29 Summary of Properties of the NIPSCO Blend (1).

NIPSCO Blend (1)

\begin{tabular}{|c|c|c|c|c|c|c|c|c|}
\hline \multirow{2}{*}{\begin{tabular}{|l} 
Analyses \\
Proximate
\end{tabular}} & & & \multicolumn{3}{|c|}{ Analyses } & \multirow{2}{*}{\multicolumn{2}{|c|}{ mass $\%$ in size bin }} & \multirow[b]{2}{*}{ cum. mass $\%$} \\
\hline & Dry & As Rec'd & \multicolumn{2}{|c|}{ Size Distribution } & Sieves & & & \\
\hline Fixed Carbon & 48.70 & 44.13 & \multirow{3}{*}{\multicolumn{2}{|c|}{$\begin{array}{c}d p>600 \mu m \\
600 \mu m>d p>300 \mu m \\
300 \mu m>d p>149 \mu m\end{array}$}} & +28 & & 0.00 & 0.00 \\
\hline Volatile Matter & 43.51 & 39.43 & & & $28 \times 48$ & & 0.53 & 0.53 \\
\hline Moisture & \multicolumn{2}{|l|}{9.38} & & & $48 \times 100$ & & 8.60 & 9.13 \\
\hline Ultimate & Dry & As Rec'd & \multicolumn{2}{|c|}{$149 \mu m>d p>74 \mu m$} & $100 \times 200$ & & 28.87 & 38.00 \\
\hline $\mathrm{C}$ & 70.31 & 63.71 & \multicolumn{2}{|c|}{$74 \mu \mathrm{m}>\mathrm{dp}>44 \mu \mathrm{m}$} & $200 \times 325$ & & 19.67 & 57.67 \\
\hline $\mathrm{H}$ & 5.39 & 4.89 & \multicolumn{2}{|c|}{$44 \mu m>d p$} & -325 & & 42.33 & 100.00 \\
\hline o & 14.74 & 13.35 & \multicolumn{3}{|c|}{ Size Distribution (Malvem) } & \multicolumn{3}{|c|}{ Size Distribution (Malvern)" } \\
\hline$N$ & 1.22 & 1.10 & \multirow{5}{*}{$\begin{array}{c}\begin{array}{c}\text { Diameter } \\
(\mu \mathrm{m})\end{array} \\
188 \mathrm{~m} \\
162 \mathrm{~m} \\
140 \mathrm{~m}\end{array}$} & in & cum. vol. & Diameter & $\%$ in & cum. vol. \\
\hline$s$ & 0.53 & 0.48 & & size bin & per. & $(\mu \mathrm{m})$ & size bin & per. \\
\hline $\mathrm{Cl}$ & 0.06 & 0.05 & & 1.56 & 98.4 & $118.4 \mathrm{~m} 2$ & & \\
\hline Ash & 7.80 & 7.06 & & 3.84 & 94.6 & $102.1 \mathrm{~m} 2$ & & \\
\hline Ash Chemistry & $\%$ dry fuel & $\%$ ash & & 5.22 & 89.4 & $88.1 \mathrm{~m} 2$ & & \\
\hline $\mathrm{SiO} 2$ & 3.27 & 41.91 & $121 \mathrm{~m}$ & 5.92 & 83.5 & $76 \mathrm{~m} 2$ & & \\
\hline $\mathrm{Al} 2 \mathrm{O} 3$ & 1.68 & 21.54 & $104 \mathrm{~m}$ & 5.40 & 78.1 & $65.6 \mathrm{~m} 2$ & & \\
\hline $\mathrm{THO} 2$ & 0.10 & 1.32 & $89.9 m$ & 5.44 & 72.6 & $56.6 \mathrm{~m} 2$ & & \\
\hline $\mathrm{Fe} 2 \mathrm{O} 3$ & 0.37 & 4.79 & $77.5 \mathrm{~m}$ & 5.25 & 67.4 & $48.8 \mathrm{~m} 2$ & & \\
\hline $\mathrm{CaO}$ & 1.17 & 15.00 & $66.9 \mathrm{~m}$ & 5.10 & 62.3 & $42.1 \mathrm{~m} 2$ & & \\
\hline $\mathrm{MgO}$ & 0.20 & 2.61 & $57.7 \mathrm{~m}$ & 4.90 & 57.4 & $38.3 \mathrm{~m} 2$ & & \\
\hline $\mathrm{K} 2 \mathrm{O}$ & 0.09 & 1.17 & $49.8 m$ & 5.80 & 51.6 & $31.3 \mathrm{~m} 2$ & & \\
\hline $\mathrm{Na} 2 \mathrm{O}$ & 0.08 & 0.97 & $42.9 \mathrm{~m}$ & 6.16 & 45.4 & $27 \mathrm{~m} 2$ & & \\
\hline $\mathrm{SO} 3$ & 1.11 & 14.18 & $37.1 \mathrm{~m}$ & 6.47 & 38.9 & $23.3 \mathrm{~m} 2$ & & \\
\hline $\mathrm{P} 2 \mathrm{O5}$ & 0.05 & 0.69 & $32 m$ & 5.89 & 33.0 & $20.1 \mathrm{~m} 2$ & & \\
\hline $\mathrm{Cl}$ & & & $27.6 m$ & 4.49 & 28.5 & $17.4 \mathrm{~m} 2$ & & \\
\hline Undeterminod & 0.11 & 1.36 & $23.8 m$ & 3.58 & 25.0 & $15 \mathrm{~m} 2$ & & \\
\hline Total & 8.23 & 105.5 & $20.5 m$ & 3.54 & 21.4 & $12.9 \mathrm{~m} 2$ & & \\
\hline \multicolumn{3}{|c|}{ Forms of Sulfur ( $\%$ dry fue!) } & $17.7 \mathrm{~m}$ & 3.23 & 18.2 & $11.1 \mathrm{~m} 2$ & & \\
\hline Pyritic & \multicolumn{2}{|c|}{0.07} & $15.3 \mathrm{~m}$ & 3.00 & 15.2 & $9.6 m 2$ & & \\
\hline Organic & \multicolumn{2}{|c|}{0.49} & $13.2 \mathrm{~m}$ & 2.55 & 12.6 & $8.3 \mathrm{~m} 2$ & & \\
\hline Sulfatic & \multicolumn{2}{|c|}{0.00} & $11.4 m$ & 2.03 & 10.6 & $7.2 \mathrm{~m} 2$ & & \\
\hline Fraction Free Silica & \multicolumn{2}{|c|}{0.23} & $9.8 \mathrm{~m}$ & 1.60 & 9.0 & $6.2 \mathrm{~m} 2$ & & \\
\hline Fraction Pyritic Iron & 0.23 & & $8.5 \mathrm{~m}$ & 1.39 & 7.6 & $5.3 \mathrm{~m} 2$ & & \\
\hline Heating Value (Btunb, & & & $7.3 m$ & 1.26 & 6.4 & $4.8 \mathrm{~m} 2$ & & \\
\hline As Fired & 12979 & 11761 & $6.3 \mathrm{~m}$ & 1.22 & 5.1 & $4 \mathrm{~m} 2$ & & \\
\hline Dulong & 12451 & 11282 & $5.4 \mathrm{~m}$ & 1.15 & 4.0 & $3.4 \mathrm{~m} 2$ & & \\
\hline Acid Sol. Alkali (ppm) & Dry & As Rec'd & $4.7 \mathrm{~m}$ & 1.00 & 3.0 & $3 m 2$ & & \\
\hline $\mathrm{Na}$ & & & $4.1 \mathrm{~m}$ & 0.76 & 2.2 & $2.8 \mathrm{~m} 2$ & & \\
\hline $\mathrm{Mg}$ & & & $3.5 \mathrm{~m}$ & 0.60 & 1.6 & $2.2 \mathrm{~m} 2$ & & \\
\hline $\mathrm{Ca}$ & & & $3 m$ & 0.44 & 1.2 & $1.9 \mathrm{~m} 2$ & & \\
\hline$K$ & & & $2.6 \mathrm{~m}$ & 0.32 & 0.9 & $1.6 \mathrm{~m} 2$ & & \\
\hline Fusion Temp. & ${ }^{\circ} \mathrm{F}$ & ${ }^{\circ} \mathrm{C}$ & $2.2 \mathrm{~m}$ & 0.30 & 0.6 & $1.4 \mathrm{~m} 2$ & & \\
\hline Reducing Conditions & & & $1.9 \mathrm{~m}$ & 0.55 & 0.0 & $1.2 \mathrm{~m} 2$ & & \\
\hline Initial Deformation & 1513 & 823 & & Size Stati & s (Malven & Data Only) & & \\
\hline Spherical & 1549 & 843 & & & & & Malvern & All Data \\
\hline Hemispherical & 1610 & 877 & Dv. 5 & Volume $M$ & Diam. & & 143.33 & \\
\hline Fluid & 1673 & 912 & Dv.9 & $90 \%$ volu & diameter & & 84.47 & \\
\hline Oxidizing Conditions & & & Dv.1 & 10 percen & volume $\mathrm{d}$ & meter & 21.74 & \\
\hline Initial Deformation & 1554 & 846 & $D 4,3$ & & & & 54.68 & \\
\hline Spherical & 1579 & 860 & D3,2 & Sauter Me & Diameter & & 26.56 & \\
\hline Hemispherical & 1629 & 887 & Span & & & 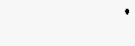 & 1.30 & \\
\hline Fluid & 1688 & 920 & Specific Su & face Area & $3 / c c)$ & & 0.30 & \\
\hline
\end{tabular}

These Malvern data are for the -325 mesh size fractions. 
Table A.30 Summary of Properties of the NIPSCO Blend (2).

NIPSCO Blend (2)

\begin{tabular}{|c|c|c|c|c|c|c|c|c|}
\hline \multirow{2}{*}{\begin{tabular}{|l|} 
Analyses \\
Proximate \\
\end{tabular}} & & & \multicolumn{3}{|c|}{ Analyses } & & & \\
\hline & Dry & As Fec'd & Size Distribut & tion & Sieves & \multicolumn{2}{|c|}{ mass $\%$ in size bin } & cum. mass $\%$ \\
\hline Fixed Carbon & 49.69 & 42.64 & \multirow{6}{*}{\multicolumn{2}{|c|}{$\begin{array}{c}d p>600 \mu m \\
600 \mu m>d p>300 \mu m \\
300 \mu m>d p>149 \mu m \\
149 \mu m>d p>74 \mu m \\
74 \mu m>d p>44 \mu m \\
44 \mu m>d p\end{array}$}} & +28 & & 0.00 & 0.00 \\
\hline Volatile Matter & 42.61 & 36.57 & & & $28 \times 48$ & & 0.35 & 0.35 \\
\hline Moisture & \multicolumn{2}{|c|}{14.17} & & & $48 \times 100$ & & 7.65 & 8.00 \\
\hline Ultimate & Dry & As Rec'd & & & $100 \times 200$ & & 21.90 & 29.90 \\
\hline C & 73.93 & 63.45 & & & $200 \times 325$ & & 19.85 & 49.75 \\
\hline$H$ & 4.96 & 4.25 & & & -325 & & 50.25 & 100.00 \\
\hline 0 & 11.70 & 10.04 & \multicolumn{3}{|c|}{ Size Distribution (Malvern)* } & \multicolumn{3}{|c|}{ Size Distribution (Malvern) $)^{\bullet}$} \\
\hline $\mathbf{N}$ & 1.06 & 0.91 & \multicolumn{2}{|c|}{ Diameter of in } & cum. vol. & \multirow{2}{*}{$\begin{array}{c}\text { Diameter } \\
(\mu \mathrm{m})\end{array}$} & \multirow{2}{*}{$\begin{array}{c}\% \text { in } \\
\text { size bin }\end{array}$} & \multirow{2}{*}{$\begin{array}{c}\text { cum. vol. } \\
\text { per. }\end{array}$} \\
\hline $\mathrm{S}$ & 0.59 & 0.51 & $(\mu \mathrm{m})$ & size bin & per. & & & \\
\hline $\mathrm{Cl}$ & 0.08 & 0.06 & $188 \mathrm{~m}$ & 0.00 & 100.0 & $118.4 \mathrm{~m} 2$ & & \\
\hline Ash & 7.71 & 6.61 & $162 \mathrm{~m}$ & 0.00 & 100.0 & $102.1 \mathrm{~m} 2$ & & \\
\hline Ash Chemistry & $\%$ dry fuel & $\%$ ash & $140 \mathrm{~m}$ & 0.00 & 100.0 & $88.1 \mathrm{~m} 2$ & & \\
\hline $\mathrm{SiO} 2$ & 2.99 & 38.84 & $121 \mathrm{~m}$ & 0.03 & 100.0 & $76 \mathrm{~m} 2$ & & \\
\hline $\mathrm{Al} 2 \mathrm{O} 3$ & 1.63 & 21.22 & $104 m$ & 0.00 & 100.0 & $65.6 \mathrm{~m} 2$ & & \\
\hline T1O2 & 0.10 & 1.27 & $89.9 m$ & 0.05 & 99.9 & $56.6 \mathrm{~m} 2$ & & \\
\hline $\mathrm{Fe} 2 \mathrm{O3}$ & 0.40 & 5.17 & $77.5 m$ & 0.50 & 99.4 & $48.8 \mathrm{~m} 2$ & & \\
\hline $\mathrm{CaO}$ & 0.93 & 12.13 & $66.9 m$ & 2.10 & 97.3 & $42.1 \mathrm{~m} 2$ & & \\
\hline $\mathrm{MgO}$ & 0.19 & 2.53 & $57.7 m$ & 4.90 & 92.4 & $38.3 \mathrm{~m} 2$ & & \\
\hline $\mathrm{K} 20$ & 0.10 & 1.35 & $49.8 m$ & 7.58 & 84.9 & $31.3 \mathrm{~m} 2$ & & \\
\hline $\mathrm{Na} 2 \mathrm{O}$ & 0.07 & 0.96 & $42.9 m$ & 8.45 & 76.4 & $27 m 2$ & & \\
\hline $\mathrm{SO} 3$ & 1.15 & 14.91 & $37.1 \mathrm{~m}$ & 8.33 & 68.1 & $23.3 \mathrm{~m} 2$ & & \\
\hline P2O5 & 0.06 & 0.76 & $32 m$ & 7.40 & 60.7 & $20.1 \mathrm{~m} 2$ & & \\
\hline $\mathrm{Cl}$ & & & $27.6 \mathrm{~m}$ & 6.30 & 54.4 & $17.4 \mathrm{~m} 2$ & & \\
\hline Undeterminod & 0.07 & 0.87 & $23.8 \mathrm{~m}$ & 5.75 & 48.6 & $15 \mathrm{~m} 2$ & & \\
\hline Total & 7.71 & 100.0 & $20.5 m$ & 5.60 & 43.0 & $12.9 \mathrm{~m} 2$ & & \\
\hline \multicolumn{3}{|c|}{ Forms of Sulfur ( $\%$ dry fuel) } & $17.7 \mathrm{~m}$ & 5.73 & 37.3 & $11.1 \mathrm{~m} 2$ & & \\
\hline Pyritic & \multicolumn{2}{|c|}{0.07} & $15.3 \mathrm{~m}$ & 5.50 & 31.8 & $9.6 \mathrm{~m} 2$ & & \\
\hline Organic & \multicolumn{2}{|c|}{0.53} & $13.2 \mathrm{~m}$ & 4.55 & 27.2 & $8.3 \mathrm{~m} 2$ & & \\
\hline Sulfatic & \multicolumn{2}{|c|}{0.00} & $11.4 \mathrm{~m}$ & 3.83 & 23.4 & $7.2 \mathrm{~m} 2$ & & \\
\hline Fraction Free Silica & \multicolumn{2}{|c|}{0.18} & $9.8 \mathrm{~m}$ & 3.35 & 20.1 & $6.2 \mathrm{~m} 2$ & & \\
\hline Fraction Pyritic Iron & \multicolumn{2}{|c|}{0.20} & $8.5 \mathrm{~m}$ & 3.08 & 17.0 & $5.3 \mathrm{~m} 2$ & & \\
\hline \multicolumn{3}{|c|}{ Heating Value (Btu/b, dry) } & $7.3 m$ & 2.90 & 14.1 & $4.8 \mathrm{~m} 2$ & & \\
\hline As Fired & 13821 & 11863 & $6.3 \mathrm{~m}$ & 2.73 & 11.4 & $4 \mathrm{~m} 2$ & & \\
\hline Dulong & 12942 & 11108 & $5.4 \mathrm{~m}$ & 2.43 & 8.9 & $3.4 \mathrm{~m} 2$ & & \\
\hline Acid Sol. Alkali (ppm) & Dry & As Rec'd & $4.7 m$ & 2.08 & 6.9 & $3 m 2$ & & \\
\hline $\mathrm{Na}$ & & & $4.1 \mathrm{~m}$ & 1.63 & 5.2 & $2.8 \mathrm{~m} 2$ & & \\
\hline $\mathrm{Mg}$ & & & $3.5 m$ & 1.23 & 4.0 & $2.2 \mathrm{~m} 2$ & & \\
\hline $\mathrm{Ca}$ & & & $3 m$ & 0.93 & 3.1 & $.9 \mathrm{~m} 2$ & & \\
\hline K & & & $2.6 \mathrm{~m}$ & 0.83 & 2.3 & $1.6 \mathrm{~m} 2$ & & \\
\hline Fusion Temp. & ${ }^{\circ} \mathrm{F}$ & ${ }^{\circ} \mathrm{C}$ & $2.2 m$ & 0.68 & 1.6 & $1.4 \mathrm{~m} 2$ & & \\
\hline Reducing Conditions & \multicolumn{8}{|c|}{$1.2 \mathrm{~m} 2$} \\
\hline Initial Deformation & 1147 & 619 & & Size Statis & s (Malver & Data Only) & & \\
\hline Spherical & 1174 & 634 & & & & & Malvern & All Data \\
\hline Hemispherical & 1207 & 653 & Dv.5 & Volume Me & Diam. & & 21.45 & \\
\hline Fluid & 1241 & 672 & Dv.9 & $90 \%$ volun & diameter & & 47.13 & \\
\hline Oxidizing Conditions & & & Dv.1 & 10 percent & volume $\mathrm{d}$ & meter & 5.05 & \\
\hline Initial Deformation & 1180 & 638 & D4,3 & & & & 24.28 & \\
\hline Spherical & 1194 & 645 & $\mathrm{D} 3,2$ & Sauter Me & Diameter & & 11.30 & \\
\hline Hemispherical & 1225 & 663 & Span & & & & 1.95 & \\
\hline Fluid & 1257 & 680 & Specific Sur & fface Area & $3 / \infty)$ & & 0.56 & \\
\hline
\end{tabular}

These Malvem data are for the -325 mesh size fractions. 
Table A.31 Summary of Properties of the Roland-Illinois \#6 Blend.

Roland/lllinois \#6 (2) Blend

\begin{tabular}{|c|c|c|c|c|c|c|c|c|}
\hline \multirow{2}{*}{\begin{tabular}{|l} 
Analyses \\
Proximate \\
\end{tabular}} & & & \multicolumn{3}{|c|}{ Analyses } & \multirow{2}{*}{\multicolumn{2}{|c|}{ mass $\%$ in size bin }} & \multirow[b]{2}{*}{ cum mass $\%$} \\
\hline & Dry & As Recid & \multicolumn{2}{|c|}{ Size Distribution } & Sieves & & & \\
\hline Fixed Carbon & 46.43 & 43.36 & \multirow{3}{*}{\multicolumn{2}{|c|}{$\begin{array}{c}d p>600 \mu m \\
600 \mu m>d p>300 \mu m \\
300 \mu m>d p>149 \mu m\end{array}$}} & +28 & & 0.00 & 0.00 \\
\hline Volatile Matter & 44.25 & 41.33 & & & $28 \times 48$ & & 0.27 & 0.27 \\
\hline Moisture & \multicolumn{2}{|c|}{6.60} & & & $48 \times 100$ & & 1.77 & 2.03 \\
\hline Ultimate & Dry & As Rec'd & \multicolumn{2}{|c|}{$149 \mu m>d p>74 \mu m$} & $100 \times 200$ & & 30.10 & 32.13 \\
\hline c & 68.58 & 64.06 & \multicolumn{2}{|c|}{$74 \mu m>d p>64 \mu m$} & $200 \times 325$ & & 28.70 & 60.83 \\
\hline$H$ & 4.73 & 4.42 & \multicolumn{2}{|c|}{$44 \mu m>d p$} & -325 & & 39.17 & 100.00 \\
\hline O & 14.70 & 13.73 & \multicolumn{3}{|c|}{ Size Distribution (Malvem) ${ }^{\bullet}$} & \multicolumn{3}{|c|}{ Size Distribution (Malvem) } \\
\hline$N$ & 1.09 & 1.02 & \multirow{5}{*}{$\begin{array}{l}\text { Diameter } \\
\frac{(\mu \mathrm{m})}{188 \mathrm{~m}} \\
162 \mathrm{~m} \\
140 \mathrm{~m}\end{array}$} & \multirow{2}{*}{$\begin{array}{l}\text { of in } \\
\text { size bin }\end{array}$} & cum. vol. & \multirow{2}{*}{$\begin{array}{c}\text { Diameter } \\
(\mu \mathrm{m})\end{array}$} & \multirow{2}{*}{$\begin{array}{c}\% \text { in } \\
\text { size bin }\end{array}$} & \multirow{2}{*}{$\begin{array}{c}\text { cum. vol. } \\
\text { per. }\end{array}$} \\
\hline $\mathrm{S}$ & 1.56 & 1.46 & & & per. & & & \\
\hline $\mathrm{Cl}$ & 0.03 & 0.03 & & 1.93 & 98.1 & $118.4 \mathrm{~m} 2$ & & \\
\hline Ash & 9.29 & 8.67 & & 4.75 & 93.3 & $102.1 \mathrm{~m} 2$ & & \\
\hline Ash Chemistry & $\%$ dry fuel & $\%$ ash & & 6.18 & 87.2 & $88.1 \mathrm{~m} 2$ & & \\
\hline $\mathrm{SiO} 2$ & 3.54 & 38.12 & $121 \mathrm{~m}$ & 6.74 & 80.4 & $76 \mathrm{~m} 2$ & & \\
\hline $\mathrm{Al} 2 \mathrm{O} 3$ & 1.49 & 16.04 & $104 m$ & 6.16 & 74.3 & $65.6 \mathrm{~m} 2$ & & \\
\hline THO2 & 0.09 & 0.95 & $89.9 m$ & 5.16 & 69.1 & $56.6 \mathrm{~m} 2$ & & \\
\hline $\mathrm{Fe} 2 \mathrm{O} 3$ & 1.12 & 12.01 & $77.5 \mathrm{~m}$ & 4.68 & 64.4 & $48.8 \mathrm{~m} 2$ & & \\
\hline $\mathrm{CaO}$ & 1.07 & 11.49 & $66.9 m$ & 5.14 & 59.3 & $42.1 \mathrm{~m} 2$ & & \\
\hline $\mathrm{MgO}$ & 0.27 & 2.94 & $57.7 \mathrm{~m}$ & 5.49 & 53.8 & $38.3 \mathrm{~m} 2$ & & \\
\hline $\mathrm{K} 2 \mathrm{O}$ & 0.11 & 1.16 & $49.8 m$ & 6.56 & 47.2 & $31.3 \mathrm{~m} 2$ & & \\
\hline $\mathrm{Na} 2 \mathrm{O}$ & 0.13 & 1.35 & $42.9 \mathrm{~m}$ & 6.57 & 40.7 & $27 \mathrm{~m} 2$ & & \\
\hline $\mathrm{SO} 3$ & 1.48 & 15.96 & $37.1 \mathrm{~m}$ & 6.14 & 34.5 & $23.3 \mathrm{~m} 2$ & & \\
\hline $\mathrm{P} 205$ & 0.06 & 0.64 & $32 \mathrm{~m}$ & 5.03 & 29.5 & $20.1 \mathrm{~m} 2$ & & \\
\hline $\mathrm{Cl}$ & & & $27.6 m$ & 3.56 & 25.9 & $17.4 \mathrm{~m} 2$ & & \\
\hline Undelermined & -0.06 & -0.65 & $.23 .8 m$ & 2.86 & 23.1 & $15 \mathrm{~m} 2$ & & \\
\hline Total & 9.29 & 100.0 & $20.5 \mathrm{~m}$ & 2.83 & 20.2 & $12.9 \mathrm{~m} 2$ & & \\
\hline \multicolumn{3}{|c|}{ Forms of Sulfur (\% dry fuel) } & $17.7 \mathrm{~m}$ & 2.83 & 17.4 & $11.1 \mathrm{~m} 2$ & & \\
\hline Pyritic & \multicolumn{2}{|c|}{0.58} & $15.3 \mathrm{~m}$ & 2.63 & 14.8 & $9.6 \mathrm{~m} 2$ & & \\
\hline Organic & 0.86 & & $13.2 \mathrm{~m}$ & 2.18 & 12.6 & $8.3 \mathrm{~m} 2$ & & \\
\hline Sulfatic & 0.06 & & $11.4 m$ & 1.75 & 10.9 & $7.2 \mathrm{~m} 2$ & & \\
\hline Fraction Free Silica & 0.36 & & $9.8 \mathrm{~m}$ & 1.46 & 9.4 & $6.2 \mathrm{~m} 2$ & & \\
\hline Fraction Pyritic Iron & 0.70 & & $8.5 \mathrm{~m}$ & 1.37 & 8.0 & $5.3 \mathrm{~m} 2$ & & \\
\hline Heating Value (Btu/lb, & & & $7.3 m$ & 1.33 & 6.7 & $4.8 \mathrm{~m} 2$ & & \\
\hline As Fired & 12752 & 11911 & $6.3 \mathrm{~m}$ & 1.31 & 5.4 & $4 m 2$ & & \\
\hline Dulong & 11835 & 11054 & $5.4 m$ & 1.23 & 4.2 & $3.4 \mathrm{~m} 2$ & & \\
\hline Acid Sol. Alkali (ppm) & Dry & As Rec'd & $4.7 \mathrm{~m}$ & 1.07 & 3.1 & $3 \mathrm{~m} 2$ & & \\
\hline $\mathrm{Na}$ & & & $4.1 \mathrm{~m}$ & 0.80 & 2.3 & $2.8 \mathrm{~m} 2$ & & \\
\hline $\mathrm{Mg}$ & & & $3.5 \mathrm{~m}$ & 0.68 & 1.6 & $2.2 \mathrm{~m} 2$ & & \\
\hline $\mathrm{Ca}$ & & & $3 m$ & 0.50 & 1.1 & $1.9 \mathrm{~m} 2$ & & \\
\hline$K$ & & & $2.6 \mathrm{~m}$ & 0.40 & 0.7 & $1.6 \mathrm{~m} 2$ & & \\
\hline Fusion Temp. & of & ${ }^{\circ} \mathrm{C}$ & $2.2 \mathrm{~m}$ & 0.34 & 0.4 & $1.4 \mathrm{~m} 2$ & & \\
\hline Reducing Conditions & & & $1.9 \mathrm{~m}$ & 0.53 & -0.1 & $1.2 \mathrm{~m} 2$ & & \\
\hline Initial Deformation & 2044 & 1118 & & Size Stat & s (Malverr & Data Only) & & \\
\hline Sphericàl & 2119 & 1160 & & & & & Malvern & All Data \\
\hline Hemispherical & 2195 & 1202 & Dv.5 & Volume $\mathrm{N}$ & Diam. & & 60.03 & \\
\hline Fluid & 2300 & 1260 & Dv.9 & $90 \%$ volu & diameter & & 88.28 & \\
\hline Oxidizing Conditions & & & Dv.1 & 10 percer & volume $\mathrm{d}$ & meter & 26.59 & \\
\hline Initial Deformation & 2181 & 1194 & D4,3 & & & & 58.48 & \\
\hline Spherical & 2208 & 1209 & D3,2 & Sauter M & Diameter & & 29.87 & \\
\hline Hemispherical & 2286 & 1252 & Span & & & & 1.26 & \\
\hline Fluid & 2378 & 1304 & Specific Su & Ifface Area & $3 / \infty)$ & & 0.30 & \\
\hline
\end{tabular}

These Malvern data are for the $-\mathbf{3 2 5}$ mesh size fractions. 
Table A.32 Summary of Properties of the Eagle Butte - Kentucky \#9 Blend.

Eagle Butte/Kentucky \#9 Blend

\begin{tabular}{|c|c|c|c|c|c|c|c|c|}
\hline Analyses & & & \multicolumn{3}{|c|}{ Analyses. } & & & \\
\hline Proximate & Dry & As Rec'd & Size Distribu & ution & Sieves & \multicolumn{2}{|c|}{ mass \% in size bin } & cum. mass $\%$ \\
\hline Fixed Carbon & 46.53 & 37.12 & \multirow{3}{*}{\multicolumn{2}{|c|}{$\begin{array}{c}d p>600 \mu \mathrm{m} \\
600 \mu \mathrm{m}>d p>300 \mu \mathrm{m} \\
300 \mu \mathrm{m}>d p>149 \mu \mathrm{m}\end{array}$}} & +28 & \multicolumn{2}{|c|}{0.00} & 0.00 \\
\hline Volatile Matter & 43.90 & 35.02 & & & $28 \times 48$ & & 0.00 & 0.00 \\
\hline Moisture & \multicolumn{2}{|c|}{20.23} & & & $48 \times 100$ & & 8.00 & 8.00 \\
\hline Uitimate & Dry & As Recid & \multicolumn{2}{|c|}{$149 \mu \mathrm{m}>d p>74 \mu \mathrm{m}$} & $100 \times 200$ & & 21.50 & 29.50 \\
\hline C & 68.32 & 54.50 & \multicolumn{2}{|c|}{$74 \mu \mathrm{m}>\mathrm{dp}>44 \mu \mathrm{m}$} & $200 \times 325$ & & 18.60 & 48.10 \\
\hline$H$ & 4.76 & 3.80 & \multicolumn{2}{|c|}{$44 \mu m \times d p$} & -325 & & 51.90 & 100.00 \\
\hline 0 & 14.50 & 11.57 & \multicolumn{3}{|c|}{ Size Distribution (Malvern)" } & \multicolumn{3}{|c|}{ Size Distribution (Malvem) } \\
\hline $\mathbf{N}$ & 1.11 & 0.89 & \multirow{5}{*}{$\begin{array}{c}\text { Diameter } \\
(\mu \mathrm{m})\end{array}$} & \multirow{2}{*}{$\int_{\text {size bin }}$} & cum. vol. & \multirow{2}{*}{$\begin{array}{c}\text { Diameter } \\
(\mu \mathrm{m})\end{array}$} & \multirow{2}{*}{$\begin{array}{c}\% \text { in } \\
\text { size bin } \\
\end{array}$} & \multirow{2}{*}{$\begin{array}{c}\text { cum. vol. } \\
\text { per. }\end{array}$} \\
\hline S & 1.74 & 1.39 & & & per. & & & \\
\hline $\mathrm{Cl}$ & 0.00 & 0.00 & & 0.00 & 100.0 & $118.4 \mathrm{~m} 2$ & & \\
\hline Ash & 8.91 & 7.11 & & 0.00 & 100.0 & $102.1 \mathrm{~m} 2$ & & \\
\hline Ash Chemistry & $\%$ dry fuel & $\%$ ash & & 0.05 & 100.0 & $88.1 \mathrm{~m} 2$ & & \\
\hline $\mathrm{SiO} 2$ & 2.63 & 29.55 & $121 \mathrm{~m}$ & 0.05 & 99.9 & $76 \mathrm{~m} 2$ & & \\
\hline $\mathrm{Al} 2 \mathrm{O} 3$ & 1.29 & 14.44 & $104 \mathrm{~m}$ & 0.05 & 99.9 & $65.6 \mathrm{~m} 2$ & & \\
\hline THO2 & 0.09 & 1.01 & $89.9 m$ & 0.05 & 99.8 & $56.6 \mathrm{~m} 2$ & & \\
\hline $\mathrm{Fe} 2 \mathrm{O} 3$ & 1.21 & 13.57 & $77.5 m$ & 0.15 & 99.7 & $48.8 \mathrm{~m} 2$ & & \\
\hline $\mathrm{CaO}$ & 1.31 & 14.70 & $66.9 \mathrm{~m}$ & 1.15 & 98.5 & $42.1 \mathrm{~m} 2$ & & \\
\hline MgO & 0.32 & 3.54 & $57.7 \mathrm{~m}$ & 3.10 & 95.4 & $38.3 \mathrm{~m} 2$ & & \\
\hline $\mathrm{K} 2 \mathrm{O}$ & 0.10 & 1.12 & $49.8 \mathrm{~m}$ & 6.10 & 89.3 & $31.3 \mathrm{~m} 2$ & & \\
\hline $\mathrm{Na} 2 \mathrm{O}$ & 0.11 & 1.27 & $42.9 \mathrm{~m}$ & 8.80 & 80.5 & $27 m_{2}$ & & \\
\hline $\mathrm{SO} 3$ & 1.84 & 20.67 & $37.1 \mathrm{~m}$ & 9.25 & 71.3 & $23.3 \mathrm{~m} 2$ & & \\
\hline $\mathrm{P} 2 \mathrm{OS}$ & 0.02 & 0.28 & $32 m$ & 8.60 & 62.7 & $20.1 \mathrm{~m} 2$ & & \\
\hline $\mathrm{Cl}$ & & & $27.6 m$ & 7.15 & 55.5 & $17.4 \mathrm{~m} 2$ & & \\
\hline Undetermined & 0.01 & 0.08 & $23.8 \mathrm{~m}$ & 5.70 & 49.8 & $15 \mathrm{~m} 2$ & & \\
\hline Total & 8.93 & 100.2 & $20.5 m$ & 5.50 & 44.3 & $12.9 \mathrm{~m} 2$ & & \\
\hline \multicolumn{3}{|c|}{ Forms of Sulfur ( $\%$ dry fuel) } & $17.7 \mathrm{~m}$ & 5.85 & 38.5 & $11.1 \mathrm{~m} 2$ & & \\
\hline Pyritic & \multicolumn{2}{|c|}{0.55} & $15.3 m$ & 5.70 & 32.8 & $9.6 \mathrm{~m} 2$ & $\cdot$ & \\
\hline Organic & \multicolumn{2}{|c|}{0.88} & $13.2 \mathrm{~m}$ & 5.20 & 27.6 & $8.3 \mathrm{~m} 2$ & & \\
\hline Sulfatic & \multicolumn{2}{|c|}{0.31} & $11.4 \mathrm{~m}$ & 4.25 & 23.3 & $7.2 \mathrm{~m} 2$ & & \\
\hline Fraction Free Silica & 0.26 & & $9.8 \mathrm{~m}$ & 3.60 & 19.7 & $6.2 \mathrm{~m} 2$ & & \\
\hline Fraction Pyritic Iron & 0.49 & & $8.5 m$ & 3.25 & 16.5 & $5.3 \mathrm{~m} 2$ & & \\
\hline Heating Value (Btu/lb, & & & $7.3 \mathrm{~m}$ & 2.95 & 13.5 & $4.8 \mathrm{~m} 2$ & & \\
\hline As Fired & 11876 & 9473 & $6.3 m$ & 2.70 & 10.8 & $4 \mathrm{~m} 2$ & & \\
\hline Dulong & 11835 & 9441 & $5.4 m$ & 2.40 & 8.4 & $3.4 \mathrm{~m} 2$ & & \\
\hline Acid Sol. Alkali (ppm) & Dry & As Rec'd & $4.7 m$ & 2.10 & 6.3 & $3 m 2$ & & \\
\hline $\mathrm{Na}$ & & & $4.1 \mathrm{~m}$ & 1.90 & 4.4 & $2.8 \mathrm{~m} 2$ & & \\
\hline $\mathrm{Mg}$ & & & $3.5 \mathrm{~m}$ & 1.30 & 3.1 & $2.2 \mathrm{~m} 2$ & & \\
\hline $\mathrm{Ca}$ & & & $3 m$ & 1.10 & 2.0 & $1.9 \mathrm{~m} 2$ & & \\
\hline $\mathrm{K}$ & & & $2.6 \mathrm{~m}$ & 0.70 & 1.3 & $1.6 \mathrm{~m} 2$ & & \\
\hline Fusion Temp. & ${ }^{\circ} \mathrm{F}$ & $\infty$ & $2.2 \mathrm{~m}$ & 0.45 & 0.9 & $1.4 \mathrm{~m} 2$ & & \\
\hline Reducing Conditions & & & $1.9 \mathrm{~m}$ & 0.30 & 0.6 & $1.2 \mathrm{~m} 2$ & & \\
\hline Initial Deformation & 1999 & 1093 & & Size Statis & s (Malverr & Data Oniy) & & \\
\hline Spherical & 2106 & 1152 & & & & & Malvern & All Data \\
\hline Hemispherical & 2142 & 1172 & Dv. 5 & Volume Me & Diam. & & 23.90 & \\
\hline Fluid & 2233 & 1223 & Dv.9 & $90 \%$ volur & diameter & & 50.60 & \\
\hline Oxidizing Conditions & & & Dv.1 & 10 percent & volume di & meter & 6.00 & \\
\hline Initial Deformation & 2188 & 1198 & D4,3 & & & & 27.15 & \\
\hline Spherical & 2212 & 1211 & D3,2 & Sauter Me & Diameter & & 13.45 & \\
\hline Hemispherical & 2239 & 1226 & Span & & & & 1.85 & \\
\hline Fluid & 2320 & 1271. & Specific Su & iface Area & $3 / \infty)$ & & 0.45 & \\
\hline
\end{tabular}

These Malvern data are for the -325 mesh size fractions. 


\section{INITIAL DISTRIBUTION}

Dr. Ralph Carabetta

Project Management

U.S. DOE/PETC

P.O. Box 10940

Pittsburgh, PA 15236-0940

Ms. Kay Downey

MS 58-M217

U.S. DOE/PETC

P.O. Box 10940

Pittsburgh, PA 15236-0940

Mr. James M. Ekmann

Director, Coal Combustion Division

U.S. DOE/PETC

P.O. Box 10940, MS 84-307

Pittsburgh, PA 15241

Dr. David Beecy, Director

Office of Advanced Research

Fossil Energy, FE-72

U.S. DOE/GTN

19901 Germantown Road

Germantown, MD 20585

Mr. Robert Wright

Office of Advanced Research

Fossil Energy, FE-72

U.S. DOE/GTN

19901 Germantown Road

Germantown, MD 20585

Mr. Philip M. Goldberg

Coal Utilization Division

U.S. DOE/PETC, 922-H

P.O. Box 10940

Pittsburgh, PA 15236-0940

Mr. James Hickerson

Coal Utilization Division

U.S. DOE/PETC, 922-H

P.O. Box 10940

Pittsbrugh, PA 15236-0940

Dr. Larry Ruth

Coal Utilization Division

U.S. DOE/PETC

P.O. Box 10940

Pittsburgh, PA 15236-0940
Mr. Cliff Smith

Coal Utilization Division

U.S. DOE/PETC, 922-H

P.O. Box 10940

Pittsbrugh, PA 15236-0940

Mr. James Jovanovich

PM-01, MS922-206

U.S. DOE/PETC, 922-H

P.O. Box 10940

Pittsburgh, PA 15236-0940

Mr. Laurance L. Oden

Albany Research Facility, Bureau of Mines

U.S. Department of the Interior

Albany, OR 97321

Professor János Beér

Massachusetts Institute of Tech.

Department of Chemical Engineering

66-552

Cambridge, MA 02139

Professor Robert Essenhigh

Mechanical Engineering Department

Ohio State University

206 West 18th Avenue

Columbus, $\mathrm{OH} 43210$

Professor Thomas H. Fletcher

Chemical Engineering Department

Brigham Young University

$350 \mathrm{CB}$

Provo, UT 84602

Professor Robert Hurt

Division of Engineering, Box D

Brown University

Providence, RI 02912

Professor Bryan M. Jenkins

University of California, Davis

Biological and Ag. Eng. Dpt.

Davis, CA 95616-5294

Dr. Michael L. Jones

Energy and Mineral Research Center

University of North Dakota

Box 8213, University Station

Grand Forks, ND 58202

Attn: Dr. Steve Benson 
Professor John P. Longwell

Chemical Engineering Department

Massachusetts Institute of Technology

Room 66554

Cambridge, MA 02139

Professor Reginald E. Mitchell

High Temperature Gasdynamics Lab

Stanford University

Mechanical Engineering Department

Palo Alto, CA 94305

Professor Ronald Pugmire

Vice President for Research

University of Utah

210 Park Building

Salt Lake City, UT 84112

Professor Daniel E. Rosner

Director, High Temperature Chem Engr Lab

Yale University

P.O. Box 2159

New Haven, CT 06520-8167

Professor Adel Sarofim

Department of Chemical Engineering

Massachusetts Institute of Technology

66-466

Cambridge, MA 02139

Professor Philip Smith

Department of Chemical Engineering

University of Utah

2250 Merrill Engineering Bldg

Salt Lake City, UT 84112

Professor Terry Wall

Department of Chemical \& Materials Engr.

The University of Newcastle

Newcastle, NSW 2308

Australia

Professor Jost Wendt

Department of Chemical Engineering

University of Arizona

Tuscon, AZ 85721

Dr. Seymour B. Alpert

P.O. Box 10412

Electric Power Research Institute

3412 Hillview Avenue

Palo Alto, CA 94308
Dr. Richard Bain, Manager

Biomass Power Program

National Renewable Energy Laboratory

1617 Cole Boulevard

Golden, CO 80401-3393

Mr. Richard W. Borio

Combustion Engineering Inc.

1000 Prospect Hill Road, P.O. Box 500

Windsor, CT 06095

Attn: Mr. Michael Hargrove

Chester M. Bowling

Manager Tech. Support \& Mrktng

ARCO Coal Company

555 Seventeenth St.

Denver, CO 80202

Mr. Richard W. DeSollar

Fuels Coordinator

Central Illinois Public Service Co.

607 East Adams Street

Springfield, Il 62701

Mr. Larry Dora

Engineering Supervisor

Northern Indiana Public Service Co.

P.O. Box M-720

Gary, IN 46401

Dr. Woodrow Fiveland, Supervisor

Heat Transfer \& Fluid Mechanics Section

Babcock \& Wilcox

1562 Beeson St.

Alliance, $\mathrm{OH} 44601$

Dr. J. Peter Gorog

Research and Development

Pulp, Paper and Packaging

Weyerhaeuser Company

WTC $2 \mathrm{H} 22$

Tacoma, WA 98477

Mr. Peter Torslev Jensen

ELSAM

Fuel Department

DK-7000 Fredericia

Denmark

Dr. Flynt Kennedy, Vice President

Research \& Development

Consolidation Coal Co.

4000 Brownsville Road

Library, PA 15129

Attn: Dr. Anthony Fonseca 
Dr. John Lytle

Mineral Engineering Laboratory

Illinois State Geological Survey

Oak and Gregory Sts.

Champaign, $\mathrm{IL} 61820$

Dr. John S. Maulbetsch

Exploratory Research

EPRI

3412 Hillview Avenue

Palo Alto, CA 94303

Dr. Arun K. Mehta

P.O. Box 10412

Electric Power Research Institute

3412 Hillview Avenue

Palo Alto, CA 94308

Mr. Thomas R. Miles

Consulting Design Engineer

5475 SW Arrowwood Lane

Portland, OR 97225

Dr. Thomas Milne

National Renewable Energy Laboratory

1617 Cole Boulevard

Golden, CO 80401-3393

Dr. Ralph P. Overend

National Renewable Energy Lab

1617 Cole Boulevard

Golden, CO 80401-3393

Mr. Eric H. Reichl

P.O. Box 472

Princeton, NJ 08542

Dr. Dan Seery

United Technologies Research Center

Combustion Sciences

Silver Lane, MS 30

East Hartford, CT 06108

Mr. Ian W. Smith, Manager

Coal Utilization Program

CSIRO

51 Delhi Road, P.O. Box 136

North Ryde, NSW, 2113

Australia

Professor L. Douglas Smoot

Consulting Design Engineer

5475 SW Arrowwood Lane

Portland, OR 97225
Mr. Jerry Sullivan

Project Director

PSI Energy

1000 East Main Street

Plainfield, IN 46168

Dr. David A. Tillman

Foster Wheeler Environmental Corporation

2525 Natomas Park Drive, Suite 250

Sacramento, CA 95833-2900

Mr. Stanley Vecci, Director

Energy Systems Lab/Research Dev Div

Babcock \& Wilcox

1562 Beeson Street

Alliance, $\mathrm{OH} 44601$

Attn: Mr. John Berthold

Mr. Thomas Morris

Mr. Larry Rodgers

Dr. Hamid Sarv

Mr. James Warchol

Mr. Ralph Bailey

Mr. George Farthing

Mr. Ben Ziesmer

Fuel Coordinator

Northern Indiana Public Services Co.

5265 Hohman Ave.

Hammond, IN 46320

MS0701 R.W. Lynch, 6100

MS0735 D.E. Arvizu, 6200

Attn: $\quad 6211$ G.A. Carlson

6212 H.R. Stephens

6203 A.P. Sylwester

MS0704 P.C. Klimas, 6201

Attn: $\quad 6215$ J. Chavez

6215 K.S. Rawlinson

MS9001 J.C. Crawford, 8000

Attn: $\quad 8100$ M.E. John

8113 J.C. Swearengen

8700 R.C. Wayne

8713 J.F.C. Wang

8713 D.K. Ottesen

8714 M. Perra

MS9054 W.J. McLean, 8300

Attn: $\quad 8302$ W. Bauer 8351 L.A. Rahn

8304 K. Wilson 8353 F.P. Tully

8341 W. Wolfer 8355 G.A. Fisk

8342 R. Stulen 8362 R.W. Carling

8347 A. Pontau 8366 C.M. Hartwig 
MS9052 A.J. Akanetuk, 8361

MS9052 L.L. Baxter, 8361

MS9052 D.R. Hardesty, 8361 (15)

MS9052 T. Linsmeyer, 8361

MS9052 J.R. Ross, 8361

MS9052 G. Sclippa, 8361

MS9052 S. Sinquefield, 8361

MS9402 N.Y.C. Yang, 8714

MS9021 Technical Communications Department, 8535 for OSTI (10)

MS9021 Technical Communications Department, 8535

Technical Library, MS0899, 13414

MS0899 Technical Library, 13414 (4)

MS9018 Central Technical Files, 8523-2 (3) 